\title{
Las Memorias del Conde de Robres: la nueva planta y la narrativa de la guerra civil
}

\author{
José María IñurRiteguI Rodríguez *
}

\begin{abstract}
RESUMEN
Mediante un completo análisis de la narrativa de la guerra civil, este trabajo propone una revisión de la obra de Alberto López de Mendoza, III Conde de Robres. Ante todo, en las Memorias para la historia de las guerras de España se descubre un observatorio privilegiado que no sólo permite examinar las diferentes variantes de la narrativa de la guerra civil, sino también esbozar la difícil coexistencia entre la política y la historia en el momento inaugural del Setecientos hispano.

ABSTRACT

Trough a complete analysis of the narrative of the civil war, this article postulates a revision of the work of Alberto López de Mendoza, III Conde de Robres. First of all, the Memorias para la historia de las guerras civiles de España is a priviledge scene to examine the various faces of the narrative of the civil war and the difficult coexistence between politic and history in the spanish early eighteenth century.
\end{abstract}

I. En las entrañas de la traumática contienda civil del amanecer del Setecientos hispano el Conde de Robres, Agustín López de Mendoza y Pons, encuentra el momento adecuado para el sutil y delicado cultivo de la memoria histórica. La participación política activa de un noble aragonés de filiación borbónica en el certamen sucesorio desemboca en la primavera de 1708 en la composición de unas atípicas Memorias que elocuentemente se dicen para servir a la historia de las guerras civiles

* UNED. 
de España ${ }^{1}$. La propia operatividad pretendida por el autor para su texto, y la profunda reformulación del sentido moral y político del valor didáctico de la historia que destila, convierten esas páginas en una pieza ciertamente singular en el complejo panorama de la narrativa de la guerra civil $^{2}$. Frente al uso político común de la historiografía en el turbulento teatro de la confrontación dinástica y civil, la glosa laudatoria de las glorias del monarca, las Memorias asumian ya por principio el inusual empeño de arrojar luz y levantar acta sobre las causas de fondo que motivan el desastre del encuentro doméstico. Apegadas en todo momento a la más pura y feroz dimensión civil del combate y a su más honda esencia política, siempre fieles al preciso estímulo al que responde la opción misma de la escritura, las Memorias forjan sobre esa peculiar mirada una acusada personalidad narrativa y política con novedades de subido valor en su género y en su contexto.

Pronunciamientos tempranos del propio autor ya revelan al lector la infrecuente posición desde la que se escribe. Nada quizás evidencia mejor el particular abordaje de la materia, ni el talante con el que se asume la escritura, como la consideración que en las Memorias se otorga al laberinto jurídico de los derechos dinásticos. El orden de prelación de los derechos propios de unas Casas sobre la corona católica, motivo y materia de multitud de sondeos políticos en ese momento inaugural del Setecientos, tan sólo merece en las Memorias una escueta y aséptica reseña de la concurrencia de interpretaciones dinásticas contrapuestas e irreconciliables. El universo semántico que teje la urdimbre argumental de la Alegación jurídica de Alejandro de Herrera o el Memorial histórico y político de

BHA 2001-0176. CONDE DE ROBRES, Memorias para la historia de las guerras civiles de España, Biblioteca de Cataluña (BC), Manuscritos (Mss.), n. 151. Las citas proceden de la única edición del texto, la preparada por Baldomero Mediano y Ruiz para la Biblioteca de Escritores Aragoneses (Zaragoza, Diputación Provincial de Zaragoza, 1882). Para la fecha de composición de la obra, cfr., págs. 62 y 380 . Sobre la acusada impronta cívica de la escritura de un cierto género de memorias y diarios, y así para su inequivoca vinculación con la vida política activa y la de cidida implicación en los asuntos de la respublica, cfr., AmELANG, J., "El mundo mental de Jeroni Pujades", en Kagan, R.L. y PARKer, G. (edts.), España, Europa y el mundo atlántico. Madrid, Marcia! Pons, 2001, págs. 279/297, y del mismo, The Flight of lcarus. Artisans autobiography in early modern Europe. Stantord UP, 1998.

2 Para una inicial fijación de la posición que corresponde a las Memorias en el cuadro de la narrativa de la guerra civil, cfr., STIFFONI. G., Verita della storia e ragione del potere nella Spagna del primo'700. Milán, Franco Angeli, 1989, págs. 57/110; GaRCía CARCEL, R., Felipe $V$ y los españoles. Barcelona, Plaza y Janes, 2002, págs. 150/161, y GimÉnEz, E., “Felipe $V$ y la nueva planta en la Corona de Aragón", en Fernandez Garcia, J., Bel Bravo, M. a A., y Delgado, J.M. (edts.), El cambio dinástico y sus repercusiones en la España del siglo xvill. Universidad de Jaén, 2001. págs. $37 / 38$. 
Benito de la Soledad, el pulso conceptual del Manifiesto de Leibniz o la Défense del droit de la Maison d'Autriche de Francois Paul de Lisola, el meticuloso escrutinio y exégesis que todos ellos y muchos más emprenden de unas leyes fundamentales por fundacionales de la monarquia y de unas leyes federales cuya raíz etimológica, foedus, condensa la dimensión europea del debate, son así signos tan propios del tiempo como ajenos al estilo y al léxico de las Memorias ${ }^{3}$.

No es algo casual. En realidad ninguno de los argumentos capitales que vestían el magno debate de la fidelidad conforman la indumentaria de las Memorias ${ }^{4}$. Su prudente silencio frente a los poderosos ecos procedentes de las proclamas que descubren bajo la cuestión sucesoria una auténtica guerra de religión es otro rasgo acusado de su distinción y distancia frente al canon común de la literatura política de la guerra civil ${ }^{5}$. Y lo mismo pu-

3 Ctr., Alejandro de Herrera, Alegación juridica en que por las verdades más sólidas de la jurisprudencia se muestra el infalible derecho con que los Reinos y Señoríos de España pertenecen por muerte del Rey Católico Carlos II al serenisimo Señor Archiduque de Austria Carlos III, verdadero y legítimo Rey de España. Lisboa, Valentín de Acosta Deslandes, 1704; Fray Benito de la SOledAD, Memorial histórico y político que descubre las ideas del Cristianisimo Luis XIV, para librar a la España de los infortunios que experimenta por medio de su legítimo Rey D. Carlos III. Viena, 1703, Gottfried WILHELM LEIBNIZ, Manifiesto en defensa de los derechos de Carlos III, rey de España, y de los justos motivos de su expedición, compuesta en 1703 y que consulto por la edición de Jaime de Salas de los Escritos de filosofia juridica y política de Leibniz (Madrid, Biblioteca Nueva, 2001, págs. 291/323), y François PAUL DE LISOLA, Défense del droit de la Maison d'Autriche. Colonia, Pierre Marteau, 1703, piezas monográficas compuestas todas en la estela de la proclamación del Archiduque como Carlos III en Viena a comienzos del otono de 1703 y cuyo contrapunto pasa por textos como el Crisol de la española fidelidad de Tomás de PugA Y Rojas (Granada, 1707) o el Phelipe V de José ARAnaz (El Señor Phelipe V es el Rey de las Españas verdadero, dado por la mano de Dios. Torre incontestable del segundo David perseguido y victorioso, guarnecida de tres propugnáculos, Justicia, religión y Politica, de que penden mil escudos que defienden su Corona. Pamplona, Francisco Antonio de Neyra, 1711) que funden el debate de los derechos dinásticos con la consideración confesional de la guerra.

${ }^{4}$ Cfr., los textos reunidos por PEREZ PICAZO, M. ${ }^{a} \mathrm{~T}$., La publicística española en la guerra de sucesión, II, Madrid, 1966, que ilustran bien las líneas y variantes dominantes del debate en el momento de composición de las Memorias. Para una reciente e informada puesta a punto de toda esa literatura, cfr., VICENT, I., "La cultura política castellana durante la guerra de sucesión", en Fernandez Albaladejo, P. (edi.), Los Borbones. Dinastía y memoria de nación en la España del siglo xvII. Madrid, Marcial Pons, 2001, págs. 217/243, y GonzÁlez Cruz, D., Guerra de religión entre príncipes católicos: el discurso del cambio dinástico en España y América (1700-1714). Madrid, Ministerio de Defensa, 2002.

Cir., al margen de piezas mayores como las ya citadas de Puga y Rojas y Aranaz, o la de Ignacio VICENTE SAVAlLos (Triunfos de la luz contra las oscuras tinieblas de la herejia y negras sombreas de la infidelidad. Córdoba, Acisalo Cortés de Ribera, 1707) la categórica Demostración política y legal para desengaño de la plebe cie Antonio IBÁNEZ DE LA RIVA compuesta en la primavera de 1706 (Archivio Sezreto Vaticano (ASV), Segreteria di Stato (Stato), Spagna (S), vol. 196), en la que se retoma el planteamiento ya expuesto por el propio Arzobispo de Zaragoza al Marqués de Mejorada el 21 de mayo de 1706 (Biblioteca Nacional (BN), Manuscritos, 5805), y cuya letra remite al discurso animado por el propio Felipe V desde 1704 (cfr., Pregón del Capitán General de 
diera decirse de la omisión de cualquier mención y consideración sobre las nobles miras patrióticas de los pretendientes que tanto predican y pregonan ambos referentes dinásticos. La ausencia de toda duda en la búsqueda de una precisa funcionalidad para su propia obra conduce al Conde de Robres por una vía nada frecuentada en su época. En el mejor sentido del término, la opción misma de unas Memorias al servicio de una historia liberaba al autor de las servidumbres y limitaciones más llamativas del novedoso entorno derivado de la duplicación de instancias dinásticas pretendidamente soberanas en el que las facciones sólo siembran historia o derecho para recoger legitimidad política entre la cosecha. Lejos entonces de procurar al texto una función política en su contexto, la verdadera muesca diferencial de la pieza de Robres venía dada por su decida vocación cívica de modular la prospección del drama de la guerra civil bajo forma de legado cultural y sedimento político que habilitase el cauce de acomodación en el imaginario hispano de un episodio que así, sin medias tintas, limpiamente se interioriza y entiende en sus páginas como antinatura ${ }^{6}$.

Al otorgar con tan genuino talante la estabilidad de la escritura a su visión de "la implacable guerra civil que padecemos», el Conde de Robres no sólo se ubicaba en las antípodas de unos artisans of glory cuyo papel en la narrativa histórica pasa por la exaltación de la monarquía. Operando con las facciones y no con la gloria como materia prima, ni su utillaje conceptual ni su comprensión de la materia guardan el más mínimo parentesco cultural ni la más mínima filiación intelectual con el léxico y la trama argumental que en aquel mismo 1708 emplea Antonio Cabrera de Córdoba al componer unas Glorias del Señor Felipe $V$, Rey de las Españas y Emperador del Nuevo Mundo. Tampoco hay rastro ni huella en las páginas de las Memorias del inquebrantable compromiso del príncipe nuevo con la

\footnotetext{
Aragón, de parte del Rey D. Felipe V, declarando la guerra al Archiduque Carlos III y al Rey de Portugal (1704), BC, Fullets Borisonms (F.Bon.), 522).

6 Cfr., como referencia, Pocock, J.G.A., "Thomas May and the narrative of Civil War", en HIRST, D. y STRIER, R. (edts.), Writing and political engagement in Seventeenth-Century England. Cambridge UP, 1999, págs. 112/144, del mismo, "The problems of history in the Hanoverian Kingdoms", en su Barbarism and religion. II. Narratives of civil government. Cambridge UP, 1999, págs. 163 y ss., y SMITTEN, J., "Robertson's ietters and the life of writing", en BRown, S. (edt.), WiIliam Robertson and the expansión of Empire. Cambridge UP, 1997, págs. 36/54. Idéntica interiorización de la guerra civil concurre también en otros autores del momento, aunque el discurso que se arma sobre esa percepción sea bien divergente al del Conde de Robres: cfr., Juan de la CRUZ, Compendio anua! de los sucesos principales de la Europa desde la muerte de Carlos II hasta el fin de 1705. Madrid, Imprenta Real, 1706, V, págs. 193 y 345/6, y Vicente de BacallaR Y SanNa, Monarquia Hebrea. Genova, Mateo Garbizza, $1719,11 / 4 .^{\circ}$, pág. 67: "La guerra civil es un interés, no público, sino particular de cada individuo, por esc es tan feroz".
} 
vigorosa epopeya de "restablecer la nación a su primitivo esplendor" que pregonan los autores con los que entonces una política de la historia adquiere su precisa forma y su auténtico sentido. No es desde luego el Conde de Robres ningún apóstol comprometido con la predicación del mensaje político más interesado en la figuración del soberano como "restaurador de la gloria de la nación" que tan bien ilustran, con su tramoya profética y cabalística, unos Ensayos de vaticinios reales de las dos Coronas bajo los que se desliza con fuerza el descarnado repudio político y constitucional de una Casa de Austria a la que se imputa, en la escena de la guerra civil, un efecto perverso y devastador sobre una España reducida, en palabras de Jacinto de Aranaz, a "mero cadáver de su antigua gloria»?

Pero el empeño de unas Memorias, preservar resueltamente como tributo a la memoria histórica una lectura de la guerra civil apegada y amparada por la tópica del lenguaje constitucional aragonés, también significaba romper amarras con el inequívoco espíritu y aroma político que envuelve alguna de las intervenciones historiográficas contemporáneas gestadas en latitudes forales. Al menos, el temprano fruto político que José Manuel Miñana procura madurar al imprimir con su De bello rustico valentino unos férreos tintes estamentales a la severa polarización de la fidelidad en un específico ámbito territorial hispano constituía una operación básica de política histórica sustancialmente divergente de la ensayada en el cuerpo de las Memorias ${ }^{8}$. La profunda convicción con la que el Conde de Robres afronta la escritura, la certeza que tras la cimentación del Continente de España sobre una nueva planta se cerraba todo un ciclo político e historiográfico de resultados ya inoperantes para la preservación de unos derechos con capacidad para configurar constitucionalmente a los reinos hispanos en términos territoriales, sellaba la decisiva bifurcación en cuya encrucijada las Memorias renuncian a colocar la historia al servicio político del presente.

Cfr., José Antonio IBÁNez de LA Rentería, Ensayos de vaticinios reales de las dos Coronas. París, Simón Langlois, 1712, págs. 12/13, 113 y 159, y Aranaz, Phelipe $V$, Dedicatoria y págs. 38 , 147 y $535 / 37$.

8 StIFFoni, Verita della storia, págs. 87/110; MEStRe. Sanchis, A., Historia, fueros y actitudes políticas. Mayans y la historiografia del XVIII. Universidad de Valencia, 2000, págs. 51/58, y del mismo. Don Gregorio Mayans y Siscar. Entre la erudición y la política. Valencia, Institució Alfons el Magnànim, 1999, págs. 233/34. Como reverso del discurso de Miñana, cfr., Juan de la Cruz, Compendio, V, págs. 194/95: :A los principios se vieron grandes demostraciones de fidelidad y amor a la patria en los valencianos, y se creyó que sólo vagabundos y hombres que no tenían que perder se interesaban en la mudanza; poco después se vieron los nobles tímidos o poco fervorosos en la conservación de su punio y amado Pais, entregándole sin que les obligase el poder ni la fuerza de las armas". 
Lejos de rebajar asi el perfil político del texto, con tan concienzuda llamada en causa de los diques de contención de la historia el Conde de Robres ante todo procuraba conjurar alguna de las principales implicaciones más propiamente políticas que pudieran derivar del naufragio de toda una cultura política y constitucional en las agitadas corrientes de la guerra civil ${ }^{9}$. La opción era sin duda la más consecuente y coherente con la propia concepción del itinerario y la secuencia del certamen civil que destilan las $\mathrm{Me}$ morias, la derivación lógica, si se quiere, de una lectura que detecta en una previa "guerra civil de plumas" la semilla de la que brota e imprime su verdadera magnitud y envergadura a una "guerra civil de las armas" ${ }^{10}$. Tan trasparente y plena confesión de la materia política que entiende se ventila y dilucida en la guerra civil es la que alimenta en el Conde de Robres la firme voluntad de enhebrar con el hilo histórico toda una serie de consideraciones genuinas de la semántica política del constitucionalismo aragonés sobre la contienda civil. La visión lúcida y fatalista del certamen civil como frontera política y constitucional fluía con naturalidad en las páginas de unas Memorias que en ningún momento pierden de vista que el triunfo de unas armas en el campo de batalla es el triunfo de unas letras en el gobierno de la monarquia y el descalabro de otras bien distintas. Ese era

9 Frente a los presupuestos de continuidad ininterrumpida entre pasado y presente que venían guiando una historiografía interesada por los orígenes de una comunidad política en cuanto espejo de unos valores culturales propios, -y cfr., Bızzocchl, R., Genealogia incredibili. Scritti di storia nell'Europa moderna. Bolonia, II Mulino, 1995, págs. 213/218, y WIEDENHOFER, S., "Erin nerte. Tradition und tradierte Erinnerung in Humanismus uns Reformation", en A. Assman y D. hartf (edts.), Mnemosyne. Formen und Funktionen der kulturellen Erinnerung. Frankfurt a.M., 1993, págs. 308/311 - la escritura de las Memorias del Conde de Robres arraigaba precisamente sobre la conciencia de quiebra de una tradición cultural y política que imprime a la historia una mixtura entre "public memory and private sentiment" (por utilizar el título de la contribución de SALBER PHILLIPS, M., "William Goodwin and the Idea of Historical Conmmemoratión: History as Public Memory and Private Sentiment» en CASTIGLIONE, D. y SAHRPE, L. (edts.), Shifting the Boundaries. Transformations of the Languages of Public and private in Eighteenth Century. Exeter UP, 1995, pags. 196:219).

10 Conde de RoBres, Guerras civiles, págs. 180 y 215, en los que se traza un estrecho vinculo entre la literatura política y la gestación y sustanciación de la guerra civil que ya habia recibido oportuna atención también en el contexto de 1640: cfr., A. SimON I TARRES, Els orígens ideologics de la revolució catalana de 1640. Barcelona, Publicacions de l'Abadia de Montserrat, 1999, y como muestra, la Memoria de la piedra de toque compuesta en 1641 (BC.F.Bon. 2.181, fol. 1 Ar), donde se lee que «para enturbiar a los que gobiernan, para hacer vacilar a los bienintencionados, para engañar al pueblo, y últimamente para sembrar cizaña, perturbar los ánimos, dividir las voluntades, despertar discordias y destruir a Cataluña con guerras civiles, van distribuyendo unos papeles sueltos que sumariamerite ofrecen perdón general a todos los catalanes, como si hubiesen delinquido en lisar del derecho de la natural defensa", o la dedicatoria de Alejandro Ros a Felipe IV de su Cataluña desengañada (Nápoles, 1646): «En un siglo tan cauteloso en el que se pelea más con libros que con ejércitos he querido militar en las armas de la pluma para ver si se gana Cataluña por el mismo camino por donde se perdió". 
entonces el verdadero desafío que se asume con la escritura: al margen de una declaración formal de insolvencia metodológica, la expresa renuncia a situar su composición dentro del campo de la historia no impide invocar y convocar la propia historia como depósito y refugio que pudiera garantizar la trasmisión de toda una concepción y comprensión de la política que así, con evidente desencanto, ya se entiende en trance de liquidación.

Unas Memorias, que ni se escriben en primera persona ni se conciben desde el ámbito y la torre de marfil de la privacy, encerraban y encauzaban de este modo para la historia una memoria que nada tiene de personal y autobiográfica porque efectivamente asume todas las apariencias de una más decisiva memoria de nación ${ }^{11}$. Al margen del escrupuloso respeto de los cánones clásicos de la tradición humanista, tan cuidadosa a la hora de escoger distintos términos para distintos ejercicios historiográficos como reacia a la escritura contemporánea de la materia histórica ${ }^{12}$, y confesando una confianza plena en el carácter retrospectivo de toda acti-

11 Cfr., como referencia fundamental para los registros propios y definitorios del cultivo y maduración histórica de una identidad nacional, GREENFELD, L., Nationalism: Five roads to modernity. Harvard U.P., 1992, con el oportuno complemento de SMITH, A., National ldentity. Londres, Penguin, 1991, que constata el canon cultural que imprime su significado y rige el entendimiento de la natio en ese momento y que tan bien ilustra e ilumina los cauces de superposición e implementación natural y pacífica entre esas identidades de signo nacional. Por lo que aqui además interesa su materia, son cuestiones todas a las que se puede seguir la pista mediante el ejemplar estudio de SAHI.NS, P., Fronteres i identitats: la formació d'Espanya i Françaala Cerdanya, s. xvII$x i x$. Vic, Eumo, 1993, y dos estudios indispensables para situar en sus justos términos la forja de esa memoria de nación en un horizonte hispano en ei que el monarca representa agregadamente a unos territorios: FeRnandez AlBaladeJo, P., "El problema de la composite monarchy en España", en Burdiel, I. y CASEY, J. (edts.), Identities: Nations, provinces and regions, 1550-1900. Norwich, School of History/University of East Anglia, 1999, págs. 185/201 y CLAVERO, B., «Anatomía de España: derechos hispanos y derecho español entre fueros y códigos », en Clavero, B., Grossi, P. y TOMÁs Y VALIENTE, F. (edts.), Hispania. Entre derechos propios y derechos riacionales. Milán, Giufré, 1990 , págs. 47/86. Por último, para la posibilidad de reconocer con mayor detalle las implicaciones e impulsos que subyacen en la asunción de la historia en contextos de cerrado conflicto civil como mirada a un tiempo pretérito mediante la que se procura sondear no sólo las claves de interpretación de esas contiendas contemporáneas sino proceder también a la definición de una identidad, cfr., MuLIER, E.O.G., "Between Humanism and Enlightenment: The Dutch Writing of History", en JACOB, M.C. y MIJNHARDT, W.W. (edts.). The Dutch Republic in the Eighteenth Century: Decline, Enlightenment and Revolution. Ithaca, Cornell UP, 1992, págs. 170/186.

12 Cir., GILBERT, F., Machiavelli and Guicciardini. Politics and history in sixteenth-century Florence. Princeton UP, 1973, págs. 206 y ss., Dusboss, C.G., La conception de i histoire en France au xvie siècle. París, A.G. Nizel, 1977, págs. 159 y ss., y Lozano, J., El discurso histórico. Madrid, Alianza, 1986 , págs. 40 y ss. Y cfr., también la elocuente precisión de Vicente Bacallar y Sanna al rendir cuenta del motivo por el que su obra sa presenta bajo titulación de Comentarios: «Lo malo que no publicó su propio autor lo callo, y callo mucho, por eso escribo Comentarios y no Historia, cuyas leyes para lo exacto de las noticias son más rigurosas". Vicente de BACALLAR Y SANNA, Comentarios de la Guerra de Esparia e historia de su Rey Felipe $V$, el animoso (que manejo por la edición de C. Seco Serrano, Madrid, Biblioteca de Autores Españoles, 1957), Dedicatoria. 
tud histórica, las Memorias del Conde de Robres procuraban dibujar unas vastísimas coordenadas de entendimiento histórico del trágico episodio, la guerra civil, en el que se erosiona y quiebra la identidad de unos territorios que es, en cierto modo, indisociable de la propia del autor ${ }^{13}$. La configuración narrativa no se aplica entonces únicamente a la historia rerum gestarum sino que forma parte de las propias res gestae. Antes que la propia guerra civil al Conde de Robres le interesa y le motiva en la escritura una identidad colectiva, el "antiquísimo ser" que luego diría Juan Amor de Soria ${ }^{14}$, cuyo proceso de liquidación es el que entiende que debe narrarse y legarse a la posteridad. Las Memorias, a las que nadie pide además citas de autores clásicos ni discursos intercalados, venian así a colorear la urdimbre de la guerra civil hispana con las tonalidades típicas de un combate entre identidades nacionales porque ese era el verdadero registro que procuraba inocularse en el seno de una futura historia del drama civil. La propia arquitectura argumental de las Memorias no podía ser más diáfana al respecto: en un verdadero alarde de circularidad, las letras iniciales y finales del texto confluían en la minuciosa disección y pormenorizada consideración dinástica, pero también nacional de la nueva planta que arrasa en el verano de 1707 los ordenamientos jurídicos propios de algunos territorios de la corona de Aragón. No es casual entonces, pero si sumamente sintomático, que unas Memorias ni tan siquiera sintieran la necesidad de asumir, como presupuesto e imperativo de rigor historiográfico previo a la escritura, los términos mismos de cancelación de la guerra civil. Tras la nueva planta, y al menos para el Conde de Robres, una recapitulación ya se imponía ${ }^{15}$. Pero la posibilidad de promover desde

13 Nada tiene que ver por tanto su interés por la tistoria con el gesto impostado y la dedicación descomprometida que domina tradicionalmente el apego de la nobleza hispana por la materia histórica. Cfr., Bouza, F., Corre manuscrito. Una historia cultural del siglo de oro. Madrid, Marcial Pons, 2001, págs. 248 y ss., y EGIDO. A., Humanidades y dignidad del hombre en Baltasar Gracián. Salamanca, Universidad de Salamanca, 2001.

14 Cfr., Juan de AMOR DE SOAIA, Para el examen de las cosas de Estado y las Reservadas, Real Academia de la Historia, 9-5637/10, cuya consideración de una Corona de Aragón que "perdió en la guerra civil su libertad, sus privilegios y su antiquísimo ser» trenza un enlace entre la materia jurídica y la identidad territorial cuya primera formulación corresponde al Conde de Robres. Para el texto de Juan de Amor de Soria, cfr., Liuch, E., Las Españas vencidas del siglo xvili. Claroscuros de la llustración. Barcelona, Crítica/Grijalbo Mondadori, 1999, págs. 70 y ss., y para un análisis más detallado de su itinerario intelectual, cfr., del mismo autor, “El pensament austracista i purificat de Juan de Amor de Soria", en L'alternativa catalana (1700-1714-1740). Ramon de Vilana Perlas i Juan de Amor de Soria: teoria i acció austracistes. Vic, Eumo, 2000, págs. 87/102, y Aragonesismo austracista (1734/1740) del Conde Juan Amor de Soria. Zaragoza, Institución Feinando el Católico, 2000.

is Y cir., MORENO NIEVES, J.A., "Los municipios aragoneses tras la nueva planta: la nueva administración y su personal político", Revista de Historia Moderna, 13/14 (1995), págs. 165/184. 
la narrativa histórica una revisión de los supuestos de fondo de la política de nueva planta, al modo del De bello rustico, abiertamente se abandona. La selectiva lectura y representación del itinerario de la guerra civil en la que se embarcaba el Conde de Robres no sólo procuraba un contexto para la ajustada comprensión del alcance político y la envergadura constitucional que supone la cancelación de una planta antigua sino que también, y quizás con mayor énfasis, procuraba acomodar el episodio, así entendido, en la esfera de comunicación entre la memoria individual y la colectiva, en la precisa intersección por tanto en la que una memoria devenía en instrumento constitutivo de la identidad ${ }^{16}$.

Alejadas del cultivo de las antigüedades tan común entre los grupos eruditos aragoneses del Seiscientos ${ }^{17}$, y liberadas de los condicionantes propios de la intervención historiográfica en el magno debate de la prelación de los derechos dinásticos, las Memorias no sólo renuevan la indumentaria que tradicionalmente venía arropando la concepción de la historia como magistra vitae, su conversión en oráculo de prudencia en el seno de la filosofía moral y así su figuración como manantial que suministra un caudal indispensable a la prudencia del príncipe ${ }^{18}$. También quiebran, de manera paralela, la confesional reclusión de la memoria en las férreas fronteras de la oratoria sagrada ${ }^{19}$. $Y$ así, firmadas por alguien que ni era ni

16 Crr., Burke, P., "History as Social memory", en Butler, Th. (edt.), Memory. History, Culture and Mind. Oxford U.P., 1989, págs. 97/113; NorA, P., "Entre mémoire et histoire", Les lieux de mémoire, I, La République. París, Gallimard, 1984, págs. XVI1/XLli; SAHLINS, F.L., Islands of History. Chicago UP, 1992, y HUTTON, P., History as an Art of Memory. Hannover, University of Vermont, 1993.

17 Cfr., Egloo, A., La rosa del silencio. Estudios sobre Gracián. Madrid, Alianza, 1996, cap. VII, y de la misma, "La Nobleza virtuosa de Doña Luisa de Padilla, condesa de Aranda", en Archivo de Filologia Aragonesa, LIV-LV (1998), pp.9/41. Y como ilustración, SELIG, K.L., The library of Vincencio de Lastanosa. Ginebra, Droz, 1960.

$18 \mathrm{Cfr}$., las interesantes consideraciones sobre ia materia de VALERA, G., "Storia filosofica e filosofia della storia nell elaborazione teorica dell aufklärung", en GENuA, M. y PESANTE, M.L. (edts.), Passioni, interessi, convenzioni. Discusión settecentesche su virtù e civiltà. Milán, Franco Angeli, 1992, págs. 311 y ss; y Koselleck, R., Fufuro pasado. Para una semántica de los tiempos pasados. Barcelona, Piados, 1993, págs. 41/66. Para los términos confesionales hispanos en los que tradicionalmente se venía vinculando la historia y la prudencia, con la experiencia como eslabón de engarce, cfr. INUURRITEgUI, J.M., "Lo pasado y lo presente", en MARTínez Shaw, C. (coord.), Arte y Saber. La cultura en tiempos de Felipe II y Felipe IV. Madrid, MEC, 1999, págs. 131/140, y EGIDO, A., Las caras de la prudencia y Baltasar Gracián. Madrid, Castalia, 2000.

19 Pese a la combinación de motivos cristianos y paganos que permite a Valentina Nider plantear "la disimulación como prudencia divinamente política" - y tomo parcialmente el título de su colaboración en ÉTIENVRE, J.P. (edt.), Littérature et politique en Espagne aux siecles d'or. París, Klincksieck, 1998, págs. 423/434- para la operación de sacralización de un instrumento retórico como la memoria en el horizonte de la cultura barroca hispana cfr., RODRIGUEZ DE LA FLOR, F., Teatro de la memoria. Siete ensayos sobre mnemotecnia española de los siglos xvil y xvil. Salamanca, Junta de Castilla y León, 1988 
pretendia ser historiador, asumen con tanta naturalidad como deliberación una fisonomía manuscrita ${ }^{20}$. Dispuestas en estampas anuales que conducen al lector desde el laberinto sucesorio hasta el invierno de 1708 , en la renuncia a la tipografía evidentemente podía pesar una posibilidad de prolongar la escritura que se intuye en sus páginas finales, boceto y esbozo del arranque de 1709. Pero en la opción manuscrita lo que sin duda parecía primar era la voluntad expresa del autor, que así retrataba con plena nitidez el espíritu de su obra: “desearía poder trasmitir a mis sucesores y al público una historia de nuestra infeliz era que, reservada en lo muy secreto de una gabeta, pudiese en tiempos menos peligrosos aprovecharles» ${ }^{21}$. En una especie de pedagogía cívica y constitucional, la elevada mira del Conde de Robres pretendía grabar en lo más hondo de la memoria comunitaria la tragedia mayúscula que significa y supone la guerra civil: "es de temer que, faltando a la posteridad una relación verdadera de las causas y progresos de tan gran mal, falte también la instrucción conveniente para evitarle en adelante". Tan alta esperanza, la institución cívica en el origen y las causas de una situación contra natura como el combate doméstico en el que se quiebran y disuelven los lazos y los vínculos civiles, definía luego su específica tonalidad política con la semántica constitucional aragonesa que conceptualmente la encauza como memoria de nación ${ }^{22}$. En la gabeta encon-

20 Y cfr., BouzA, Corre manuscrito, págs. 241 y ss.

21 CONDE DE ROBRES, Guerras civiles, Proemio. Esa polivalente concepción temporal que domina la escritura del Conde de Robres, el manejo y percepción del tiempo presente que es el sujeto de la narración como tiempo ya pretérito para unos descendientes que se asumen por destinatarios de la obra, encierra el verdadero talante cívico y político de la escritura de éste género de memorias y diarios: cfr., las consideraciones y oportunas acotaciones que al respecto realizan AmELANG, Flight of Icarus, passim, SIMON I TARRES, A., "Memorias y diarios personales de la Cataluña moderna", Historia Social, 2 (1988), págs. 119/134; EsCARTi, V.J., Memòria privada.Literatura memorialistica valenciana del segle XV al XVIII. Valencia, E. Climent, 1998, y TORRES, X., Els IIibres de familia de pagés. Memòries de pagés, memóries de mas [seges XVI-XVIII. Girona, CCG Edicions, 2000. Ahora además, y sin abandonar el contexto de la guerra de sucesión, es posible constatar las variantes que admite el género, y asi situar mejor las Memorias del Conde de Robres, mediante la consulta del Dietari del Convent de Santa Catarina y las Memmóires d'Honorat de Pallejà que edita J. ALBAREDA bajo titulo conjunto de Política, religió $i$ vida quotidiana en temps de guerra (1705-1714). Vic, Eumo, 2001.

22 Sobre el papel que tradicionalmente venía desempeñando en latitudes aragonesas la figura del cronista en la modelación de un "método de representación del reino" y así de una memoria territorial sobre la base de una cultura foral, de una comunidad de conceptos e ideas que tópicamente se consolidan en el entorno del fuero, cfr., NAVARRO BoniliA, D., "Cronistas aragoneses y' escrituras: el método de la representación del reino", Emblemata, 5 (1999), págs. 107/142; CONDE DE LA VINAZA, Los Cronistas de Aragón, que manejo por la edición de M. ${ }^{a}$ Carmen Orcastegui y Guillermo Redondo (Zaragoza, Cortes de Aragón, 1986), y CABANES PECOURT, M.D., «Los cronistas de Aragón", Quinta muestra de documentación histórica de Aragón. Cronistas de Aragón. 
traba así acomodo el relato histórico pero también las credenciales de una cultura política y un género de identidad en las que el autor busca y encuentra la indispensable asistencia para procesar la propia experiencia y la propia subjetividad inherente a quien por embarcase en la escritura de la ratio de una guerra civil no puede despojarse de su papel ni omitir su condición como activo participante en la misma. Tan decisiva incidencia de la savia política en el tronco de la precoz narrativa de la guerra civil en realidad no dejaba de insinuarse con delicadeza en la breve presentación de la obra. Jugar la baza manuscrita de unas memorias, en confesión del autor, podía resultar también el cauce más adecuado para evitar la poderosa interferencia que en el contexto del certamen civil ejercían las pasiones sobre el ámbito de la política y la cultura, historia así incluida.

Sin necesidad de emprender un despliegue mayor, ni aportar una argumentación más elaborada, el Conde de Robres perfila en ese orden de cosas una diáfana identificación y velada descalificación de la servidumbre política que las pasiones imponen a una historiografía, anticipando ya directamente un motivo y materia capital que pronto había de suscitar intentos de consideración más cumplida o construcción más autónoma. Cifrada a modo de aforismo, la tesis de fondo de unas sugerentes Reflexiones sobre la historia, que encuentran cabida y acomodo en el cuerpo del enciclopédico Teatro Crítico Universal de Benito Feijoo, apuntaba sin rodeos, algunos años después, en idéntica dirección: "la verdad navega en el mar de la historia siempre entre dos escollos: la ignorancia y la pasión". Interesado en desvelar las alargadas sombras proyectadas por las pasiones con las que toda historia y todo historiador habían necesariamente de hacer sus cuentas, Feijoo descubria dos géneros historiográficos singularmente vulnerables frente a los corrosivos efectos del intenso influjo pasional: las piezas en las que el historiador asumía su propio tiempo histórico o su propia nación. Si el cultivo de la historia, por definición en el

Zaragoza, Centro de Documentación Bibliográfica Aragonesa, 1992, págs. 13 y ss. Para la dedicación a la historia de las academias de Zaragoza y Huesca, como exponente de una vida cultural aragonesa impregnada del gusto por el saber histórico desde el Quinientos, cfr., EgIDO, A., "Las Academias literarias de Zaragoza en el siglo XVII". La literatura en Aragón, Zaragoza, Caja de Ahorros de Zaragoza, 1984, págs. 101/128. Y para la distinción entre "national epos" e uinstitutional past", entre una épica nacional labrada por los cultores de la memoria patria y un pasado institucional apegado al léxico de las instituciones políticas más frío y aséptico pero no menos eficaz que la narrativa que encauza la invención de la tradición, cfr., Pocock, J.G.A., «England», en Ranum, O. (edt.), National Conciousness. History and Political culture in Early Modern-Europe. Baltimore, John Hopkins U.P., 1975, págs. 1/19. 
predicado del benedictino, no admitía aficionados, las exigencias habian de extremarse en esas precisas modalidades temáticas. La escritura y la lectura, en toda materia histórica, comparecian en las Reflexiones como caras de una misma moneda, dimensiones tan vinculadas como propias de la física pasional: «la misma pasión que a los historiadores induce a escribir es regla que determina a los lectores a creer". Ahora bien, sólo en los sinuosos meandros de la historia nacional aquel magma desvelaba su verdadera inestabilidad: "No sólo un enemigo milita contra la verdad en los escritos nacionales. Quiero decir, que no sólo el amor sino también el temor los hace apartar del camino derecho. Cuando no los ciega la pasión propia, tropieza con la ajena” ${ }^{23}$. Inmerso en uno de los más supremos teatros pasionales, el de la guerra entre socii, entre aliados que comparten cabecera monárquica, y con unos sujetos precisamente nacionales como actores principales de su versión e interpretación de la guerra civil, ni la opción manuscrita del Conde de Robres, ni su renuncia a la historia a favor de una memorias, resultaban por tanto excéntricas e inoportunas. Al fin y al cabo, todo lo que la prosa rica y precisa de Feijoo captura con soltura lo podía descubrir el Conde de Robres con una simple mirada por un panorama que no duda en calificar como desolador: "es peligroso desplegar al público con la pluma la verdad, porque se ha hecho ya carácter de entrambos partidos el esforzar la mentira; y fuera de eso, dominando enteramente a la razón la voluntad, nos vemos miserablemente reducidos en un caos por todas partes inaccesible" ${ }^{24}$.

La cuestión, la interferencia de las pasiones en la historiografía, era un campo hasta cierto punto ya trillado por la literatura política previa a la guerra civil. Embarcado en la remodelación de la tradicional pedagogía

23 Benito Jerónimo FEIJOO, "Reflexiones sobre la historia", en su Teatro Crítico Universal, IV, Madrid Viuda de Francisco del Hierro, 1730 (que cito por la edición de la Biblioteca de Autores Españoles, Obras escogidas del Padre Feijoo, Madrid, Atlas, 1952, págs. 160/180. Para la llamada en causa de las pasiones y su irrupción en la concepción de la historia, cfr., TARANTO, D., Pirronismo ed assolutismo nella Francia del'600. Milán, Franco Angeli, 1994, págs. 107 y Ss.; BORGHERo, C., La certeza e la storia. Cartesianismo, pirronismo e conoscenza storica. Mián, Franco Angeli, 1983, passim, y Bertell, S., Rebeldes, libertinos y ortodoxos en el barroco. Barcelona, Pe nínsula, 1984, págs. 197 y ss., y 223 y ss.

24 Conde de Robres, Guerras civiles, Proemio. Una percepción, por lo demás, común en el momento de composición de las Memorias, como lo certifican las palabras de José de Yerno en su aprobación al tomo quinto del Compendio de Juan de la Cruz: «Sabemos cuanta es la confusión en toda Europa, pues no hay acontecimiento que no lo cuente con diversos colores cada una de las Cortes y aún cada uno de los cortesanos que las componen", o las del Marqués de San Felipe en la dedicatoria al monarca de sus Comentarios: "En guerra de intereses tan varios y complicados de acciones por política o pasión, con tanta diversidad referidas, mucho ignoraré». 
política hispana, en las páginas del hombre práctico de Francisco Gutiérrez de los Ríos y Córdoba las prevenciones no podían ser más elocuentes: "en las historias encontramos el mismo vicio de pasión en sus autores, variando los discursos y los hechos cada uno a favor de su pueblo o del partido que siguió en él» ${ }^{25}$. También por entonces, y al presentar en sociedad su Corona Real del Pirineo, Domingo de La Ripa ubicaba con decisión en las pasiones la semilla de la que brotan las intervenciones de Abarca, Moret o Pellicer en el seno de aquella magna disputa historiográfica incardinada sobre los Fueros de Sobrarbe ${ }^{26}$. Incluso una cierta jerarquía, coronada por la pasión patriótica, ya parecía venir insinuándose, desde el momento que en una fecha tan significativa como 1700 , y al presentar la primera entrega de su Sinopsis, Juan de Ferreras siente la necesidad de recitar que «las leyes de la historia son referir sin pasión lo próspero y lo adverso, sin dejarse cegar del amor a la patria". Toda esa incipiente disposición de una narrativa histórica para eliminar de su horizonte las pasiones se desvanecía con la convocatoria del certamen civil, como no duda en certificarlo el Conde de Robres que así, con evidente premeditación, opta por adentrarse en la senda manuscrita de unas memorias. Pero quizás lo sintomático es que aquella línea, pese a tentativas bien armadas ${ }^{27}$, tampoco se retomaba tras la cancelación del conflicto. Entonces una apasionada política de la historia se impone, lo impide, y no es sólo la gabeta del Conde de Robres la que así parecía perderse con más pena que gloria. En realidad toda la historiografía interesada por la traumática experiencia de la guerra civil del amanecer del Setecientos

25 Fernando GutiérRez de los Rios y CóRDOBA, El hombre práctico o discursos varios sobre su conocimiento y enseñanza. Bruselas, Felipe Foppen, 1686 (que cito por la edición de J. Pérez Magallón y R.P. Sebod, Córdoba, Cajasur, 2000), pág. 242. Para el texto, y una ajustada visión de su contexto, cfr., Pérez Magallón, J., Construjendo la modernidad. La cultura española en el tiempo de los novatores (1675/1725). Madrid, Consejo Superior de Investigaciones Científicas, 2002, págs. 263/290, y Carrasco Martinez, A., «Los Grandes, el poder y la cultura política de la nobleza en el reinado de Carlos II", Studia Historica. Historia Moderna, 20 (1999), págs. 77/136.

${ }_{26}$ Domingo LA RIPA, Corcna Real del Pirineo, establecida y disputada. Zaragoza, Herederos de Diego Dormer, 1685, "Al que leyere".

27 Como la de Jacinto Segura a la altura de 1733 en lo que se pensó como Preceptos de critica para estudiosos de la historia pero que en el laberinto de la licencia y la aprobación se bautizó como Norte Crítico (que cito por la edición de N. Bas Martín, Alicante, Instituto de Cultura Juan Gil Albert, 2001). En la división primera del discurso VIII, De la fe histórica a escritores coetáneos, y llegado el argumento al punto del "amor a la patria", las pasiones veladamente quedaban convocadas y los intereses invocados: "En las ristorias de la Patria, de sus Principes, de las Glorias de sus Naciones, de sus Gremios y de las guerras de sus provincias hay mucho que discernir en los historiadores, porque es muy ordinario que prevalezca con exceso la afección, y se empeñen en aumentar lo favorable de las victorias y conquistas, y en disminuir lo adverso, con notable disonancia y defecto de verdad" (Segura. Norte Crítico, pág. 436) 
hispano encuentra infranqueables obstáculos en el laberinto de la política cultural de su época ${ }^{28}$.

La materia ciertamente no queda sumida en la oscuridad ni los historiadores eliminan la cuestión de su horizonte. Pero la confrontación doméstica y el certamen dinástico europeo motivados por la sucesión de la corona católica tampoco logra durante décadas alcanzar un espacio historiográfico propio ni afirmar asi su sentido en la modelación y sedimentación de una memoria histórica hispana. Lo impide y condiciona la más pura política de la historia, con su objetivo de construir, con el pasado y en el presente, un modelo de futuro y un género de identidad nacional entonces en proceso, nada pacífico, de gestación y definición ${ }^{29}$. La incidencia de una operación de política histórica de ese signo sobre el cultivo de aquella historia que asume por objeto una contienda civil sin precedentes desde los tiempos de afirmación católica de la monarquía se hace ya evidente desde el mismo momento de comparecencia de las primeras tentativas de procesar bajo forma histórica el episodio de unas dichas guerras de España: los Comentarios de las Guerras de España del Marqués de San Felipe y la Historia civil de Nicolás Belando, los primeros frescos monumentales del certamen civil y el gobierno de Felipe $V$, naufragan de inmediato en los vericuetos de una arena política en la que así se descubren obstáculos infranqueables ${ }^{30}$. El inequívoco aroma político de esas censuras inquisitoriales, cuya esencia captura el turbulento proceso de ajuste del gobierno de la monarquía en la estela del conflicto civil, confluye además con la clausura de toda una veta historiográfica cuyo utillaje conceptual se entiende incompatible con la renovada comprensión de la política entonces en trance de afirmación. No es de extrañar por tanto que si por los imperativos de la política venía a cancelarse el empeño historiográfico

28 Y cfr., Stiffoni, Verita, págs. 111/158, MeStre Sanchis, A., "Historiografia», en Agultar Piñal, F. (edt.), Historia literaria de España en el siglo xvil. Madrid, Trotta/CSIC, 1996, págs. 815/882, Perez Magallón, Construyendo la modernidad, págs. 163 y ss., y Alcáraz Gomez, J.F., Jesuitas y reiormismo. Valencia, Facultad de Teología San Vicente Ferrer, 1995, págs. 511 y ss.

29 Fernández Albaladejo, P., "Dinastía y comunidad política: el momento de la patria», en Fernández Albaladejo, Borbones, págs. 485/532.

30 Para los detalles del proceso inquisitorial contra la Historia civil de España de Nicolás de Jesús Belando, cfr., ZavalA, I.M., Clandestinidad y libertinaje erudito en los albores del siglo xviI. Barcelona, Ariel, 1978, págs. 367/375; StIFFONI, G., «Due momenti della storiografia del primo settecento spagnolo: Miñana e Belando", Rassegna iberistica 22 (1985), págs. 3/27; AlCARAZ, Jesuitas, págs. 403 y ss., y sobre la suerte inicial de los Comentarios del Marqués de San Felipe, cfr., el estudio preliminai de C. Seco Serrano (esp. págs. LXXI/Il) en la edición ya citada, y BoGLIol.10, E., Tradizione e innovazione nel pensiero político di Vicenzo Bacallar. Milán, Franco Angeli, 1989, págs. 189 y ss. 
de unos artisans of glory todo un rico yacimiento textual, con su bien diversificada semántica de significados políticos, quedara profundamente sepultado.

El tortuoso destino manuscrito que comparten piezas tan dispares como las Memorias de Macanaz, las Memorias para la historia desde la muerte de Carlos II hasta el año de $1711^{31}$, o su reverso en materia de cultura política, las Memorias del Conde de Robres, las monumentales Narraciones de Castellvi y las Adiciones y notas históricas de Juan de Amor de Soria, retratan la genética política que rige la demarcación de una historiografía. Bajo el decidido repudio de unas visiones historiográficas genuinas no es difícil detectar que fluía la firme determinación de romper amarras con los lenguajes políticos que las modulan: el cauce por el que se deslizan el texto de Robres y las Narraciones de Castellví, la comprensión del continente de España como agregado de naciones ${ }^{32}$, o el es-

31 Fiel a su talante y trayectoria política, el propio Melchor de Macanaz años después también podía rendir cuenta y testimonio de las proporciones políticas antes que históricas que rigen el terreno más básico de la historiografía al justificar una enmienda a la totalidad del texto de Belando que aprovecha igualmente para ajustar cuentas pendientes con personajes como Alberoni, Daubenton o Ripperdá: "cierro este compendio con mis notas y adiciones a ella, porque la posteridad no quede defraudada de las verdades que Belando dejó de decir por miedo del gobierno tiránico que aún dura en esta nuestra España". Cfr., Melchor dE MACANAz, Los males, daños y perjuicios que ha ocasionado a la España, a su Iglesia y a su Rey los Extranjeros que han tenido manejo en el Ministerio español. Todo en las notas puestas a la Historia civil de España que compuso el $R$. $P$. Fr. Nicolás de Jesús Belando, del orden de NPS Francisco y comprende el reinado de don Felipe Quinto, manuscrito fechado el 20 de octubre de 1744 (BN, Mss., 2768).

32 Cfr., Francisco DE CASTELLvi, Narraciones Históricas (que cito por la edición de J.M. Mundet i Gifre y J.M. Alsina Roca, Madrid, Fundación Francisco Elías de Tejada y Erasmo Pèrcopo, 1997) I, págs. 54/56, donde se concentran las aclaraciones conceptuales preliminares - “Antes de escribir el resumen histórico y tabla cronológica desde el Príncipe don Pelayo hasta el rey Fernando el católico, ha parecido a personas eruditas ser precisas algunas suposiciones que sírvan de más luz para la inteligencia de lo que se referirá. He advertido con el trato de diferentes naciones que muchos que son considerados instruidos en ella reciben notorias equivocaciones respecto a la España; y no pocos creen que los reinos y provincias que contiene la España tienen un mismo idioma, las mismas leyes, exenciones, costumbres y los mismos trajes" - la premisa de trabajo sobre la que se elabora el texto - "De todo esto se ve claro que aunque en todo el continente de España se nombran sus naturales en común españoles, eran y son distintos y se conservaron mucho tiempo divididos"-- y el mensaje que más interés se tiene en transmitir: "eran estas naciones en el continente de la España distintas en leyes, costumbres, trajes e idiomas". Sobre ese preciso perfil de las Narraciones de Castellví, cfr., ARRIETA, J., "L'antítesi pactisme-absolutisme durant la guerrá de Successió a Catalunya", en AlbAREDA, J. (edt.), Del patriotisme al catalanisme. Vic, Eumo, 2001, págs. 102/103. Y como contrapunto, cfr., la primera entrega de la Historia civil de España de Nicolás Jesús de Beiando (Madrid, Manuel Fernández, 1740), cuya presentación ya asienta el protagonismo que se confiere a las "admirables acciones de V. Mag.", pero también el papel estelar que en la narración se reserva a "las admirables acciones de los españoles", anticipando asi los dos sujetos, el monarca y la nación española, sobre los que se procura y pretende tejer una historia que se predica civil y y que abiertamente se dice propia de España. 
tilo político de Amor de Soria, la interiorización de la guerra civil como significativa ocasión para reflexionar sobre el conflicto y composición entre auctoritas y libertas, apegados todos al léxico constitucional aragonés de patria y libertades, resultaban ser muescas de un preciso entendimiento de la política ya clásico en latítudes hispanas cuyo rastro precisamente se pierde tras el certamen sucesorio. Un cierto cultivo de esos lenguajes en verdad se mantiene. No faltan voces que predican, y más lejos no podía llegarse, la posibilidad y la urgente necesidad de proclamar una «Republica lliure del Principat de Catalunya" sobre la base de su «integritat antigua» ${ }^{33}$. Todo manantial historiográfico tenía desde luego su desembocadura política. Pero como en todo combate en la guerra civil sucesoria también la victoria de un bando implica la derrota del otro, y era bien difícil que la historia pudiera proporcionar la vía de reubicación en el tapete hispano a una semántica política que los implicados en la acuñación de una nueva erudición política y una nueva ciencia de estado no dejaban de concebir, imaginar y menospreciar como un fósil inservible y un fantasma maligno.

Entre la historia y la política, una política de la historia imponía su ley y la cultura hispana podía así atravesar el meridiano del Setecientos sin asentar como temática capital de una reflexión historiográfica de envergadura aquel episodio que sin duda deja una huella más honda en la fisonomía constitutiva y constitucional de la monarquía desde la época bajomedieval. El desembarco historiográfico que Robres pretendía para sus Memorias no encontraba desde luego el terreno abonado. En verdad, podian brotar ramas y esquejes de aquel tronco historiográfico debilitado por imperativos de naturaleza política nada sensibles y apegados al rigor histórico. Sin ir más lejos, Maudave, en su ferviente y laudatorio discours préliminaire a la edición francesa de los Comentarios del Marqués de San Felipe, bien que procura encumbrar la materia a los altares historiográficos y de paso apuntar la rémora que supone la censura de su versión original ${ }^{34}$.

33 Cfr., LLuCH, Españas vencidas, págs. 66 y ss., del mismo, «El judici imperial sobre la Via fora als adormits", Bulleti de la Societat Catalana d'Estudis Historics, X (1999), págs. 67/88; ALABRús, R.M., Felip V i la opinió dels catalans. Lleida, Pagès editors, 2001, págs. 392 y ss.; LEON SAN7, $V$., "La influencia hispana en el reformismo de la monarquía austriaca del Setecientos", Cuadernos Dieciochistas, 1 (2000), págs. 107/132, de la misma, "Cultura española y poder político en la Corte de Viena del emperador Carlos VI (1711/1740)", Reales Sitios, 152 (2002), págs. $30 / 47$, y los textos reunidos por J.M. TORFES I RIBE en el vol. Il de los Escrits politics del segle xvil. Vic, Eumo, 1996.

${ }_{34}$ Mémoires pour servir a /'Histoire d'Espagne sous le regne de Philippe $V$. Ámsterdam, Zacharia Chatelain, 1756, Discours préliminaire, págs. $V-$-Cet ouvrage roule sur une matiere connue, a la verité, mais qui ne peut cesser de nous paroître intéressante par le grandeur des objets, 
Incluso en aquel mismo 1756 en que comparecen en Amsterdam las Mémoires pour servir a l'historie d'Espagne sous le regne de Philippe $V$, José del Campo-Raso publica en Madrid unas Memorias politicas y militares para servir de continuación a los Comentarios del Marqués de San Felipe. Con todo y con eso, la tendencia sin embargo no se invierte. La condena, y las paradojas así se multiplican, ni tan siquiera impedía un uso político de textos como los Comentarios aunque mutilase una historiografía. Al menos en tiempos de Carlos III el anónimo autor del Genio de los Catalanes podía incorporar literalmente alguno de sus fragmentos en lo que constituye una tentativa de reanimación de la antigua tópica castellana más crítica en la interiorización de un lenguaje patriótico catalán que ahora, en clave de felicidad pública, insinuaba la necesidad de revisar los supuestos de fondo del diseño de la nueva planta ${ }^{35}$. Esa era en realidad la cuestión. Que llegado el atardecer del Setecientos Juan Francisco Masdeu incluso pudiera plantear en los albores del debate constituyente hispano la restauración de figuras como el Justicia de Aragón cuando todavía una historiografía no había procedido a la fijación del marco histórico y político en el que una operación de ese signo, la recalificación constitucional del Continente de España, tiene lugar ${ }^{36}$.

Ese nuevo orden jurídico y político que impone la nueva dinastía en el contexto de las guerras de España, la dicha nueva planta, era precisa y sintomáticamente el motivo que a la altura de 1752 induce a Gregorio Mayans a promover la edición de una de las primeras piezas manuscritas de aquella narrativa de la guerra civil reducida ya a cenizas: el De bello rustico valentino de José Manuel Miñana. El texto, cuya composición arranca en el verano de 1707 y se concibe como pieza política de combate, comparece entonces con una finalidad no menos política pero si diversa a la

par les evenemens variés \& inouïs, par l'epoque d’une révolution importante qui a changé la facede l'Europe, \& qui doit étre à jamais consacrée dans les fastes des deux plus puissantes Nations de cette partie du monde»-y XVII.

35 Cfr., Genio de los naturales de Cataluña (BC, Mss. 119). La pieza mayor del giro lingüístico y conceptual con el que desde el meridiano del siglo se procura la revisión de los supuestos de fondo de la nueva planta, el exponente primero y principal de un discurso renovado que combina la invocación de una felicidad pública y un relativo abandono del tradicional cauce de interposición frente a lá misma del lenguaje constitucional más interesado en la delimíación de la potestad normativa, el Memorial de greuges de 1760, puede ahora consultarse en la edición de J.M Torras i Ribe dentro ciel ya citado volumen II (Documents de la Catalunya sotomesa) de los Escrits politics del segle XVIII, págs. 91/113, y puede también ahora mejor contextualizarse merced a FERnÁndez Albaladejo, Diriastia, págs. 524/525, y Alabrís, Felip V págs. 417 y ss.

$36 \mathrm{Cfr}$, MANTELLI, R., The political, religious and historiographical ideas of Juan Francisco Masdeu, S.J., 1744-1817. New York/Londrés, Garland, 1987, págs. 73 y ss., esp. págs. 89/104. 
inicial del autor. Más que aportar un cuadro minucioso y pormenorizado del conflicto civil en latitudes valencianas, al editar el De bello rustico Mayans procuraba habilitar el cauce para una consideración más cumplida del proceso de liquidación del derecho propio y privativo de un reino. Su proyecto editorial convertía a un texto en contexto para la lectura de una intervención del monarca sobre la parte más estructural y constitutiva de la monarquía, la constelación de derechos territoriales, y asi en simiente para el cultivo de una memoria histórica atenta a las antiguas libertades. Esa era la intención: la llamada en causa del proceso que culmina en la ruina de unas antiguas libertades ${ }^{37}$. Nadie quizás como Mayans ilustra entonces con tanta claridad las implicaciones políticas que encerraba el silencio historiográfico sobre la guerra civil incubada en el ocaso del Seiscientos e inaugurada con el alba del Setecientos. El silencio absoluto que impone una censura política a unos pretendidos artisans of glory. Pero también el silencio con el que los mismos sepultan episodios como la nueva planta hasta recluirla en los arrabales de la cartografía historiográfica trazada en la estela de la contienda civil ${ }^{38}$.

El asunto, el barrido inicial de ciertos derechos con capacidad para configurar constitucionalmente a los reinos de la monarquía en términos territoriales, no puede decirse que vagara perdido entre las laudatorias recapitulaciones de las gestas del nuevo monarca y la nueva dinastia. La más reciente evolución política y jurídica de la monarquía, en cierto modo, tenía curso corriente en los afluentes que modulan aquella historiografía previa a la gestación ilustrada de una perspectiva civil de contemplación y comprensión histórica del ordenamiento hispano. La nueva planta, la disposición de unos derechos territoriales por parte de un monarca, al menos es motivo y materia que comparece desde el mismo momento en que una literatura jurídica se adentra en el laberinto de la exploración e identificación histórica de un derecho que pudiera predicarse y proclamarse patrio ${ }^{39}$. Es más, en ese preciso género cuyo marco conceptual y entramado

37 Cfr., Gregorio Mayans al Conde de Lynden, Oliva, 7 de septiembre de 1752, en José Manuel Miñana, Guerra de sucesión, pág. 306.

38 $Y$ cfr., como ejemplar del distanciamiento crítico de Mayans frente a esa cepa historiográfica, las duras palabras que dedica a los Comentarios de Bacallar y Sanna y que se recogen en Miestre SANChis, A., Correspondencia de los ilustrados andaluces. Sevilla, Quinto Centenario, 1990, pág. 154.

${ }_{39}$ Cfr., VAlLEJo, J., «De Sagrado Arcano a constitución esencial. La identificación histórica del derecho patrio", en Fernandez Albaladejo, Borbones, págs. 423/484, y Clavero, B., "Leyes de la China: origenes y ficciones de una historia del derecho español», Anuario de Historia del Derecho Español, LIl (1982), págs. 193/221. 
argumental rinde cuenta puntual de la perseverancia de una cultura en la percepción de la categoría foral como consustancial a la lógica de la monarquía católica, también buscan y encuentran su espacio lecturas de la nueva planta nada ingenuas desde el punto de vista politico en su tímida demarcación de ámbitos de convivencia entre unas leyes patrias y unas leyes municipales ${ }^{40}$. No obstante todos esos matices y esas pinceladas, por livianas que fuesen, se difuminan en los sondeos historiográficos de la guerra civil y el gobierno de Felipe V. Una sustantividad propia y verdadera como motivo fundamental de una reflexión historiográfica no se le reconoce. Desde la propia selección de materiales y problemas, todas las piezas tempranas que modulan la historiografía de la guerra civil parecian por el contrario eliminar de su horizonte cualquier consideración más cumplida y pormenorizada del momento constituyente del Continente de España sobre una nueva planta. Al menos, Vicente Bacallar y Sanna, en la urdimbre de sus Comentarios de las Guerras de España, podía levantar acta y liquidar la cuestión con un mero puñado de líneas, y Nicolás Belando, en su monumental Historia civil, dedicarle más espacio y atención a la letra de los decretos de 1707 que a su sentido y significación, buscando además el amparo del decreto de abril de 1711, que circunscribe la derogación foral al ámbito del gubernaculum, para predicar que unos fueros "más fueron moderados que abolidos» ${ }^{4}$.

Lejos además de responder a la mirada propia de un autor, a su opción así indisociable de una retícula de intenciones e intereses, lo significativo es que el perfil historiográfico bajo de la nueva planta impregnaba casi todos los rincones de la narrativa motivada por las guerras de España. Por muy copiosos que fueran sus ecos en el espacio de la literatura más sensible al valor epistemológico de la historia, lo relevante es que tam-

\footnotetext{
40 Cfr., por la posibilidad de trazar desde aqui una línea que luego se retoma y desarrolla con fuerza en el Memorial de greuges, el Arte histórica y legal de conocer la fuerza y uso de los derechos Nacional y Romano en España y de interpretar aquel por éste y por el propio origen (Valencia, 1747) de Tomás FERnandez de MESA, donde el puntual recordatorio de los decretos de nueva planta con los que Felipe $V$ "derogó nuestros fueros", y su más sugerente consideración interesada en explicitar que los territorios de la Corona de Aragón se hallan sujetos a las leyes de Castilla "no como de Castilla sino como leyes de su soberano", no impide reconocer finalmente que "no por esto deben los Reinos agregados abandonar sus leyes municipales, porque las comunes no las derogan", apoyándose en su afirmación sobre un entendimiento evidente del fuero como derecho universal, derivación de la costumbre y, en última instancia, del tacitus consensus popuil (Fernández de Mesa, Arle legal, págs. 102/136).

41 Bacallar y Sanna, Comentarios, pág. 145; Belando, Historia Civil, I, págs. $315 / 322$ y 495/499. Para el decreto de 3 de abril de 1711, cfr., Morales Araizabalaga, J., La derogación de los Fueros de Aragón (1707-1711). Zaragoza, Diputación Provincial de Huesca, 1986, págs. 88/92.
} 
bién eran siempre dispersos y ocasionales. La aparente desconsideración de la materia, en este sentido, no era ni mucho menos patrimonio exclusivo de aquellos artisans of glory. Con su específica coloración discursiva catalana, y desde posiciones de filiación dinástica e implicación política bien divergentes, en las voluminosas páginas de los Anales que Feliu de la Peña consagra al tramo inaugural de la contienda civil tampoco se otorga a la de derogación de los derechos territoriales del verano de 1707 ninguna disposición argumental dominante. Al revés, la meticulosidad con la que Feliu pretende retratar la dinámica despótica de vulneración de una constitución de libertades contrasta con el somero apunte en el que se recluye la letra de unos decretos sin duda susceptibles de ser instrumentalizados como símbolo y emblema de la deriva absolutista sobre la que precisamente procuraba llamarse la atención ${ }^{42}$. Era esta, por lo demás, una muesca historiográfica a la que ni tan siquiera escapa Juan Manuel Miñana, aunque fuera otra bien distinta la lectura que luego Mayans sugiere de su obra.

El destierro de la guerra civil y los capítulos como la nueva planta que le son propios hacia periferia historiográfica era aún más sintomático por una cuestión de contexto. Los ecos historiográficos del certamen civil incubado en las entrañas de la incertidumbre sucesoria hispana se difuminaban paradójicamente en un momento en el que muchos autores, de Martí a Mayans, sintieron con mayor o menor nitidez que habian encontrado en el rigor crítico una llave que permitía abrir muchas más puertas de las que a primera vista parecería a los profanos ${ }^{43}$. La vanguardia de esa operación, que descubre en los textos del Marqués de Mondejar y Nicolás Antonio el yacimiento metodológico más fecundo y la simiente de una historiografía de rigurosa impronta y fundamentación documental, habilitaba en el tramo inaugural del Setecientos una atmósfera densa y envolvente para la concepción y tejido de la historia. En ese momento no sólo se funda una Real Academia de la Historia y se editan verdaderos clásicos del género en materia metodológica: sin ir más lejos, el Norte Crítico de Jacinto Segura y la Clave Historial de Enrique Florez. Entonces concurre

42 Narcis Feliu de la Peña, Anales de Cataluña. Barcelona, Juan Pablo Marti, 1709, III, pág. 595. Y sobre los Anaies y su autor, cfr., DURÁN, E., "Narcís Feliu de la Penya, historiador i polític", Afers, 20 (1995), págs. 73/83, ARRIETA, J., "Austracismo ¿Qué hay detrás de ese nombre?", en FERnÁndez ALBALADEJC, Borbones, págs. 191/93, y LLuCH, E., “El programa polític de la Catalunya austracista", en ALBAREDA, Del patriotisme al catalanisme, págs. 149 y ss.

${ }_{43}$ Cfr., MESTRE SAnChis, A., "Crítica y apología en la historiografía de los novatores", Studia historica. Historia Moderna, 14 (1996), págs. 45/62, del mismo, Historiografia, págs. 85 y ss., y Perez Magallón, Construyendo la modernidad, págs. 126 y ss. 
también, y ante todo, un reconocimiento sin precedentes del valor epistemológico primario de la historia para la consideración política y cultural de España y se afirma como valor capital en el mercado historiográfico de la época la imputación expresa a los cronicones fingidos y a las historias fabulosas de las rémoras que obstaculizan la gestación de una depurada historia de España. Pero toda esa función cultural y ese evidente sentido político se condensan en sondeos y prospecciones como la España primitiva de Huerta y Vega, o la España sagrada de Enrique Florez, que conjugando libros, noticias y nostalgias patrióticas aportan unos materiales y sedimentan un terreno mucho más maleable en clave política que el que pudiera derivar de una minuciosa indagación del conflicto civil.

A una historia, al cultivo de la misma, podía entonces preceder una política cultural, su diseño. Un uso y una definición así política de esa historia, que ni parte ni se agota en la materia de la guerra civil pero tampoco se entiende sin ella, cuya naturaleza se vislumbra bien en la cuidadosa elección de los términos con que Mayans despacha la España Sagrada de Florez: "es el Feijoo de los historiadores españoles" ${ }^{44}$. Sin restar trascendencia a la España Sagrada, a Enrique Florez, la clave del asunto parecía ser cosa de Feijoo, de su Teatro Crítico y sus Cartas eruditas. Entre otras piezas, las mismas Reflexiones sobre la historia de Benito Feijoo, aquellas páginas consagradas a marcar y remarcar ei ínfimo grado de ductilidad de las pasiones con el que debe hacer sus cuentas todo historiador, podían ser por tanto más definitorias en el cuadro de la acuñación de una precisa historia de España en la posguerra que los propios textos con los que ella inicialmente se despliega. Frente a la «regla de la Crítica» que esculpe Segura, "los autores contemporáneos a los sucesos son dignos de fe en la historia», conviene recordar que Feijoo interpone toda una retícula de cautelas que le obligan a cerrar las Reflexiones con una precisión en la que subyacen las resonancias de la profunda reflexión animada por la intersección entre tradición libertina y crítica histórica: “No por esto aspiro al pirronismo o pretendo una general suspensión de asenso a cuanto dicen los historiadores" ${ }^{45}$. Lejos del desnudo repudio de la historia, y en el

44 Mestre, Historia, fueros y actitudes poirticas, pág. $35 i$.

45 Segura, Norte Crítico, pág. 433; Fel.joo, Reflexiones, pág. 178. Para el sentido y significado de la precisión de Feijoo, cfr., Comparato, V.I., "La Mothe le Vayer: dalla critica storica al pirronismo", en Gergpry, T., Paganini. G., Pompeo Faracovi, O., y Pastine, D. (edts.), Ricerche su letteratura libertina e letteratura clandestina nel Seicento. Florencia, Olschki, 1981, págs. 259/279, y BiANCHI, L., Tradiziona libertina e critica storica. De Naudé a Bayle. Milán, Franco Angeli, 1989, esp. pp., 45 y ss. Para el intenso debate historiográfico que mantienen Feijoo y Segura, y para su coloración especificamente política, cfr., además del estudio preliminar de BAS MARTín al Norte Crí- 
cuadro de una concepción coherente y trabada que define un «escepticismo rígido" como "delirio extravagante» pero defiende otro "moderado», que identifica como "cautela prudente» ${ }^{46}$, su censura recaía sobre los "hombres llenos de pasiones y pobres de talento" cuya temeridad en la profanación de la historia resultaba ser la antítesis de la "aptitud" y el "talento" del verdadero historiador, rara avis "en quien concurren muchas excelentísimas cualidades, cuyo complejo es punto menos que moralmente imposible". De la política a la historia, toda la copiosa serie de disquisiciones vinculadas a los problemas de su tiempo que incorpora el Teatro Crítico confluyen en la llamada en causa de un canon, un modelo de hombre, singularizado por la integridad moral ${ }^{47}$. La disposición intelectual sobre la que recaía el acento, el juicio recto, no era un sustitutivo del método. Era, en sí, el método, su esencia: "Yo le diré a Vmd. lo que es Arte Crítica y cuáles son sus reglas, empezando por una paradoja. Hablando con propiedad no hay Arte Crítica, ni reglas de este Arte. Lo que se llama Crítica no es Arte sino Naturaleza. Un buen entendimiento justo, cabal, claro y perspicaz es quien constituye un buen Crítico...El que carezca de esta buena disposición intelectual, por más que estudie en la Crítica, sólo por accidente podrá acertar» ${ }^{48}$.

tico, Mestfie, Historia, fueros y actitudes políticas, págs. 60/60, del mismo, Humanismo y crítica histórica en los ilustrados alicantinos. Universidad de Alicante, 1980, págs. 61/98, y SÁNCHEZ BLANco, F., La mentalidad ilustrada. Madrid, Taurus, 1999, págs. 91/97.

46 Benito Jerónimo Feijoo. Escepticismo filosófico, en Teatro Crítico Universal, III, Madrid, Francisco del Hierro, 1729, XIII, 1-2. Y también, para la lectura y reproche del argumento, con significativa alusión al pirronismo de Pierre Bayle, cfr., Andrés PIQUER, Lógica moderna, o arte de ha. llar la verdad y perfeccionar la razón, Valencia, 1747, págs. 67/68: «Pueden los scépticos dividirse en dos clases. Unos fueron scépticos rigidos, otros moderados. Los rígidos eran discípulos de Pirrhón, y por esta razón se llamaban Pirrhonianos, y su sistema pirrhonismo; los moderados siguieron a Sócrates... En nuestros tiempos se han declarado muchos a favor del scepticismo moderado, y en España le han defendido el Dr. Martínez y el P.M. Feijoo. Más yo he notado que son muchos los scépticos que se tienen por moderados y dudan demasiadamente". Por lo que aquí interesa, y para la mención de Martín Martínez, cfr. su Philosophia scéptica (Madrid, 1730), y en especial, pág. 299: "Esta peste de la pasión no sólo inficiona a los necios, sino a los más avisados y doctos".

47 Y cfr., al respecto, sus laudatorios comentarios al Índice de la Filosofia Moral Cristiano-Politica del jesuita Antonio CODORNiu, en cuyas páginas descubre una perspectiva madura y certera que rescata la posibilidad de "conciliar todas las virtudes de la ética cristiana con las más escrupulosas atenciones de la urbana práctica", Cartas Eruditas, III/XXIX (que cito por la edición de Madrid, Imprenta Real de la Gazeta, 1774), págs. 324/27.

48 Benito Jerónimo FEIJOO, "De la Crítica", Cartas Eruditas, II/XVIII (que cito por la edición de Madrid, Imprenta Real de la Gazeta, 1772), págs. 240/1, y cfr. tb. pág. 256, donde la cuestión de la critica retorna una vez más a latitudes pasionales: "Lo cierto es que las prendas intelectuales, sean las que fueren, nunca harán un buen Critico, si faltan otras dos que pertenecen a la voluntad. ¿Cuáles son éstas? Sinceridad y magnanimidad. Si falta la primera el interés de Partido, Comunidad, República o Patria, tal vez el personal, arrastra al escritor a escribir lo que no siente, o por 
Enriquecer el bagaje cultural del historiador, mediante un periplo que conduce de la geografía a la astronomía, de la óptica a la catóptrica, podía ser ciertamente un principio con el que afrontar la depuración de los afluentes que enturbian el caudal de la historia. Dicho con el fervor y la contundencia de la prosa de Feijoo, "para ser historiador es menester ser mucho más que historiador». Las Reflexiones, en ese sentido, no se desvían ni tan siquiera un grado del rumbo marcado por la gran propuesta intelectual que entonces andaba sobre el tapete historiográfico. Mayans, Martín Sarmiento, o el mismo Segura con más timidez, repiten una y otra vez que sólo una educación de ese género era capaz de forjar verdaderos historiadores ${ }^{49}$. Sin embargo la auténtica cruzada cultural del Teatro en materia histórica pasaba por recuperar la virtud y el talante asi moral de un puñado de autores, entre los que destacan con especial fulgor Philippe de Commines, Enrico Catarino Davila y Juan de Mariana, tanto más sintomáticos por cuanto discontinuos e inconexos, autores todos a los que significativamente ya medio siglo antes Gutiérrez de los Ríos y Córdoba reconocia una singular capacidad para inculcar en el hombre práctico, al "hombre señalado para la vida activa», el trascendental "amor de lo honesto" ${ }^{50}$. El tortuoso itinerario biográfico del jesuita toledano no sólo servía además a Feijoo para iluminar el oscuro reverso del laberinto pasional que en su visión envuelve a la historia: "aquellos pocos que se hallan dispuestos a escribirla por la integridad propia, se ven embarazados con la pasión ajena". Elevar a Mariana a los altares historiográficos también le permite aislar el origen de la plaga que en su opinión arruina la práctica totalidad de la tradicional cosecha histórica consagrada a la patria: el sucedáneo política y culturalmente perverso del amor a la patria que Feijoo bautiza como «pasión nacional».

Anticipando ya los nudos argumentales que encauzan las Reflexiones, el volumen tercero del Teatro Critico incluía un discurso, oportunamente titulado Amor a la patria y pasión nacional, alguno de cuyos fragmentos subraya con trazo firme y decidido la secuela historiográfica motivada por

lo menos a callar lo que siente. Si falta la segunda, por convencido que esté de alguna verdad opuesta a la opinión común, por no estrellarse con innumerables contrarios, abandonará aquella por ésta".

49 Cfr., la Prefación de Gregcrio Mayans a las Obras Chronológicas del Marqués de Mondejar (Gregorio MaYANS y Siscar, Obras completas, I, Historia (A. Mestre edt.,).Valencia, Publicaciones del Ayuntamierto de Oliva, 1983 págs. 427/526), y SEgura, Norte Crítico, págs. 163/171. Para Martín Sarmiento, cfr., J. Santos Puerto, Martín Sarmiento: llustración, educación y utopia en la España del siglo xvim. La Coruña, Fundación Pedro Barrié de la Maza, 2002, I, págs. 475 y ss.

50 GutiérRez de los Ríos y Córdoba, Hombre práctico, págs. 147/48. 
aquel «afecto delincuente" que pese a las proclamas retóricas habría terminado por convertir el amor a la patria, la defensa del bien común, en un mero espectro. Desveladas las premisas antropológicas que soportan su apostolado cultural desde la primera entrega del Teatro, sin ir más lejos, cuando al ocuparse de La política más fina sentencia que «el término adonde los hombres caminan es la conveniencia que pretenden", la evaluación de los daños provocados en el ámbito de la historia nacional por aquella pasión que se predica "hija legítima de la vanidad y la emulación", de una "vanidad que nos interesa en que nuestra nación sea superior a todas", resultaba francamente desoladora: "cuando se interesa la gloria de la nación propia apenas se halla un historiador cabalmente sincero". Por si alguien pudiera menospreciar como vacua su afirmación, Feijoo no dudaba además en interponer su experiencia personal: "Apenas hay historiador alguno moderno, de los que he leído, en quien no haya observado la misma inconsecuencia» 51 .

Mayans, algunos años más tarde, con todo el desencanto que deriva de su fallida búsqueda de unos patrones políticos a los que interesar e implicar en sus designios y proyectos culturales, tampoco se deja en el tintero la denuncia del pesado lastre que los imperativos de la política arrojan entre los sedimentos del imaginario nacional: "Yo escribo en tiempo en que las ciencias se ven renovadas en toda Europa y totalmente descaecidas en España, donde suele tenerse por política, introducida por hombres bien hallados en su ignorancia, no hablar de las cosas de la propia nación sino alabándolas» ${ }^{52}$. Es más, fracasada su propuesta, la simbiosis de política e historia que viniera a enriquecer y fertilizar ambos campos, nadie como Mayans captura y denuncia el intencionado desinterés político por la materia histórica que reduce a cenizas una historia de España: "Muchos han deseado la enmienda y perfección de la Historia de España, pocos han practicado los medios convenientes y ninguno ha facilitado con su poder y autoridad tan grande empresa» ${ }^{53}$. Desde posiciones de implica-

51 Tanto La politica más fina (Teatro Crítico Universal, I, Madrid, Francisco del Hierro, 1726, Discurso IV) como el Amor a la patria y pasión nacional (Teatro Crítico Universal, III, Madrid, Francisco del Hierro. 1729, Discurso X), los consulto y cito por la edición del Teatro preparada por Giovanni Stiffoni, Madrid, Castalia, 1991, págs. 124/158 y 235/61.

52 La cita, que es extracto de una carta de Mayans a Francisco Ravago fechada el primero de febrero de 1748, procede de Mestre Sanchis, A., Ilustración y Reforma de la lglesia. Pensamiento político-religioso de don Gregorio Mayans y Siscar (1699-1781). Valencia, Ayuntamiento de Oliva, 1968, pág. 313. Cfr., también, MEstre, Gregorio Mayans y Siscar, págs. 188 y ss.

53 Cfr.. la Prefación de Mayans a las Obras Chronológicas del Marqués de Mondejar, en Obras Complelas, I, pág. 440. 
ción evidente en la política cultural de la época, Feijoo hacía sin embargo extensible la denuncia a otras latitudes nacionales: “No sólo en España quieren que los historiadores sean panegiristas, lo mismo sucede en las demás naciones". Los diques de contención de la historia no podían con la política, con el empuje de la política de la historia y su marea de pasiones. "Apenas pueden hacer otra cosa los pobres historiadores que desfigurar las verdades que no son ventajosas a sus compatriotas. $O$ han de adular a su nación o arrimar la pluma, porque si no los manchan con la nota de desafectos a su patria". Ahora bien, desvelar hasta qué punto resulta maleable la historia en el terreno más espinoso, en los vericuetos de la política, no significa ni mucho menos que Feijoo postulase su abandono. En la fragua de un hombre renovado y moralmente honesto también estaba cifrada la regeneración y así la suerte de la historiografía. Y bien a mano, en el "soberano juicio e inviolable integridad" de Juan de Mariana, estaba el molde y el modelo, el oportuno precedente.

Las hebras políticas del razonamiento historiográfico de Feijoo desde luego no se ocultan en esas páginas. A diferencia sin más de Gregorio Mayans, que firmó o avaló, con prólogos y prefaciones, numerosos textos históricos, y pavimentó con piezas epistolares y proyectos culturales el noviciado entero de los fieles de la crítica histórica, Feijoo no duda en embarcarse en la promoción de una política cultural compatible con los designios dinásticos colocando su prosa al servicio de las Glorias de España ${ }^{54}$. El ascético ejercicio de crítica textual, que rechaza con toda deliberación la posibilidad de abrirse al género de indagaciones que en la España Sagrada de Florez parecían tantearse, induce a Mayans, a la altura ya de 1747, a puntualizar su posición en tan trascendente terreno, con significativa precisión sobre la condición tutelada que la historiografía hispana interesada precisamente por las glorias de España continuaba mostrando en el meridiano del Setecientos: "Aunque soy amantísimo de las glorias de España, y procuro promoverlas cuanto puedo, desestimo las falsas, y entretanto que en España no se permite desengañar a los crédulos, me alegro que haya eruditos extranjeros que lo procuren" ${ }^{55}$. Aplaudir a Mamachi, celebrar sus Antigüedades Christianas para enjuiciar

\footnotetext{
54 Benito Jerónimo Feluoo, Glorias de España, Teatro Critico Universal, IV, Madrid, Francisco del Hierro, 1730. Discursos XIll y XIV (que cito por las Obras escogidas, pags. 194/230. Y cfr., Fernandez Albaladejo, Dinasticismo, págs. 504 y ss.; Alcaraz, Jesuitas, págs. 538 y ss.; STIFFoNI, Verila, págs. 177 y ss.. y MESTRE, Historiografía, págs. 841 y ss.

55 Gregorio Mayans a Enrique Enriquez, Oliva, 30 de enero de 1751, que consulto por el apéndice documental de MESTRE SANCHÍs, Historia, fueros y actitudes políticas, págs. 538/41.
} 
a Florez y cuestionar el rigor de su España Sagrada, "se ha dedicado a pervertir la historia de España», era otra pieza más de un puzzle cuya tonalidad, política e historiográfica, limpiamente se vislumbra ya desde la censura interpuesta por Mayans contra la España primitiva de Huerta y Vega. Los cantos de batalla que entona entonces, "esta obra que se nos presenta con el espacioso nombre de España primitiva, es una España imaginaria, que ni fue, ni pudo ser en la presente providencia", constituyen uno de los eslabones inaugurales de una cadena que, desde el escrupuloso apego a la metodología histórica, desemboca en el desnudo repudio de la alta política de la época que encierra la demoledora respuesta a Burriel recién superado el meridiano del siglo, desestimando su invitación para cubrir en el universo aragonés la labor de aquella comisión de archivos concebida con declarada vocación regalista por Rávago: «En cuanto al registro de este reino, se buscarán y estimarán las cosas favorables al despotismo, no al reino. Lo se bien. Y ojalá que no fuera así» ${ }^{56}$.

El fruto político de un cierto cultivo de la historia, la esperada cosecha de una operación de política histórica, el despotismo, induce así a Mayans a replegarse en la fortaleza de los círculos eruditos en los que mejor podía salvaguardar unos métodos históricos, literarios y jurídicos siempre concebidos como tronco indispensable por el que había de fluir la savia de una nueva cultura. Su inquebrantable defensa del valor epistemológico de la historia para la consideración del derecho al fin y al cabo recorre idéntico camino. En la estela de la «necesidad de unas Instituciones del derecho patrio", apuntada en las páginas de los Pensamientos literarios que dedica y dirige desde su posición de bibliotecario real a Patiño, y aderezada con piezas de combate como su crítica a la Historia del Derecho Real de España de Prieto y Sotelo, la fallida tentativa de depuración histórica del derecho patrio que promueve en su Carta escrita al Dr. Josef Berni sobre el origen y progreso del Derecho Español lo conduce a ios arrabales de un prolongado debate animado por la reinterpretación histo-

56 Crr., per un lado, la Censura de la España primitiva de Francisco Javier Huerta y Vega (1739), en Mayans, Obras completas, I, págs. 261/305, con las consideraciones al respecto de Antonio MESTAE (Ilustración, págs. 123/129, y Gregorio Mayans, págs. 124 y ss.) y las sugerentes precisiones de Stiffonl (Verita, págs. 224/240); y por otro, Gregorio Mayans y SiscaR, Epistolario, II. Mayans y Burriel, Valencia, Ayuntamiento de Oliva, 1972, Mayans a Burriel, 16-I-1751, cuyo contexto, la operación de política histórica de cuño regalista, puede reconstruirse merced a GómEZ, M., "Crítica histórica y archivos: el caso de España en el siglo XVIIl", en Historia, Instituciones, Documentos, 12 (1985), págs. 199/231, esp. págs. 218 y ss.; Mestre. Historia, págs. 297/302, y BARAS ESCOLÁ, F., “Política e historia en la España del siglo xvill: las concepciones historiográficas de Jcvellanos", en Boletín de la Real Academia de la Historia, 191 (1994), págs. 295/385, esp. 321 y ss. 
riográfica del derecho nacional e interesado, con inconfundibles aromas políticos, en rastrear la posible existencia de un derecho propiamente español cifrado en una antigua constitución gestada autónomamente en Castilla ${ }^{57}$. Ante ese panorama, en el que pasa por español lo que como leyes fundamentales debía sondearse en Castilla, Mayas deriva hacia iniciativas - comenzando por la recopilación de materiales para una Historia del derecho municipal de Valencia, o la encarecida demanda para que José Finestres aportase una Historia del derecho de Cataluña- tan atentas como sensibles al tratamiento de la pluralidad jurídica de la monarquía y asi a una cierta memoria histórica de la composición plural de la misma que veía naufragar en los sinuosos meandros del proceso de construcción historiográfica de un derecho y una politica que pudieran predicarse como propios de la patria: "Los castellanos quieren quitarnos aún la memoria de nuestra antigua libertad $» 58$.

La operación de política histórica en la que por el contrario Feijoo se empeña al «mostrar a la España moderna la España antigua» procuraba despejar históricamente las muescas sobre las que asentar las señas de identidad de una comunidad política en cierto modo huérfana de referencias tras la contienda civil del amanecer del Setecientos. Esquivando el elevado peaje que luego propugnan Mayans o Burriel, el sondeo, recuperación y fijación del cuerpo de textos, impresos y manuscritos, consagrados a la historia civil y eclesiástica de España, Feijoo se limita a levantar acta de lo que entiende como paradigma social: aquel reducido espectro de valores sobre los que había de moldearse la muesca definitoria de aquella comunidad. Esa labor artesanal, antes que histórica políticamente concebida, era la que en verdad interesa encauzar al autor del Teatro. Entre el "amor a la libertad" y el "celo de la religión", en la genética hispana se descubría asi la posición dominante y definitoria del «espíritu marcial", cerrándose drástica e intencionadamente el recorrido panorámico por las "glorias de los progenitores" en el momento en el que el destino de la monarquía se vincula a la Casa de Austria. Que tal momento - final

57 Cfr., Vallejo, De Sagrado Arcano a Constitución esencial, págs. 474 y ss.; PoRTillo ValDES, J.M., Revolución de nación. Origenes de la cultura constitucional en España, 1780/1812. Madrid, Centro de Estudios Políticos y Constitucionales, 2000, esp. cap. 2, y el estudio preliminar de Pablo Fennández Albaladejo a Pedro José Pérez Valiente, Derecho Público Hispánico. Madrid, Centro de Estudios Politicos y Constitucionales, 2000.

58 Cfr., Mayans a Asensio de Sales, 25 de abril de 1763, que puede consuitarse, para así mejor reconstruir su contexto, en LóPEZ, F., Juan Pablo Forner y la crisis de la conciencia española en el siglo xvil. Salamanca, Junta de Castilla y León, 1999, pág. 104, y en MESTRE SANCHis, Historia, fueros y actitudes políticas, pág. 283. 
o inicial, según se mire- representase una cesura en la evolución de la identidad hispana veladamente parecía insinuarse, aunque Feijoo, mas preocupado por el período que se abría que por el que se cerraba, se abstiene de recorrer aquella senda, ya abierta durante la contienda civil, cuyo destino es el ajuste de cuentas con la anterior dinastía. Bajo la declarada pretensión de rectificar una degradada imagen cultural y política de lo hispano que circula por el foro erudito europeo, el dudoso rigor crítico con el que Feijoo retrata las glorias de España, y que merece la oportuna amonestación de Mayans ${ }^{59}$, no parece gratuito ni casual. Lejos de promover una ajustada y puntual reconstrucción del devenir histórico de la nación, lo que el benedictino procura, en el preciso momento en el que cae el telón de la confrontación civil hispana y dinástica europea que motiva la sucesión de la Corona católica, es la fijación históricamente abstracta de los rasgos definitorios de un carácter, con su correspondiente traducción en un vasto catálogo de virtudes, sobre los que aquilatar y pulir una identidad hispana acorde con los nuevos tiempos. La propia comprensión de la utilidad política de la historia, en el seno de esa operación, experimentaba asi una profunda transformación frente a los postulados tradicionales: "por lo que mira a los varios expedientes que presentan las historias y con que los políticos de otros tiempos lograron los fines a que aspiraban, juzgo que más embarazan que sirven" ${ }^{60}$.

Buena parte del discurso que dedica a los "Libros políticos" testimonia y manifiesta, ratifica y amplia, esa noción en la que se condensa y contiene una decisiva reformulación del topos de la historia magistra vitae radicalmente opuesta de la que pudiera insinuarse en las Memorias del Conde de Robres ${ }^{61}$. Empeñado además en disociar el grano de la paja, antes que unas

59 Mestre Sanchis, A., "Correspondencia Feijoo-Mayans en el Colegio del Patriarca», en Anales del Seminario de Valencia, 8 (1964), págs. 173/179.

60 Benito Jerónimo FelJoo, Libros políticos, en Teatro Crítico Universal, Madrid, Viuda de Francisco del Hierro, 1733 (que cito por la edición preparada por Giovann Stiffoni para Castalia), pág. 330.

61 FElJOO, Libros politicos, pág. 318: *Hállanse a la verdad libros llenos de documentos políticos, y las historias proponen numerosos ejemplares que aún son más instructivos que los documentos, porque representan más sensible la aplicación a la práctica según las circunstancias ocurrentes. Mas mirándolc con sutil reflexión, esta instrucción es sólc aparente, que hace alguna figura en la te. oría y es inútil para la práctica. La razón es porque cuando quiere ponerse aquellos preceptos en ejecución, riunca concurre en el hecho el mismo complejo de circunstancias que se halla en el libro. ¿Nunca? ¿No cabe la posibilidad, que uno u otro raro acaso traiga las mismas? No por cierto. Siempre, de absoluta necesidad, ha de faltar una, que es la de la persona que obra". Y por aquí la ruptura es evidente, sin ir más lejos, con el hombre práctico de Gutiérrez de los Ríos y Córdoba con el que tanta sintonia venia insinuándose (cfr., GuTiÉRREZ DE los RIOA y CóRDOBA, Hombre práctico, pág. 243 — «lo que debe servir a nuestra instrucción y enseñanza es verdaderamente la reflexión de los he- 
falsedades elevadas al rango de historia, el expurgo más urgente que en la visión de Feijoo convenía acometer se orientaba así hacia los dominios de la psicología en los que hunde sus raíces el imaginario nacional. Si las glorias de España, en ese sentido, servían para sumar, la Antipatía entre españoles $y$ franceses ${ }^{62}$ permitía descartar muescas que tradicionalmente habian venido jugando un papel decisivo en la comprensión del carácter hispano. Presentar "las voces generales de simpatía y antipatía» como recurso lícito en la filosofía pero ilicito en la política, por los «funestos efectos" derivados de su incorrecta consideración y aplicación, buscaba desempolvar la imagen de una antigua correspondencia entre Francia y España resquebrajada por la incorporación de concepciones propiamente aragonesas al imaginario hispano en los momentos de afirmación católica de la monarquía y ensombrecida después por unas motivaciones antes dinásticas que nacionales: «Algunos quieren que el dominio de los austriacos haya introducido en España la oposición a los franceses. Yo consentiré en que la aumentó, mas no en que la dio origen....Así, juzgo que considerada esta ojeriza en su primer estado no la heredaron los españoles de los alemanes, sino los castellanos de los aragoneses". $Y$ al hilo de ese preciso argumento, con las pasiones asumiendo así un papel capital también en la historia, en el decurso histórico y no sólo en el discurso historiográfico, Feijoo podía filtrar y deslizar una intencionada interpretación y un tan interesado como univoco cauce de interiorización y comprensión del traumático certamen civil incubado en el ocaso del Seiscientos y alumbrado con el alba del Setecientos: «Tanto ha ocupado los ánimos la persuasión de la congénita discordia de las dos naciones que aún cuando dispuso el Cielo que la Augusta Casa de Francia diese rey a España, muchos pronosticaban que nunca se avendrían bien. De hecho, aún después por algunos años, experimentamos los funestos efectos de esta aversión". Aquí, elocuentemente, comienzan y concluyen las consideraciones y los comentarios de Feijoo sobre la guerra civil en el dilatado cuerpo de una obra enciclopédica que recibe los calurosos elogios de Nicolás Belando y prodiga alabanzas no menos fervorosas a Enrique Flórez ${ }^{63}$.

\footnotetext{
chos pasados, comparándolos a los presentes para poder hacer sobre ellos más atenta reflexión y, supliendo con esto a nuestra experiencia propia, acertar mejor en nuestras operaciones"- y los comentarios de Pérez MAGallon, Construyendo la modernidad, págs. 163 y ss.

52 Benito Jerónimo Felsoo, Antipatía de españoles y franceses, en su Teatro Crítico Universal, II, Madrid, Francisco del Hierro, 1728, Discurso IX (que manejo también por la edición de Stiffoni para Castaiia), págs. 167/197.

63 Crr., el prólogo de Nicolás DE JEŚ́Js BELANDo en la primera entrega de su Historia civil y Benito Jepónimo Fel.joo, "Sobre la España Sagrada del Rmo. P.M. Fr. Enrique Flórez", en Cartas eruditas y curiosas, III (que cito por la edición de Madrid, Imprenta Real de la Gazeta, 1774), págs. 390/393.
} 
Dedicado Enrique Flórez, en palabras de Feijoo, a «romper las densas nieblas de la antigüedad", y ocupado Nicolás Belando, según su propia confesión, en la glosa laudatoria de las gestas del monarca, de un monarca que "no necesita mendigar elogios a los tiempos pasados", la mixtura entre una historia nacional antigua y una historia rabiosamente presente y dinástica, que bendice el Teatro crítico, generaba un ángulo muerto de preocupación histórica cuya magnitud mayúscula encierra una evidente virtualidad política y un descuido y abandono no menos premeditado en el cultivo de aquel género de memoria histórica como el que pudiera interesar a Mayans al ofertar a Lynden la edición del De bello rustico valentino ${ }^{64}$. En este sentido, y en ese contexto, el vínculo entre la recuperación del texto de Miñana y la firme determinación de mantener viva la llama de esa memoria, la de una antigua libertad, no podía ser más evidente ni menos intericionado. Mayans conocía además bien las últimas tendencias del laboratorio político vinculado a la Corte cuya vertiente historiográfica mostraba un renovado interés por unas antiguas libertades que no eran las de Aragón sino las de Castilla. El estado de la cuestión, en ese orden de cosas, lo podía proporcionar Andrés Marcos Burriel, que al tiempo de promocionar la idea de una necesaria unidad de la monarquía por encima de diferenciaciones forales territoriales, y de promover así la concepción unitaria de «un cuerpo de nación estable y firme", venía también madurando un proyecto historiográfico que le conduce a descubrir las esencias forales de la misma Castilla como fundamento de un derecho español. $Y$ en ese preciso horizonte político de contemplación histórica la liquidación de aquellas antiguas libertades valencianas que tanto importan a Mayans solo interesaban como ilustración de una modalidad de imposición de las leyes castellanas en la que se podía reconocer la degradación de una original naturaleza constitucional y política de Castilla cuya recuperación se propugna: "Pero nuestro derecho de Castilla, lejos de darse como favor a provincias beneméritas, se ha dado como castigo a provincias conquistadas a quienes se derogaron sus Fueros" ${ }^{65}$. Aunque fuera como contrapunto, uno de los motivos y referentes capitales en el intenso debate previo a la unión de

64 Ctr., Fernández Albaladejo, Dinastismo, págs. 504/515; Stiffoni, Verita, págs. 86/156, y Mestre Sanchis, A., "Reflexiones sobre el marco político y cultural de la obra del Padre Feijoo", en Bulletin Hispanique, XCl (1989), págs. 295/312. La cita de BELANDo en Historia Civil, I, Dedicatoria.

${ }_{65} \mathrm{Cfr}$., Cartas eruditas y críticas del P. Andrés Marcos Burriel, de la extinguida Compañia de Jesús, Madrid, s.a., págs. 45 y ss., y Andrés Marcos Burriel, Intorrne de la imperial Ciudad de Toledo al Real y Supremo Consejo de Castilla sobre igualación de pesos y medidas en todos los Rejnos y Señorios de su Majestad según las leyes. Madrid, 1758 (que manejo por la edición de J. Cobo. Toledo, 1991), págs. IV y ss. 
Escocia e Inglaterra en 1707, el ius latii, el ius deseado por las provincias del imperio romano como distintivo de la pertenencia a la mejor de las condiciones en él, asomaba asi paradójicamente en latitudes hispanas en la estela de una cierta concepción histórica de Castilla y su derecho que Burriel, desde el meridiano del Setecientos, procura transmitir. Ese era el signo de los tiempos. Y ese era el más claro indicio de la altura y el talante de la reflexión sobre la nueva planta, la prueba quizás más evidente de su progresivo confinamiento y depreciación en el cuerpo de cuestiones que se entienden mayores.

Con una visión del problema que simultáneamente es una visión de la historia, de la precisa historia que Gregorio Mayans echa en falta en su tiempo, editar el De bello rustico suponía en términos políticos algo más que la mera adhesión a unos principios esenciales como la actitud ante el objeto de estudio o el modo de comunicarlo. Ni los textos se entienden sin los contextos, ni los hechos sin las circunstancias. $Y$ lo que Miñana alcanza de la mano de Mayans en 1752 era el preciso rango en el cultivo de la memoria que tanto deseaba el Conde de Robres para sus Memorias. Además, justo en ese momento el rastreo de las antiguas libertades de Castilla, que no las de Aragón, otorgaba un notable protagonismo a la cuestión que en visperas del Act of Union de 1707 se configura como el verdadero nudo gordiano de un magno debate: el desencuentro profundo entre unos unionistas que, amparados en los planteamientos de Hugo Grocio sobre el episodio de incorporación de los Sabinos al imperio romano, promueven el entendimiento de la unión como comunicación de leyes que lejos de significar la entrega incondicional de la soberanía equivale a su trasferencia en un nuevo cuerpo político, y aquellos otros que, como Andrew Fletcher, procuran neutralizar semejante línea argumental recordando que en ese episodio la consideración propia de una conquista precede a la posterior oferta de incorporación ${ }^{66}$. $Y$ al fin y al cabo, si Melchor de Macanaz es el nombre y el hombre que en 1707 promueve la imposición de las leyes de Castilla en la Corona de Aragón sobre la imagen de la Jerusalén conquistada ${ }^{67}$, la única lectura de la nueva planta del continente

56 Cfr., Robertson, J., "Andrew Fietcher's vision of Union", en MASON, R. A. (edt.), Scotland and England, 1286-1815. Edimburgo U.P., 1987, págs. 213/14, y del mismo "Empire and Union: two concepts of the early modern political order" $y$ "An elusive sovereignty: the course of the Union debate in Scotland, 1698/1707", reunidos en ROBERTSON, J., A Union for Empire: Political thought and the British Union of 1707. Cainbridge U.P., 1995, págs. $3 / 36$ y 198/227 respectivamente, y ARMITAGE, D., The ideological origins of Brithish Empire. Cambridge U.P., 2000, págs. 161 y ss.

67 Cfr., la memoria que Melchior de Macanaz compone y traslada en mayo de 1707, por medio de Tobias de Bourck, a Miche! de Amelot (Archives du Ministère des Affaires Etrangères. Corres- 
de España en cuya representación castellanos y británicos tenian su papel bien definido era la que bajo forma de Memorias manuscritas el Conde de Robres deposita en una gabeta en la primavera de 1709.

II. Ante el texto de los decretos de nueva planta para el gobierno político y económico de Aragón y Valencia del verano de 1707 las Memorias del Conde de Robres evocan el unionismo británico y estigmatizan el posicionamiento castellano. Recién inaugurado el fuego cruzado de la recomposición de los derechos hispanos, interesa a su reconstrucción de unas guerras civiles de España una personal interpretación de la unión de 1707 entre Escocia e Inglaterra, contemplada y contextualizada intencionadamente en el horizonte de unas guerras civiles británicas que también responden, tras la muerte de Guillermo III, a la modalidad de una guerra de sucesión ${ }^{68}$. Omitiendo mayores precisiones sobre el intenso y dilatado debate que desemboca en 1707 en la acuñación de una fórmula capaz de asegurar la unión estable entre las dos principales entidades del archipiélago, y de salvaguardar primeramente la concepción y condición de Inglaterra como Imperium ${ }^{69}$, el excurso proporciona al autor la posibilidad de presentar un modelo de «convención nacional» radicalmente opuesto al animado en idénticas fechas en latitudes hispanas. Desvelada la clave castellana de reintegración con la que aspiraba a neutralizarse la secesión derivada de un conflicto de sucesión, el referente del unionismo británico le habilitaba ante todo $-y$ aún operando desde el sesgado entendimiento del episodio - en el reconocimiento de una formula que se entendía exenta de motivo y "razón para que se crea sepultado el nombre de escocés o el de inglés en la unión de las dos naciones, antes la hay para entender ambos confundidos en el de británicos, nombre antiguo común de los dos pueblos, no llamándose el parlamento unívoco de Inglaterra, ni de Escocia, sino de la Gran Bretaña». De esa «igualdad en el tratado" entre "naciones que aman fuertemente las antigüedades patrias",

pondance Politique: Espagne - AAE. CP(E) - vol. 168, fols. 68/69), y también del propio Melchor de Macanaz, para este preciso argumento y razonamiento, Regalias de los Señores Reyes de Aragón (que cito por la edición de Joaquín Maldonado Macanaz, Madrid, Imprenta de la Revista de Legislación, 1879), pág. 99.

68 Cfr., Goldie, M., "Divergence and Union: Scotland and England, 1660/1707 ", en BradSHAw, B., y MORRILL, J. (edts.), The British Problem. State formation in the Atlantic Archipelago, 1534/1707. Londrés, MacMillan, 1996, págs. 220/245.

69 Cfr., Robertson, Union for Empire, passim; Pocock, J.G.A., La ricostruzione di un impero. Sovranita britannica e federalismo americano. Manduria-Bari-Roma, Piero Lacaita, 1996, págs. 39/54; e ISTVAN HONT, "Free trade and the economic limits to national politics: neo-Machiavellian political economy reconsidered", en DuNN, J., The economic limits to modern politics. Cambridge U.P., 1990 , págs. $41 / 120$. 
y del papel que frente a la dinastía podía corresponder al parlamento como elemento integrador ${ }^{70}$, convenía dejar constancia en un texto compuesto entre 1708 y 1709 , e interesado en las guerras civiles de España, pues apuntaba formulas de resolución al encuentro entre socii que pudieran propugnarse para Hispania, aún desde la certeza de su absoluta postergación: «no ha faltado quien discurriese que fuera más del servicio del señor Felipe $\mathrm{V}$ el reducir a unidad sus dominios por ese medio que por el de su proclama de 1707 ${ }^{71}$.

Frente a la igualdad británica dicha proclama optaba, en el lenguaje del Conde de Robres, por la reducción: "univocar el gobierno con Castilla» ${ }^{72}$. En la política de la nueva dinastía, en su declaración de intenciones bajo forma de nueva planta, descubría un aragonés de filiación borbónica la pretensión monárquica de relacionar los territorios en términos políticos y jurídicos, con la consiguiente cancelación de la propia cultura tradicional en la que se comprendian unas reglas de relación de territorios con derechos particulares y sin derecho territorial común. Caben por supuesto y comparecen juegos retóricos que procesan en términos bien dispares la intervención del príncipe sobre los derechos constitutivos de territorios así distintos. Destaca con luz propia la graciosa igualación que diría el embajador francés Michel Amelot: «S. Majestad le ha dispensado -y se dirige a la ciudad de Valencia - un singular favor en igualarle con su amada Castilla, concediéndole todas las leyes, fueros, privilegios y costumbres que a costa de tantos, tan antiguos méritos y servicios, ha adquirido " ${ }^{73}$. Pero el Conde de Robres no parecía dispuesto a secundarlos. La derogación de unas leyes patrias y la liquidación de unas libertades, la solución

\footnotetext{
70 Para la disyuntiva y sus implicaciones, cfr., EASTWOOD, D., JOHN, M., y Brocki.ISS, L., "Fron dynastic union to unitary State: the European experience", en EASTWOOD, D., y JOHN, M. (edts.), A Union of multiple identites. The British Isles, c. 1750-1850. Manchester U.P., 1997, págs. 193212, y para la visión y comprensión de la Unión de 1707 "within a European setting", y así como "the British variant of a wider pattern", cfr., BOBERTSON, J., "Union, state and empire: the Britain of 1707 in its European setting", en STONE, L. (edt.). An Imperial State at War: Britain from 1689 to 1815. Londrés, Routledge, 1994, págs. 224/257.

7 CONDE DE Rogres, Guerras civiles, pág. 384.

72 CONDE DE Robres, Guerras civiles, pág. 366.

73 Carta de Michel Amelot a la Ciudad de Valencia, 21 de setiembre de 1707, que consulto y cito por MANCEBO, M.F.. "El primer ayuntamiento borbónico de la Ciudad de Valencia", Estudios de Historia de Valencia. Valencia, Diputación, 1978, pág. 301. Para la gestación de los decretos de junio y julio de 1707, cfr., INUAFFITEGUI, J.M., “1707: la fidelidad y los derechos", en FERNÁNDEZ ALBALADEJo, Borbones, págs. 245/302; Mcrales ARRIzABalaga, Derogación de los fueros de Aragón, passim, GAY EsCODA, J.M., El corregidor a Catalunya. Madrid, Marcial Pons, 1997, págs. 33 y ss., y GIMÉNEZ LOPEZ, E., Gobernar con una misma ley. Sobre la nueva planta borbónica en Valencia. Universidad de Alicante, 1999.
} 
estricta y rigurosamente niveladora arbitrada en 1707 para el universo aragonés y valenciano, recibe en su discurso otra lectura bien distinta: "reducida toda esta península a la unidad que tuvo en los tiempos de los godos, no habiendo ya otro nombre que el de españoles" ${ }^{74}$. La igualación en materia jurídica se entendía así como liquidación de la identidad política de unos territorios. Frente a los supuestos de fondo que rigen the invention of Britishness, que infunden la concepción de una new British nation a partir del Act of Union de 1707, y a diferencia del diseño de una arquitectura identitaria en clave imperial superpuesta a unas older nations, la Nueva Planta podía desatar así en el ámbito aragonés la conciencia de una traumática crisis de identidad ${ }^{75}$.

El motivo central de reflexión de las Memorias no se recluye por tanto en la superficie del texto, en la letra de los decretos que articulan un nuevo modelo de dominio político y sellan una reforma de la geografía constitucional hispana. Robres inscribía y describía ya de entrada como registro metodológico de estudio y análisis un sutil enlace entre la materia jurídica y la identidad territorial. En cierto modo, así se ubica el dato relevante en la intención de la política de nueva planta y su determinante incidencia sobre un terreno - considerado previo al propiamente jurídico- y sobre una dimensión cultural e identitaria así tenida por básica. Desde ese posicionamiento, y desde ese convencimiento, era lógico que se buscasen otros espejos y modelos en que ver reflejada una composición más concordante con lo que se pudiera tener por histórico. Revelar una particular repugnancia hacia la vocación uniformadora que suponía la demolición de unos ordenamientos privativos y su pretendida sustitución por la tradicional constitución política castellana adoptada como modelo, enjuiciarlo en suma como "odiosa mudanza", lejos de constituir el cierre del discurso se adoptaba en esa perspectiva como premisa de partida. Ese era uno de los empeños mayores de las Memorias, consignar para una historia de las guerras civiles de España una particular concepción del fondo y la forma de unos decretos y una política de nueva planta.

\footnotetext{
74 CONDE de RoBRes, Guerras Civiles, pág. 367.

75 Cfr., para la vía imperial que rige la demarcación y formulación de una identidad británica Colley, L., Britons. Forging the Nation, 1707-1837. New Haven, Yale U.P., 1992, esp., pags. 6/9 y 374 , con posibilidad de rastrear la raiz confesional que rige, con Francia como contrapunto, un "oppositional model of identity-formation", merced a HELGERSON, R., Forms of Nationhood. Chicago, University of Chicago Press, 1992. Para el caso francés, cfr., los balances historiográficos que sobre la cuestión firman ENGLUND, S., "The Ghost of Nation Past», Journal of Modern History. 64 (1992), págs. 299/320, y BELL, D., “Aecent Works on Early Modern French National Identity", Journal of Moder History, 68 (1996), págs. 84/113
} 
Interesando el predicado de unos principios y el rigor de la predicación - «si la resolución era por sí misma sumamente dura, el estilo del decreto fue durísimo" - la posibilidad de un viraje de la política real que viniera a suavizar posiciones y corregir la tendencia era algo que significativamente ni tan siquiera contemplaba el relato de Robres. Sobreentendía que el tiempo y el momento para la expresión de la piedad del soberano, bajo forma de revocación del decreto abolicionista, ya había concurrido sin demostrar Felipe $V$ ninguna voluntad de mover pieza en esa dirección. Cuestión al fin y al cabo derivada de una crisis de sucesión, el nacimiento del príncipe Luis Fernando constituia en su interpretación el escenario decisivo para descubrir el posicionamiento de los protagonistas y clarificar así la línea de orientación política de la nueva dinastía ${ }^{76}$. Considerando entonces el episodio como "la ocasión de revocar los decretos», y de hacerlo además informando de la muesca virtuosa del monarca, "después de haber amagado con lo más fuerte de su justicia», su resolución servía a Robres para fundamentar el poso de escepticismo que determina la fisonomía de las Memorias, concebidas abiertamente desde la contemplación de un horizonte en el que la pérdida de unos ordenamientos territoriales se antojaba irreversible. En el abandono de Felipe $\mathrm{V}$ como interlocutor, y de la piedad del soberano como referente de trabajo, también cotizaba sin embargo tan reconocida como decisivamente otro factor: la suerte corrida por la primera pieza articulada por la cultura foral en defensa de su ordenamiento propio: el Memorial que Josep Ortí redactaba en Valencia en agosto de 1707 y cuya letra y argumento constitucional Robres conocía bien. El Memorial constituía una apelación directa a la gracia del monarca: «sea de su

76 E interesa en este orden de cosas el tratamiento que Felipe $V$ termina confiriendo a la sucesión del reino como asunto doméstico y asi estrictamente familiar, con implicaciones patrimoniales evidentes. Cfr., VIEJO YharRASSARRY, J., "Las Hijas de Salphad. Controversia dinástica y trastondo confesional en la Monarquía Católica", en Fernández ALBALAdEJo, P. y OrTEGa LóPEZ, M. (edts.), Antiguo Régimen y Liberalismo. Madrid, UAM/Alianza, 1995, 3, págs. 379/387. Y cfr., la carta de Luis XIV a Michel Amelot del 4 de septiembre de 1707 para una valoración política y dinástica del nacimiento del príncipe que podía ya condensarse en la elección de su propio nombre: "Vous consulterez de ma part le roy mon petit-fils sur le nom qu'il veut qu'on lui donne alors; le mien n’a jamais été porté par aucun roy d'Espagne. Il est à examiner si, en le donnant à l'heritier présomptif de la couronne monarchique, les inalintentionnés pourroient se servir de ce pretexte pour exciter les peuples, et pour les persuader que je méprise la nation en donnant à celui qui va régner sur elle un nom qui est devenu, en quelque façon, particulier au roy de France. On peut considérer, d'un autre còté, que le nom de Phiiippe ni celui de Charles n'avoient jamais été portés par aucun roy d'Espagne avant que la maison d'Autriche en ait occupé le trône. If est naturel qu'un prince descendant de Saint Louis, né le mème jour de sa feste, porte le nom d'un saint qu'il fera gloire de compter au nombre de ses ancêstres" (BARON DE GIRARDOT, Correspóndanse de Louis XIV avec M. Amelot, son ambassadeur en Espagne, 1705/1709. Nantes, Imprimiere Merson, 1864, I, págs. 232/33). 
Real servicio conceder la gracia y merced de mantener y no mudar las Leyes municipales que repetida premeditación adaptó a lo peculiar de este país; los privilegios que tantos gloriosos progenitores de $\mathrm{V}$. Majestad concedieron; estilos que proporcionó la aptitud de los genios; costumbres que perfeccionó la práctica de los tiempos; y el Gobierno que al amor de la patria ha de ser de tan sensible dolor ${ }^{77}$. Pero la composición del texto, lejos de modificar el rumbo de una política, conducía directamente a Ortí al presidio de Pamplona clarificando el panorama. Dando entonces por supuestas las reglas con las que se configuraba el debate, el discurso de Robres rompía amarras incorporando como premisa de partida el núcleo del planteamiento de Orti, su fórmula y pretensión de desmontar la ratio que informa la nueva planta del edificio monárquico ubicando la clave del más reciente devenir de los territorios forales en el ámbito puramente militar y no en los dominios de la fidelidad.

Compartiendo idéntico registro interpretativo y presupuesto de partida con el Memorial, pero incidiendo en el posición de unos órganos de representación de la comunidad territorial, las Memorias introducian un vocabulario de mayor alcance político y más profunda significación constitucional: "solamente puede llamarse rebelde, y tratarse como a tal, el reino que falta a su soberano, cuando no sólo el pueblo sino los que lo representan, esto es, los que componen sus estados, le niegan la obediencia, sin que para eso sea requisito el congreso de las Cortes" ${ }^{78}$. La desautorización de una premisa crucial en la arquitectura del decreto, «que el delito de infidelidad de estos reinos trajese consigo el reato de perder los privilegios", ya se articulaba así novedosamente en sus páginas mediante la incorporación de un motivo de estructura constitucional: la comprensión corporativa de las diputaciones de la Corona de Aragón como cuerpos que representan a los Reinos ${ }^{79}$. Presente en Aragón pero cortocircuitada

77 Cfr., PESET, M., "Notas sobre la abolición de los fueros de Valencia», Anuario de Historia del Derecho Español, 42 (1972), págs. 657/715, y esp. págs. 694/713 donde se reproduce el $M e$ morial de Josep Orti. Para el encuadre de la semántica política del Memorial y su invocación del amor a la patria, cfr., CASEY, J., "Patriotismo en Valencia durante la edad moderna», KAGAN y PARKER, España, Europa y e! mundo atlántico, págs. 251/278, y del mismo, "Una libertad bien entendida": los valencianos y el estado de los Austrias", Manuscrits, 17 (1999), págs. $237 / 252$.

78 CONDE DE Robres, Guerras Civiles, pág. 371.

79 Vinculado al entendimiento ya clásico de los "deputats" comc "pares de la patria" -y cfr.,el Informe de verdaderas noticias per 10 mayor benefici, quietut y gloria de Catalunya, BC. $F$. Bon., 4655, pág. 12-- la llamada en causa de unas asambleas de estados que representan al reino anticipa alguno de los principales argumentos constitucionales que la literatura política catalana despliega en la encrucijada de 1713: cfr., Lealtad catalana purificada de insidiosas calumnias entre llamas de sufrimientos, en el crisol de la constancia, esmaltada con lo heroico de la resolución de defenderse Cataluña por el Rey y por la Patria. Villafranca, 1714 (BC. F.Bon., 703), 
en otras latitudes de la monarquía ${ }^{80}$, invocar como supuesto cardinal de la reflexión la representación del regnum, la concurrencia a la representación de todo el cuerpo de nación, de los diferentes status que la componían, suponía toda una declaración de principios y una no menos puntual confesión de lengua y cultura constitucional que automáticamente imprimía al debate una renovada envergadura. La definición misma de una modalidad de representación ${ }^{81}$ como cuestión previa y decisiva implicaba al menos el reconocimiento de unas capacidades políticas, y la asimilación de unos presupuestos internos de composición, que la nueva dinastía no parecía precisamente dispuesta a procesar. Más bien, con todo un cruce y confluencia de estímulos como telón de fondo, y aparejada a la cancelación del derecho propio, la liquidación de toda representación concurrente de la comunidad territorial se descubría así como perfil capital en la configuración resultante de la nueva planta.

El balance de Melchor de Macanaz sobre el tortuoso devenir de la Junta o Tribunal del Real Erario creada para Aragón a principios de 1711, y cuya composición estamental reproducía la lógica tradicional que había venido guiando la fisonomía de las Cortes y la Diputación, ya informaba elocuentemente de las decisivas limitaciones que la presencia y comprensión de una auténtica communitas regni imponian en el despliegue de la política de nueva planta: «El fin que tuvo S.M. para formar esta junta fue

pág. 37 (“Sóio las resoluciones que se toman en Cortes de un Reino o provincia son las que se atribuyen a la Nación, y por ellas se merece aquella el crédito o el descrédito, a distancia de las resoluciones particulares, que estas o acreditan o afrentan un territorio, o una familia, pero no una Nación, que sólo se representa en sus brazos unidos"), y Crisol de Fidelidad. Manifestación que hace el Principado de Cataluña de las causas de alta congruencia que le han obligado a tomar las armas para defender su libertad. Barcelona, Rafael Figueró, 1713, pág. 4 ( $:$ El Principado de Cataluña....está representado en la Ciudad de Barcelona, que es su Cabeza, Diputación y Brazo Militar, los cuales juntos y congregados forman y componen, resuelven y decretan el todo de lo que concierne a la utilidad y major beneficio comün). Cfr., también, CASTELLvi, Narraciones Históricas, III, págs. 813/15.

8o Cfr., Fernández Albaladejo, P., "Cortes y poder real: una perspectiva comparada", en Fragmentos de Monarquía. Madrid, Alianza, 1992, págs. 300/324; HeSPANHA, A., "As cortes e o reino. Da uniâo à restauraçâo", Cuadernos de Historia Moderna, 11 (1991), págs. 21/56, y CLAVERO, B., Institución histórica del derecho. Madrid, Marcial Pons, 1992, págs. 47 y ss.

81 Para el sentido de curaduría y tutela mediante el que puede captarse la significación profunda de la función representativa en la cultura altomodeina, cfr., FERNANDEZ ALBALADEJO, P., "La representación politica en el Antiguo régimen". El Senado en la historia. Madrid, Secretaría General del Senado, 1998, págs. 53/81; Dusso. G., "La rappresentazione e l'arcano dell'idea", " Centauro, 15 (1985), págs. 40 y ss.; FISICHELLA, D., La rappresentanza política. Milán, Giuffrè, 1983, esp. págs. 7 y ss., PITKIN, H.F., El concepto de representación. Madrid, Centro de Estudios Constitucionales, 1985, y GaRRORENA, A., Representación politica y consitución democrática. Madrid, Civitas, 1991, págs. 48/51. 
para que así como los de la Diputación antigua del Reino, que eran de igual número y circunstancias, repartían las contribuciones con igualdad a eclesiásticos y seculares, sin excluir las religiones, lo hiciesen también ellos por haberse derogado los fueros, que hablaban con el estado eclesiástico. Pero ni han hecho lo que el Rey quería, ni se les ha podido reducir a ello, fundándose siempre en dificultades ridículas, siendo la mayor que lo que la Diputación hacía era en virtud de las resoluciones del reino, cuya autoridad no residía en el rey, y con esto ha quedado su inspección reducida solamente a cobrar sus sueldos" ${ }^{82}$. $Y$ todo, la intención y pretensión de un diseño, quedaba definitivamente sellado algunos años después cuando a raiz de la implícita liquidación del Gran y General Consell del Regne de Mollorca - por el decreto del 28 de noviembre de 1715- los memoriales remitidos por el marqués de Casafuerte y la Audiencia muestren su incertidumbre sobre el destino de la Universitas: "no queda establecida providencia alguna para el universal del Reino, ni en quién ha de residir su representación, facultades y administración de caudales de la Universidad del Reino". La consulta del Consejo de Castilla que suscitan, y la Real Cedula que los responde, de 11 y 22 de julio de 1718 respectivamente, plasmaban entonces con rotundidad una modalidad de dominio político que pasaba por la ruptura y desarticulación de la representación compleja del regnum: "Obsérvese puntualmente lo que tengo mandado en el Decreto de Nueva Planta de Gobierno de Mallorca; y en su consecuencia resuelvo que no haya cuerpo que represente el reino, ni el grande y general Consejo que había antes" ${ }^{83}$.

Al retener la consideración y evaluación de la fidelidad en la esfera de esos cuerpos que representan al reino, en la Universitas que se hace visible por vía de sus tres brazos y cuenta con unas asambleas y órganos institucionalizados para la concurrencia de unas potestades, Robres retomaba los códigos fundamentales de una cultura constitucional cuyo discurso, de la mano del Conde de Frigiliana, se había hecho presente incluso en la propia reunión del gabinete en la que se dilucida el perfil de los decretos de nueva planta ${ }^{84}$. Desvaneciendo cualquier posible idea

82 Melctior de MACANAZ, Regalias, pág. 21.

83 Memoriales, consulta y real cedula en Archivo Histórico Nacional (AHN), Consejos, Ig. 6813/26. Cfr., también, Gay Escoda, Corregidor, págs. 127 y ss.

84 "Que aunque era la verdad que los naturales de Aragón, Valencia y Cataluña la mayor parte se consideraban inclinados al Archiduque, y que esto lo verificaba el sacrifico de sus bienes y vidas a sus servicio, con todo era cierto que Aragón, Valencia y Cataluña, representados por sus diputaciones y magistrados habían dado al rey con repetidos avisos pronta noticia de todas las importancias; que los diputados y ciudad de Barcelona en el año de 1704 y 1705 , cuando Barcelona 
de unanimidad acerca de la nueva planta de gobierno y significando la concurrencia de alternativas de muy variado signo que afectaban ya a la propia activación del modelo, las Memorias dejaban constancia al respecto, anudando en torno a Frigiliana y Francisco Ronquillo las dos irreconciliables líneas argumentales de definición política que abiertamente colisionan en el seno del gabinete: "se disputaba fuertemente en Madrid desde la victoria de Almansa, el abrogar o conservar nuestros fueros. Estaba partido el gabinete en fracciones: el Conde de Frigiliana, presidente de Aragón, del último parecer; el presidente de Castilla, Francisco Ronquillo, fomentaba el primero". Mayores precisiones sobre la identidad de los sujetos que soportan las distintas posiciones introducia el Marqués de San Felipe en sus Comentarios de las Guerras de España: "Se ventiló en el Consejo del Gabinete del Rey Católico la cuestión de si convenía quitar con decretos estos privilegios y fueros o, viniendo la ocasión, no observarlos, por no exasperar con esta real deliberación los ánimos de los catalanes, que se sacrificarian mil veces por sus fueros. De esta última opinión fueron el Duque de Medinasidonia, el de Montellano y el Conde de Frigiliana; pero prevaleció la contraria, seguida de Amelot, don Francisco Ronquillo, el duque de Veraguas y el de San Juan, y se formó y publicó el decreto con términos que quitaban toda esperanza al perdón" ${ }^{85}$. La suya, sin embargo, era una historia al servicio de un monarca, Felipe $\mathrm{V}$, dicho el animoso, propia de un artisan of glory y ajena por completo al registro de composición de unas Memorias. Al Conde de Robres le ocupaba fundamentalmente la fijación de los pilares discursivos sobre los que se dilucidaba el desencuentro para así consignar la postergación de una propuesta, la fijación de una planta "sin mudarse el gobierno, imponiendo en Cortes el tributo perpetuo", frente a la concepción simbolizada por Ronquillo, a su comprensión genérica del orden monárquico - «ser el univoco gobierno el más compatible con la monar-

había sido sitiada por el Príncipe Darmstadt y aiiados, los comunes de Cataluña habían puntualmente advertido al rey; que nadie ignoraba que las violencias habian ocasionado a mucho pueblo el tomar las armas; que aquella acción no era el comun del Principado, representado por sus diputados; que los valencianos en 1705 habian avisado al rey, instando socorro de tropas y ofreciendo pagarlas y que lo ejecutaron; que habían hecho presente al Rey io abierto e indefenso de aquel reino y lo que se necesitaba de socorro, y últimamente que previnieron al rey que el regimiento de Nebot que se destiriaba al socorro le consideraban de poca seguridad, dando a entender que no debia confiarse en él; que Aragón en 1706. desamparado todo el reino de las tropas, no tenia fuerza para oponerse; que avisaron a la reina con repetidos extraordinarios se les enviasen socorros, que no terían gente de guerra, que el país era todo abierto y no hallaban disposición para defenderse sin el abrigo de tropas". Cfr., CASTELLvi, Narraciones históricas, II, págs. 405/406.

85 BacallaR y SanNa, Comentarios, pág. 145. 
quía"- y el entendimiento de la communis utilitas que la informa en detrimento de unos ordenamientos privativos: "Que la diversidad de gobierno en las provincias súbditas a un mismo cetro suscita emulaciones entre los naturales incompatibles con la unión recíproca para concurrir sin desigualdad a las necesidades públicas, lo que cede en sumo detrimento del monarca" ${ }^{86}$.

Sólo entonces, desplegado con detalle el complejo y contradictorio paisaje intelectual del gabinete, y anotada de forma paralela la inquietante tendencia que conducía al monarca por los derroteros característicos del absolutismo patrimonial ${ }^{87}$, el relato de Robres podía aislar un principio, el de la capacidad monárquica de disposición de unos derechos por motivo de conquista, que Ronquillo daba por supuesto dentro de su marco dogmático al reconocer que «si el temor de perder sus privilegios, en vez de detener sus bríos, les había precipitado, era menester quitarles para siempre estos temores para asegurar su obediencia, y jamás podía ser de otro modo que revocándolos". Planteamiento bien preciso del ius que pudiera competir a la potestas del príncipe en relación con los iura de los territorios, su desarticulación significaba dinamitar el fundamento de la Nueva Planta. $Y$ en esa dirección profundizan las Memorias arrastrando todos los argumentos de autoridad sobre la estricta complementariedad entre Rex y Regnum que venian imprimiendo su genuina identidad al constitucionalismo aragonés ${ }^{88}$ : “Es contra nuestras leyes fundamentales, establecidas desde la fundación de nuestra Corona, el que los reyes puedan por sí solos establecer en ellas leyes y derogarlas; en toda ella es privativa tal autoridad del Rey y la Corte general juntamente, y estas leyes establecidas son recíprocos pactos con que igualmente se ligan soberanos $y$ vasallos, que por esto deben jurarlas sus Monarcas en la nueva sucesión, y hasta entonces no pueden ser compelidos los súbditos al homenaje y juramento de fidelidad: que aún en el caso de rebelarse el vasallo, no estaba en manos del Rey la derogación de las leyes, porque previniendo ellas

86 CONDE DE ROBRES, Guerras Civiles, págs. 365/367.

87 "Y el primer instrumento con que empezaron las diligencias jurídicas los comisarios fundaba el procedimiento en que el Rey, por la conquista que habian hecho sus armas de Aragón, era señor de todos los haberes de sus pobladores, aún de los eclesiásticos". CONDE DE ROBRES, Guerras Civiles, págs. 364/365.

38 Cfr., Gil PuJol, X., “Constitucionalismo aragonés y gobierno habsburgo: los cambiantes significados de libertad", en KAGAN y PARKER, España, Europa y el mundo atlántico, págs. 217/249; Fernández Albaladejo, P., "Lex Regia Aragonensium. Monarquía compuesta e identidad de reinos en el reinado de Felipe III», en MARíinez Ruiz, E. (coord..), España y Suecia en la época del Barroco. Madrid, Actas, 1998, págs. 51/72, y RuBiÉs, J.P., «Reason of State and Constitutional thought in the Crown of Aragon, 1580/1640". The Historical Journal, 3871 (1995), págs. 1/28. 
mismas castigo a este delito, quisieron así los legisladores que ni aun él las abrogase» 89 .

El Rey en Cortes. La suma de iurisdictiones que forman la iurisdictio superior del reino, asi colegiada. Las leyes fundamentales ${ }^{90}$. Unas leyes de entendimiento contractual que arraigan en el momento fundacional de la comunidad política, que impedian al monarca arrogarse una potestad legislativa exenta y limitaban al Rey en Cortes la facultad de disposición del ius propium. Ahí estaba cifrada, en el léxico de Robres, la clave del modelo y la ratio que invalidaba en toda su extensión el diseño de nueva planta de 1707. En la especificidad del modelo constitucional aragonés que las Memorias tan bien recitan y que así tanto las distancian del cuño dinástico que imprime su sello genuino en piezas como la Alegación jurídica de Alejandro de $\mathrm{He}$ rrera que tampoco dejan de definir unas leyes fundamentales - «aquellas que los pueblos con los Reyes hicieron para conservación de sus Reinos y Monarquías, como firmes y estables, a las cuales se obligan los mismos Príncipes sin que las puedan alterar»- y unas leyes federales de la monarquía - «pactos que como todos reconocen se llaman federales deduciéndose el nombre de la palabra foedus - pero que únicamente las convocan en la sustanciación del encuentro entre los derechos propios de unas Casas sobre la Corona, para levantar así acta sobre «la ley fundamental que hay en España de que los extraños no pueden suceder en la Corona, como consta de las leyes antiquísimas de los Godos" y para recordar "la ley federal exclusiva de los franceses a la sucesión de los Reinos de España " ${ }^{91}$. En la estela de la invocación de unas leyes fundamentales, y siempre con la nueva planta en el punto de mira, el acento de las Memorias recaía y se posaba por el contrario en la posición y prerrogativa ante todo de unas Cortes que comparten lógica constitucional con un parlamento inglés o una

89 CONDE DE ROBRES, Guerras Civiles, págs. 367, 369/370.

90 Para el concepto de ley fundamentai y la limitación de la majestas que puede significar, cfr., OESTREICH, G., "From contractual monarchy to constitutionalism», Neostoicism and the early modern state. Cambridge U.P., 1982, págs. 166/ 186 , y también, para la renovada vitalidad que con las primeras luces del Setecientos y en ciertos ámbitos europeos imprime el debate sobre la tolerancia confesional en el desarrollo y maduración de la cuestión, cfr., LOMONACO, F., Tolleranza e libertà di coscienza. Filosofia, diritto e storia tra Leida e Napoli nel secolo xvII. Nápoles, Liguori Editore, 1999.

${ }_{91}$ ALEJANDRo de HeFrerra, Alegación jurídica, págs. 32/33, 95 y 1157118. Para la posterior invocación de esas leyes fundamentales y federales de la monarquía por parte de unas Cortes catalanas inmersas a la altura de 1706 en la acuñación e incorporación de una normativa de regulación sucesoria de la dignidad real como ley a su vez fundamental de la constitución acumulativa del Principado, cfr., Casteilvi, Narraciones históricas, II, pág. 259: Constitución o ley de exclusión de la real estirpe de los Borobones al Condado de Barcelona hecha por el Rey Carlos III, propuesta y aprobada por los cataianes en las Cortes Generales y publicada el 31 de marzo de 1706. 
dieta imperial pero que no guardan semejanza alguna con unas Cortes castellanas: «Porque no es en Castilla como era en Aragón, y es en Inglaterra, y es en el Imperio y otras coronas, donde como aunque las resoluciones de las Cortes, dietas o parlamentos no tengan fuerza de ley sin la aprobación del soberano, pero no puede tampoco el soberano establecerla sin el consentimiento de estas asambleas, que es preciso que las convoque a ese efecto. Pero en Castilla sus Cortes sólo tienen el derecho de suplicar lo más conveniente, y el rey le tiene con plena soberania, no sólo para consentir o no en las súplicas, sino también para no habiéndolas admitido, disgregadas ya las Cortes, promulgar leyes conforme a ellas, lo que puede hacer sin la solemnidad de juntar los estados del reino" ${ }^{92}$.

Ese era el mensaje que más interés se tenía en transmitir, el componente más decididamente contractual de toda la exposición: el equilibrio y armonía de los poderes del rey y del reino concebidos como elementos compositivos de un orden al que se debian. Toda una concepción, en suma, del poder real, con su correlativa demarcación entre un dominio político y un dominio despótico, que venía a sustanciar el reverso argumental del discurso armado por Antonio lbáñez de la Riva o Melchor de Macanaz en el contexto de la guerra civil cuestionando abiertamente la jurisdicción de la república del reino aragonés. La figuración confesional del conflicto, "esta guerra que nos hacen los infieles es guerra de religión", no impide entonces a lbáñez de la Riva cargar las tintas sobre la potestas del monarca, sobre su iurisdictio, que entiende sometida a un género de restricciones, las impuestas por la vigencia de unas jurisdicciones privativas y unos ordenamientos particulares, que la desnaturalizan hasta convertirla en un atributo puramente nominal: «En Aragón tiene el rey poco más que el nombre". Si entre fueros y costumbres, jurisdicciones particulares y potestades legislativas territoriales, un antiguo presidente del Consejo de Castilla y en la fecha arzobispo de Zaragoza descubría y describía el mismo campo minado para la soberanía que Macanaz plantea a Amelot en su memoria de mayo de $1707^{93}$, las Memorias del Conde de Robres así interponían, sin más, una verdadera enmienda a la totalidad. Amparadas y apegadas además en todo momento al motivo de estructura constitucional que más censura Melchor de Macanaz — «estas Cortes se habian tomado más autoridad que la que tiene el Parlamento de Inglaterras ${ }^{94}-y$ al que ya

92 CONDE DE ROBRES, Guerras civiles, pág. 17.

93 Cfr., Carta de Antonio Ibáñez de la Riva al Marqués de Mejorada del 28 de julio de 1706. (BN. Mss., 5.805) y para la Memoria de Macanaz, AAE. CP (E), vol. 168, fol. 68.

34 Melchor de MAcanaz, Regalias, pág. 118. 
previamente, desde el Crisol de le española lealtad de Tomás de Puga y Rojas, se le venía imputando una responsabilidad capital en la animación de la contienda civil: «aquellos que con injustos fueros sólo han servido a la española Monarquía de vana ostentación de sus dominios, blasonándose más de repúblicas libres que de tributados vasallos» ${ }^{95}$.

Desde esa comprensión compuesta de la nación, y su representación, las Memorias transitaban además sin dificultad y con naturalidad hacia un preciso entendimiento del derecho territorial que la fundamentaba y la combativa declaración de estricta indisponibilidad de sus formas de relación contractual con la cabecera monárquica que desde el momento bajomedieval habia venido jugando en Aragón el papel de auténtico topos constitucional. Incluyendo también una puntual precisión sobre la indefectible vinculación de la potestas del príncipe -que no resulta absoluta sino en Cortes- con la específica forma de adquisición del imperium. Y sin concesión alguna para quienes postulaban la posibilidad de que la rebelión invalidase las severas restricciones con las que una cultura tradicionalmente concibe la absolutio legis del príncipe, desde el momento que se reconoce como una posibilidad que no deja de estar contemplada dentro del mismo paradigma y catecismo constitucional, desarrollo por tanto que cabía encauzar dentro de su cuadro dogmático. Robres, de este modo, escribia de monarchia con las nociones de government by constitution en su empeño por desarmar la política de nueva planta. Proporcionaba y promocionaba, en definitiva, concepciones constitucionales de cosecha propiamente aragonesa y cuño libertario como herramientas de deslegitimación de los principios que soportan y encuadran el par de decretos de 1707.

Eran estos planteamientos todos bien sedimentados en el imaginario político aragonés cuyo predicado y canon constitucional testimonia una literatura que a la altura de 1676 encontraba puntual recapitulación bajo forma de Discurso histórico-fora!, jurídico-político ${ }^{96}$. Figurados como Nomophilaces, guardianes de las leyes, conforme a una tradición libertaria ampliamente difundida por Europa, los diputados del Reino entonces se servian del Discurso para significar a Carlos II una pauta y un canon cons-

95 Tomás DE PUGA y ROJAS, Crisol de la española leaitad, por la religión, por el rey, por la ley y por la patria. Granada, 1707, pág. 21.

96 Discurso Histórico-Foral, Juridico-Político, en orden al juramento que los Supremos y soberanos Señores Reyes de Aragón deben prestar en el nuevo ingreso de su gobierno y antes de que puedan usar de alguna jurisdicción. Zaragoza, Herederos de Diego Dormer, 1676. Para su contexto, cfr., BotelLA, E., Monarquia de España: discurso teológico (1590/1685). Tesis Doctoral, Madrid, UAM, 2002, cap. IV. 
titucional: «que en el entretanto que no juran los Señores Reyes al principio de sus reinados los fueros, no pueden ejercer alguna jurisdicción». El texto tenía ciertamente su contexto ${ }^{97}$. Le ocupaba una cuestión puntual: negar legitimidad y legalidad al nombramiento del virrey cursado por el monarca sin haber procedido previamente al juramento de los fueros. Esa era su intención: "se suspenda el ejercicio del Virrey hasta que fueses servido su Majestad de prestar la real jura». La interposición de la letra del fuero frente al despliegue de la potestad real propiciaba sin embargo una pormenorizada reflexión sobre el orden político de Aragón que trascendía los límites propios de la materia en cuestión para configurarse como un auténtico catecismo constitucional. Sin necesidad además de realizar ningún alarde de originalidad, una oportuna lectura de los clásicos, los de una cultura propia, los Zurita, Morlanes, Blancas, Ramírez o Briz Martínez, ya proporcionaba a los diputados el principal tejido argumental. El Discurso, al fin y al cabo, se concebía como un consecuente ejercicio de responsabilidad constitucional: "es el más principal cuidado de la Diputación la defensa de los fueros, costumbres, usos, privilegios y libertades del Reino" ${ }^{98}$. No procuraba por tanto abrir nuevas vías sino recitar una comprensión de la constitución de libertades ya notablemente consolidada. $Y$ ese era su merito. La tan aséptica como brillante costura de planteamientos aquilatados desde finales del Cuatrocientos por los tratadistas más selectos que conforman la matriz de autoridades del constitucionalismo aragonés ${ }^{99}$.

Concebido así como un recorrido por las principales cotas literarias de la orografía constitucional aragonesa, el axioma que soporta el Discurso fijaba ya de entrada la cuestión en términos que posibilitan luego el enunciado de la idea libertaria de monarquía nomística: "en Aragón primero fueron las leyes que los reyes". Ese era el principio y esa era la clave: "antes de pasar a elegir Rey, quisieron los nuestros hacer leyes con que después los gobernaran, y así hicieron las que llamaron Fueros de Sobrarbe". En Sobrarbe comenzaba el Discurso pues en Sobrarbe entendían unos diputados que se constituía el reino de Aragón. Y lo hacían sin ambigüedad ni indecisión. Anticipando que el protagonismo del texto recaía no tanto en la ley como en los fueros y consignado la intervención decisiva del cuerpo político en el momento fundacional: «las leyes que llamamos Fueros de Sobrarbe las pudo hacer el pueblo aragonés congregado en

\footnotetext{
97 Álvarez Osopio, A., «Fueros, cortes y clientelas: el mito de Sobrarbe, Juan José de Austria y el reino paccionado de Aragón (1669-1678)", Pedralbes, 12 (1992), págs. 239/291.

98 Discurso, pág. 118.

99 Cfr., Gil Pujol, Constitucionalismo aragonés, y Fernández Albaladejo, Lex Regia.
} 
estado de libertad....formando una República distinta y separada, y un Cuerpo místico y político en el cual estuvo la facultad legislativa para establecer dichos fueros que llamamos de Sobrarbe". A continuación se introducía el entendimiento de esos fueros como Ley Regia y unas significativas precisiones sobre la restrictiva modalidad de traslatio imperii que determinan el perfil de la suprema potestad: “la Ley Regia y suma potestad que se traslado del pueblo aragonés en los señores Reyes se ha de medir y nivelar con los pactos y condiciones con que se transfirió dicha potestad». $Y$ de inmediato, sobre esa figuración y equiparación del primer momento político del reino con la lex regia, e incidiendo nuevamente en los pormenores de la traslatio y la definición ajustada del pactum, se alcanzaba el nudo del Discurso: la vía política de comprensión de la república del reino. Una concepción constitucional propiamente política, entendida como mediación y comunicación reglada entre el príncipe y los estamentos, fundada en la presencia cívica y sustancia política del reino que consagra la propia modalidad constitutiva de la comunidad: «entre los pactos y leyes de Sobrarbe, uno de ellos, y de los más principales, era que por la traslación que el Pueblo hacia en su Majestad no se abdicase del Reino la facultad legislativa, sino que aquella quedase asi en el Reino como en su Majestad. De ahí es que los Señores Reyes en Aragón no tienen por sí, a solas, poder legislativo, sino que lo tienen juntamente con el Reino, de calidad que para el establecimiento de cualquier ley se requiere el consentimiento y aprobación del Reino, y esto no sólo con voto consultivo sino decisivo". El mensaje era evidente: el poder del rey no podía concebirse fuera del poder del reino. Y así se hacía explícito: «la absoluta potestad en Aragón no se halla en su Majestad, sino tan solamente en la Corte General, donde concurre el Rey y el Reino, en quienes así unidos reside la facultad legislativa, de calidad que en algún modo su Majestad con la Corte General es superior a si mismo solo, por cuanto sólo no puede revocar las leyes hechas, y con la Corte tiene el absoluto poder de hacerlas y revocarlas, y porque con la Corte General, como legislador, no esta sujeto a dichas leyes, y sin la Corte General está obligado a su observancia, como súbdito en alguna manera de si mismo» ${ }^{100 .}$

La Corona, según recitaba el Discurso, ejercía en Aragón su suprema jurisdicción sobre la comunidad política en Cortes, como Rey en Asam-

100 Discurso, págs. 21, 27/30. Y cfr., para sus precisos argumentos, Lomonaco, F., Lex regia. Diritto, filología e fides historica nella cultura político-folosofica dell clanda di fne Seicento. Nápoles, Guida, 1990, y Höpf, H. y Thompson, M., "The History of Contract as a Motif in Political Thought", American Historical Review, 84 (1979), págs. 919/944. 
blea, sede en la que residía la potestad más absoluta por sustanciarse en ella la unión de la cabeza y el cuerpo. No cabía, por tanto, reducción de Aragón a un mínimo común denominador con las formulas de composición política de otros territorios de la monarquía: «así como fue singular en sus principios también lo ha sido y lo es en su conservación". Rememorar las convenciones que venían regulando un género de gobierno requería entonces dejar reiterada constancia de unas especificidades territoriales de signo propiamente políticc - «es Reino tan singular que aún en lo político se diferencia de todos"- - y otras más trascendentes de cuño juridico, con oportuna afirmación de un derecho común aragonés - «los Fueros son el Derecho Común de los aragoneses" - y correlativo extrañamiento de un derecho común y leyes de Castilla ${ }^{101}$. Cabía incluso, interesando a los diputados antes que la distribución formal de prerrogativas la fijación del origen y la naturaleza legal del reino, un sugerente excurso por la escolástica castellana ${ }^{102}$. En una controlada operación de incorporación -e impostación al servicio de una filosofía política sustancialmente divergente- de ciertos materiales pertenecientes a un tronco discursivo y a una cultura política de matriz teológica, el De Legibus de Francisco Suarez se instrumentalizaba aquí para apuntalar la concepción contractualista del modelo ${ }^{103}$. Los tratados de Luis de Molina se invocaban luego para sellar una comprensión de la monarquía como mayorazgo, que devenía ahora en garantía de la estructura legal del reino ${ }^{104}$. Y finalmente Covarrubias y

to Discurso, págs. 49 y ss., $62 / 63$ y 114

102 Para la filosofía política escolástica, cfr., Ferraro, D., Ferraro, Itinerari del volontarismo. Milán, Franco Angeli, 1995, passim, y BRETT, A.S., Liberty, Right and Nature. Individual rights in later scholastic thought. Cambridge U.P., 1998, págs. 123/204, lecturas ambas que ilustran la insalvable distancia entre el teologizado modelo constitucional escolástico y la comprensión libertaria articulada por el Discurso y clarifican así la intención que rige la operación de textualita acometida por los diputados aragoneses.

${ }_{103}$ Discurso, pág. 28: "Se supone también, por indubitable, que en las Monarquías del mundo, los Supremos Señores Reyes no tienen otra, ni más potestad política ni superior, que aquella que voluntariamente quiso el pueblo concederles, la cual es mayor o menor conforme la diversidad de las Naciones y Pueblos que quisieron espontáneamente dar más o menos potestad a sus Reyes, de calidad que si los Señores excediesen de aquella facultad concedida en el principio y origen de su reinado, sería violento e injusto el imperio y mando que ejerciesen". Sobre el viraje en la concepción pactista que implica la mirada a la escolástica castellana, cfr., Fernandez ALbaLADEJo, Lex Reia, y LALINDE, J., "El pactismo de los Reinos de Aragón y Valencia", El pactismo en la Historia de España. Madrid, Instituto España, 1980, págs. 115/139. Para la posición crucial del pacto en la figuración de la constitución política catalana, cfr., FERro, V., El Dret Públic Català. Les Institutions a Catalunya fins al Decret de Nova Planta. Vic, Eumo, 1987, págs. 30 y ss.

104 Discurso, págs. 32/33: «Todos aquellos fueros, solemnidades y requisitos que se tuvieron entonces presentes, para la eleccióri del primer Rey, se deben repetir en todos sus sucesores, aunque después la Corona no se difiera por elecciórı sino por sucesión, como en nuestro Reino. For cuanto todos los Señores Reyes, aunque sucedan por derecho de sangre no reciben la Co- 
Vázquez, sus textos, servían para fundamentar un procedimiento gubernativo basado en el consenso, en la constante interacción de los miembros de un cuerpo político constituido por el rey y el reino ${ }^{105}$. La visita, que resulta manipulación del componente genético de unos lenguajes y unos tejidos conceptuales, rendía así sus frutos. La tan efectiva instalación como descontextualizada incorporación de ciertos argumentos de los tratadistas escolásticos castellanos en las coordenadas de un discurso foral aragonés se empleaba para clausurar una concepción patrimonial y así denegar al soberano cualquier facultad de disposición sobre el derecho, sobre las "leyes, que son origen y principio de este Reino". Para afirmar, en definitiva, que el reino, el derecho que lo constituye, no era cosa de la que el Rey pudiera libremente disponer: "Su Majestad, no teniendo, como no tiene, la facultad legislativa y absoluto poder, sino que reside en Cortes, no podrá derogar sin ella ningún Fuero ni ley paccionada, ni dispensar sus disposiciones aunque haya justa causa, porque todo esto está dispensado a quien tiene la facultad legislativa" ${ }^{106}$.

Más lejos del puzzle constitucional diseñado por una neoescolástica castellana no podía por tanto ubicarse un Discurso que sin embargo, y en beneficio propio, no dudaba en visitar a sus autoridades. En la medida que en el teologizado cuadro neoescolástico el orden social se entendía concebido por el designio divino ya antes de su formal consagración por parte de los hombres, predeterminado entonces por la ley natural, la legitimación conferida al poder del príncipe precedía, lógica e históricamente, incluso al propio momento de su encarnación institucional, al primer tiempo político del reino, al pacto fundacional y constituyente de la comunidad política. La misma terminología contractual profundizaba en esa línea, y procedía a la especificación de una potestas que, independientemente de

rona Real del último poseedor, sino del mismo Reino, que fue el que traspasó legítimamente su poder debajo de dichos pactos y fueros...Y así se ha de suponer repetidos en todos los sucesores, y que todos están obligados a su cumplimiento, a ejemplo de los sucesores de los Mayorazgos, que siempre se suceden al primer instituyente y no al último poseedor, y por consiguiente en los cargos y obligaciones que el primero impuso. Y así, siendo la sucesión de la Casa Real el mejor Mayorazgo, siempre tendrá el último poseedor obligación de cumplir con los cargos, pactos y condiciones que en el principio de su formacićn se tuvieron por presentes". Para la institución, y la suerte que corre el cuerpo politico estamental en Castilla tras la configuración de la Corona como mayorazgo, cfr., por todos, CLAVERO, B., Mayorazgo. Madrid, Siglo XXI, 1989.

${ }_{105}$ Discurso, págs. 31/32. Para el entendimiento del principio y la figuración sobre el mismo de un género de gobierno, con mención de Covarrubias, crr., Dusso, G., "Una prima esposizione del pensiero politico de Althussius: la dotrina del patto e la costruzione del regno", Quaderni Fiorentini, XXV (1996), págs. 65/125.

105 Discurso, pág. 31 
su gestación, escapaba en su determinación más profunda a los propios integrantes de la comunidad: «supuesto el traspaso de este poder a la persona del rey, ya éste hace las veces de Dios, y el derecho natural obliga a obedecerle, de la misma manera que cuando una persona particular se vende y entrega a otro como esclavo, esa propiedad tiene su origen sencillamente en los hombres, pero, supuesto el contrato, el siervo por el derecho divino y por el humano está obligado a obedecer a su señor» ${ }^{107}$. Deslindar Aragón de esa tradición y comprensión constitucional era precisamente lo que ocupaba al Discurso. No se trataba de declarar un combate o de presentar una enmienda a la totalidad, ni mucho menos. Se procuraba dejar sentado ante el monarca una visión cerrada e intocable de la historia del reino que lo ubicaba constitucionalmente en las antípodas de ese panorama. De retratar pues un universo de fueros y libertades que se extiende sin dejar ningún resquicio para la afirmación de una voluntad soberana revestida de autoridad sobre el derecho: "ha quedado en Aragón por máxima irrefragable que por ninguna consideración de utilidad, conveniencia pública o privada, ni por bien de la justicia puede el monarca violar los fueros". De ilustrar, dando un paso más, que las cavilaciones filosóficas, teológicas o políticas no tenían cabida en un territorio en el que, desde Sobrarbe, "el reino dispuso de la Corona como patrimonio suyo". Y sobre todo se trataba de hacerlo para situar en sus justos términos el juramento, la materia al fin y al cabo que suscitaba la composición del Discurso en el contexto del debate de 1676: "la religiosa observancia del juramento pareció el úrico medio para tener a los Señores Reyes obligados con mayor vínculo al cumplimiento de las leyes paccionadas en la entrega de un Reino libre» ${ }^{108}$.

Instalado culturalmente en la contemplación y comprensión de un reino libre, fundado y fundamentado sobre unas leyes que son fueros, el Conde de Robres procesaba su demolición bajo forma de Memorias. Comprometido con sus códigos cardinales, «el ser Rey es contrato", que diría Francisco Gilabert ${ }^{109}$, de lo que se ocupaba era de dinamitar - para la historia- la legalidad y legitimidad de la operación, de negar en lengua y cultura constitucional aragonesa la ratio de la nueva planta. Repudiando

107 Francisco SuÁrez, De Legibus ac Deo Legislatore. Lisboa, Gómez de Loureyro, 1612, lib. III, cap. iv, n. 6.

108 Discurso, págs. 32 y 35.

109 Francesc GILABERT, Discurso sobre las obligaciones que los que representan el corazón de Cataluña tienen, Barcelona, 1616, fo!. 11v. ${ }^{\circ}$, y cfr., RuBIES, J.P., "Don Francisco de Gilabert i la idea de govern mixt: fortuna i prudencia del constitucionalisme cátala dels segles XVi i XVII", Pedralbes, 16 (1996), págs. 97/132. 
categóricamente, dentro de esa misma lógica, incluso la línea de relativa rectificación apuntada en el segundo decreto que acomete el desahucio de la planta antigua, el del 29 de julio, "que permitía recurrir a la clemencia del rey para confirmar los privilegios en todo lo que no se opusiese a las leyes de Castilla», desde el momento que "no fundadas estas mercedes en las leyes patrias no tienen más subsistencia que la voluntad que les concede» ${ }^{110}$. El círculo del rechazo constitucionalmente fundado así se cerraba en las Memorias. Arrojando toda una comprensión y cultura constitucional sobre el tapete. Reivindicando, si se quiere, una cumplida concepción en términos de monarquía mixta. El comentario de texto no era sin embargo, y como anticipaba ya su autor, el único trabajo que se imponia en la redacción de unas Memorias. La interiorización del episodio pasaba también por un sondeo del contexto, no precisamente material sino propiamente cultural, encaminado a descubrir la intención que subyace en la gestación de un espacio político hispano uniforme. $Y$ ese anillo, el de la identidad genética de la propia operación y su manipulación de unos ordenamientos territoriales propios, de unos derechos particulares, tampoco parecía suscitar ninguna duda al Conde de Robres. El «oráculo de París» había emitido dictamen. Era la política de la nueva dinastía ${ }^{111}$. Pero la impronta del decreto, la cultura política en la que arraigaba, se decía propia y genuinamente castellana: «llegaba el tiempo tan deseado del CondeDuque de Olivares, de que los Reyes de España fuesen independientes de toda otra ley que de la de su natural piedad, en que principalmente consistía el gobierno monárquico" ${ }^{112}$. Incorporando así una personal lec-

110 Conde de Robres, Guerras Civiles, pág. 369.

111 CONDE DE RoBres, Guerras Civiles, pág. 367. Cfr., también, en esa misma línea, Crisol de fidelidad, pág. 7 («todo el gobierno político y militar dependía absolutamente de las resoluciones del Real Gabinete de Versalles") y, en el polo opuesto, los elocuentes alardes de Jean ROUSSET DE Missy en su Histoire publique et secrete de la de la Cour de Madrid dès l'avenement du Roi Philippe $V$ à la Couronne avec des considerations sur l'etat présent de la Monarchie Espagnole (CoIonia, Pierre le Sincere, 1719, pág. 74): “Outre cela I'Ambassadeur de France étoit seúl le Conseil du Roi, \& gouvernoit avec lui \& celui qu'on nomme en Espagne le Secretaire des Dépesches Universelles. Ces deux personnes décidoient absolutement de tout sorte d'affaires, sans en comuniquer aucune aux Grands de la Natior, Espagnole".

112 Cfr., CONDE DE Robres, Guerras civiles, pág. 367 y CASTellvi, Narraciones históricas, II, 404/05, para la liamada en causa de la figura del Conde-Duque de Olivares también por parte de Frigiliana en la reunión del Gabinete que debate la liquidación del ordenamiento foral aragonés. Cfr., igualmente el Crisol de fidelidad (pág. 8) y la Lealtad catalana (pág. 24) para el aforismo en el que se encierra el espíritu de la nueva planta ("un rey, una ley y una moneda") y que ya en el momento de 1640 había servido a autores como Martí Viladamor en su empeño de capturar y retratar el designio político de Olivares (Noticia Universal de Cataluña, en X. Torres (edt.), Escrits politics del segle Xvil, I, Vic, Eumo, 1995, pág. 86). Frente a ello, y para fijar con más propiedad los sinuosos meandros en los que la gabeta del Conde de Robres naufraga, cfr., Marqués de Santa Cruz de Mercenado, Rap- 
tura del orden constitucional castellano, figurando un espacio político donde "sólo la voluntad del monarca era la ley», lo que Robres procuraba y pretendía era proceder a la fijación de una secuencia histórica en la que el sentido del decreto adquiriese su verdadera dimensión y significado: "en varias ocasiones habían procurado en Castilla la extinción de las leyes de la Corona de Aragón, pero nunca más declaradamente que en la era del señor Felipe IV y ministerio del Conde-Duque de Olivares. De ahí resultaron las conmociones de Cataluña, donde se creyó en Aragón que se habian disputado sus Fueros, y como aunque la piedad de los Reyes asegurase los ánimos, se translucía más y más la mala disposición de la nación dominante hacia ese asunto". La posición y pretensión dominante de una nación dentro del tejido regnícola de la monarquía, que Robres imputaba a la unión y ajuste de 1478 , emergía como perno argumental y veta de reconstrucción de la historia política de la monarquía hispana. Se incorporaba así una clave de lectura del pasado constitucional monárquico que permitía, ante todo, marcar distancias, fijar contrapuntos y predicar primeramente que uno de sus territorios, el aragonés, y desde la unión de coronas que marca la salida bajomedieval, «fundó su felicidad en la conservación y aumento de sus libertades comunes» ${ }^{113}$.

sodia económico, política, monárquica. Madrid, Antonio Marín, 1732 (que cito por la edición de la Universidad de Oviedo de 1984 con estudio preliminar de Alvaro Galmés de Fuentes), pág. 31 - «De esta igualdad de moneda, pesos, medidas y lenguaje resultaría mayor unión en los Nacionales y facilidad en las correspondencias, contratos, cambios y facturas, todo lo cual explana el camino del comercio - y especialmente el Discours préliminaire de Maudave, en el que se recogen las líneas de fuerza con las que opera toda una literatura desde la comparecencia de los Comentarios de Bacallar y Sanna y cuyo símbolo es el citado Genio de los Catalanés: «Depuis la reunión des Courónnes de castille et d'Aragon, qui fut la suite du mariage de Ferdinand et d'Isabelle, l'Espagne plus puissante et plus considéree au dehors a toujours été agitée au dedans. Cette agitation s'est fait sentir par intervales et avec force sous les Rois Autrichiens: elle éclata pendant le Ministere du Comte-Duc d'Olivares: ce qui contribua à encourager les Portugais dans le dessein de se séparer du corps de cette vaste Monarchie et de reproduire sus le theatre du monde un état mediocre par son indepéndanse et que ses richeses, son comerse et sa situation rendent respectable. Le testament de Charles II excita l'esprit remuant des Catalans et des Arragonais, en leur annonçant qu'ils ne seroient plus governés par une Maison contre laquelle on les avoit vûs s'armer. Les Princes Autrichiens leur devinrent chers en cessant d'etre leurs souverains. Ils songerent dés lors à maintenir le sceptre dans des mains don't ils avoient voulu l'arracher. Le corps entiere de l'etat reçutpourtant avec respect le nouveau Maitre que le testament du dernier Roi lui donnait: mais I'Arragon et la Catalogne se preparent en secret a conserver une domination qui leur plaisoit d'autant plus, qu'elle faisoit nâitre l'occasion de deployer cet esprit inquiet et volage que les castillans leur reprochent, et que leur histoire entiere prouve invinciblement. Telle est la bizarrie de l'esprit des hommes, que la haine qui divise ces deux peuples fut, peut-être, le plus puissant motif qui determina les Castillans à rester inébrantables dans le ferment fait à leur Roi" (MAUdAVE, Memoires, págs. XIII/XV).

113 Cfr., CONDE de RoBres, Guerras Civiles, págs. 367 y 27/28 respectivamente, y Castellvi, Narraciones históricas, I, pág. 59, donde se irisiste también en la problemática «posición preeminente de Castilla" que se establece y consagra desde la época de los Reyes Católicos. 
En la memoria de nación, en la memoria de naciones, era donde las Memorias fijaban un intencionado contexto de lectura para el par de decretos del verano de 1707 que liquidaban la tradicional identidad agregativa de la monarquía. Por sabido, y bien sabido, Robres no dejaba entonces de ilustrar la compleja cartografía constitucional de Hispana. Ese horizonte, el de una cultura jurídica hispana, y así la imagen de una Hispania que como tal desconoce un ordenamiento común de naturaleza territorial y resulta jurídicamente constituida por una constelación de derechos territoriales, convenía a su discurso. Servía fundamentalmente como anclaje para su pretensión de desvelar unos antiguos propósitos políticos de dominio castellano que encontraban ahora tiempos favorables al desdoblarse una guerra europea por la sucesión de la corona hispana en un conflicto entre territorios con sus respectivos derechos de por medio. Trascendiendo la esfera de los Sacra Themidis Hispaniae Arcana que desde Hannover y en 1703 Gerardo Ernesto de Frankenau procuraba revelar a Europa, y que para Robres resultaban ser tan sagrados como poco misteriosos, en sus Memorias le interesaba dejar constancia de una ya tradicional aspiración castellana preocupada por afirmar su derecho, no como uno hispano más, sino como el hispano sin más; es decir, desvelar el misterio que ahora, en 1707 , convertía a Frankenau, a su «explicación del origen y estado del derecho hispano", en testimonio no tanto de un presente como de un pasado ${ }^{114}$. Difuminadas las identidades regnícolas por la abolición de unos derechos territoriales y la pretendida superposición de un derecho común sobre base castellana, lo que Robres venía a activar eran las alarmas sobre los cegadores efectos que pudiera tener la adscripción desnuda del proceso de nivelación a la nueva dinastía, a su política, prescindiéndose de otras consideraciones, tan propiamente hispanas como decididamente castellanas. Figurar entonces la propia resolución del debate sucesorio de 1700 como dictado castellano, y tamizado por una razón histórica, tenía un sentido evidente y una pretensión manifiesta de vinculación con el espíritu que anima la nueva planta de gobierno de la Corona de Aragón: "no fue extraño el que todos los aragoneses juzgasen poco seguras sus exenciones bajo el cetro de un Monarca criado en una Corte sumamente absoluta y gobernado de dos naciones malhumoradas con ellas, tanto más cuanto en la serie de negociados

114 Gerardo Ernesto de FrankENau, Sagrados misterios de la justicia hispana, Hannover, 1703 (que manejo por la edición bilingüe preparacia por M.A. Durán Ramas, Madrid, Centro de Estudios Constitucionales, 1993), pág. 35. Y cfr., el estudio preliminar de Bartolomé Clavero a la edición de Durán Ramas de los Sagrados Misterios y los comentarios de Vallejo, De sagrado arcano a constitución esencial, págs. 433 y ss. 
de tan gran caso, y con la última resolución del sucesor, sólo los castellanos tuvieron parte» ${ }^{115}$.

La clave del proceso de concepción de la nueva planta constitucional hispana se detectaba en la compleja escena de la encrucijada sucesoria y, dando un paso más, en el monopolio que una nación se arroga en la sustanciación del expediente: "así como menos conformes los genios de los castellanos y aragoneses, era preciso que la inclinación absoluta de los primeros al señor Felipe $\mathrm{V}$, antes de morir el señor Carlos II, y su única intervención en las consultas y resolución del testamento, produjesen en los aragoneses aversión a un Príncipe que miraban como hechura de una nación que quería en tan gran caso tratarlos como súbditos". La tradicional aspiración de la cabecera monárquica hispana, interesada en la desnaturalización de unos ordenamientos jurídicos privativos, no era la que abiertamente conducía a la igualación de 1707: "siendo, como es constante, el deseo de los reyes antecesores de reducir todos sus dominios a una ley, es cierto que ninguno de ellos lo practico, pudiendo hacerlo". La ruptura también se entendía en esa dimensión. La liquidación de la comprensión agregativa que tradicionalmente venía identificando a una monarquía encerraba una reformulación del propio entendimiento de la prerrogativa real y así una relegación del idioma constitucional que la cimentaba. No sólo se trataba por tanto de negar la legitimidad y la legalidad de unos decretos sino de subrayar la ruptura del consenso que sobre la comprensión de aquella prerrogativa real habia regido en la cultura hispana incluso en situaciones excepcionales. El episodio de Antonio Pérez, en tiempo de Felipe II, y los sucesos de 1640 bajo Felipe IV, se incorporan expresamente en su relato para cerrar esa línea de derivación, consignándose que «ni uno ni otro de estos prudentísimos monarcas españoles inmutaron cosa alguna en las libertades de esas provincias" ${ }^{116}$. Con independencia de motivaciones profundas y torsiones argumentales, significar el compromiso pretérito de la cabecera monárquica hispana con los derechos y las libertades territoriales, y contraponerlo con un tiempo presente de disposición y suspensión por parte de la corona de esos iura propia y esas liberatates regni, introducía un sugerente registro de interiorización del proceso por el cual el diseño de la nueva planta quedaba vinculado a una recalificación, primera y anterior, operada al hilo del debate sucesorio en la comprensión de la propia Monarchia y en la concepción de la potestas del sobera-

CONDE DE Robres, Guerras civiles, pág. 28.

1:6 Conde DE Robres, Guerras Civiles, págs. 28/29 y 373. 
no. Lejos entonces de apuntar una lectura unidireccional del proceso, e interiorizarlo exclusivamente en clave dinástica, el protagonismo en la concepción del giro se reconocía a una Casa, la de Borbón, pero también a una nación, Castilla. La decidida fusión e imposición en 1700 de un núcleo de inquietudes e intereses compartidos por una dinastía y una nación, con la consiguiente postergación de planteamientos de otros sujetos territoriales, se apuntaba en el relato de Robres como la cifra que rendía cuenta de la discontinuidad con una concepción y concepción tradicional de la instancia monárquica y la summa potestas cuyas eversivas implicaciones para la ancient constitution aragonesa resultaban evidentes desde 1707.

Manteniendo la costumbre y estructura de todos y cada uno de los anillos concéntricos que conforman el tejido argumental de las Memorias, Robres por supuesto instalaba su planteamiento de la cuestión sucesoria en un horizonte histórico que le permitía una presentación más ajustada de los actores y una disección más pormenorizada de su intervención en la escena de 1700. Abría nuevamente su memoria hacia una historia de recurrentes desencuentros entre unas naciones, Aragón y Castilla, cuyos capítulos iniciales habían de situarse en el tiempo de la unión dinástica que sella la salida bajomedieval: "no pudiendo sufrir los castellanos las exenciones fundamentales de los aragoneses, ni los aragoneses el predominio con que quedaban sobre ellos los castellanos" 117 . Una trama histórica cuyos episodios centrales pasaban por la disparidad con la que además territorialmente se procesaba el conflicto con Francia que había marcado el devenir hispano altomoderno - «siendo natural el odio de Aragón y Francia, y accidental solamente el de Francia y Castilla» ${ }^{118}$ - y cuyo

117 Cfr., CONDE DE Robres, Guerras civiles, pág. 27, Crisol de fidelidad, págs. 8/9, Lealtad catalana, págs. 5 y ss, y el elocuente Fúnebre ocaso y oriente glorioso de nuestro amado sol, a distintos aspectos de la luna de octubre. Oración fúnebre que en las reales exequias de nuestro grande esclarecido monarca Carlos Segundo dijo el Padre lector Fray Mariano Anglasell y de Cortada. Barcelona, Rafael Figueró, 1700 (BC F.Bon., 777).

118 “porque aunque todos los españoles universalmente eran enemigos de los franceses, y en consecuencia de ello previnieron las renunciaciones de sus infantas Reinas Cristianísimas, por el horror de la posibilidad del dominio francés, con todo no era igual en todos la aversión. Los castellanos, separados de los aragoneses, unieron estrechísima hereditaria liga con la Francia, con cuyos socorros arrojó del trono a su hermano el rey d. Pedro, el señor Enrique II. Los señores Reyes de Aragón apenas expelieron los moros de su Corona, mantuvieron perpetuas guerras con la Corona Cristianisima de que separaron a Sicilia y Nápoles, y sólo desde que hicieron propios los señores Reyes de Castilla los intereses de Aragón con la unión de ambas coronas se propagó entre los castellanos la oposición de la Fraricia, hereditaria de los aragoneses...por to que siendo natural el odio de Aragón y Francia, y accidental solamente el de Francia y Castilla, era más facil conformar estos dos pueblos que aquellos, y por lo mismo más en Castilla que en Aragón encontraron acogida favorable las sugestiones de los ministros franceses a ravor del Señor Felipe $V$ ” 
epílogo de 1700 parecía anunciarse desde el mismo momento en que la sucesión del trono se configura como problema: «Con que encontrándose en la era del señor Carlos II sumamente arruinados los pueblos de Castilla, y muy favorecidos con sus exenciones los de Aragón, era preciso que en la esterilidad del tronco deseasen en él los primeros quien les aliviase de los impuestos, y los segundos quien les observase inviolables sus leyes. $Y$ como por un parte se persuadiesen en Castilla de una segurísima paz si recaía la Corona en el señor Felipe $V$, y en consecuencia de ella ciertísima exoneración de los tributos, y por otra parte constituía en Aragón un golpe mortal para sus fueros la demostración de un príncipe que ya no los respetase como fronterizos, aplaudieron los castellanos el nombramiento del sucesor y los aragoneses lo sintieron» 119 .

El repaso, en este sentido, ya permitía al autor extraer una primera referencia con la que situar el verdadero alcance, en materia de composición interna y orden constitucional, del debate generado por la adscripción del cetro real hispano: desvelaba la polarización de los discursos castellano y aragonés en torno a conceptos tan dispares como tributos y leyes. Presupuestos difícilmente conciliables, la historia servía a Robres para clarificar el contexto y aislar las materias, impuestos y fueros, que marcaban la agenda y prefiguraban la entidad de la polémica en su dimensión más propiamente hispana. Pero también, y dando un paso al frente, el recorrido le proporcionaba la base desde la que conducir el relato hasta uno de los puntos fuertes de su exposición: subrayar la trascendencia que para esa confrontación secular y ahora reactivada entre Aragón y Castilla encerraba

(Conde de Rorres, Guerras civiles, págs. 29/30). Con un predicadio ciertamente similar al que luego soporta el discurso de Benito Jerónimo Feijoo (y cfr., FElJoo, Antipatía, págs. 168/169), la aplicación del argumento a la cuestión sucesoria es lo que, a diferencia del talante de las Narraciones de Francisco de Castellví (CASTELlVi, Narraciones históricas, 1, págs. 61/63), con intención evidente se pierde en las páginas de un Teatro Crítico que, pese a incorporar esas distinciones territoriales e incluso anteponerlas a las diferencias dinásticas, se revelaba más interesado en promover y sustanciar la restauración de la "afectuosa confraternidad de españoles y franceses", la "estrecha unión y amistad entre España y Francia que se continuó en los tiempos hasta que sucedió en esta Corona la Casa de Austria", al modo propuesto ya en 1707 con acusados tonos dinásticos por Tomas de Puga y Rojas (Crisol de la española lealtad, págs. 196/97) y desarrollado poco despıés por Jacinto de Aranaz (Phelipe $V$, págs. 541/47) y José Antonio Ibáñez de la Renteria (Ensayo de vaticinios reales, págs. $87 / 88$ ) en el seno de un claro debate frente a los textos que como la Alegación jurídica de Alejandro de Herrera se manejan con premisas bien divergentes -- «este arnor, esta unión y iecíproca correspondencia, querer introducirla entre castellanos y franceses ist nigrum de albere; notable antipatia observa el orbe en estas dos naciones y soberanas monarquías" - y así alcanzan conclusiones no menos dispares: "diferente moneda corrió siemore entre españoles y austriacos: todo era unión, todo simpatía y todo amor. Las causas se hicieron comunes así como era una misma la Casa" (HERRERA, Alegación jurídica, págs. 56 y 58 ).

119 CONDE de ROBres, Guerras Civiles, pág. 28. 
la comparecencia de dos instancias dinásticas con pretensiones de asumir la Corona de Carlos II. Ese era el cuadro que interesaba pintar a unas Memorias, el juego y el combate cruzado entre naciones y dinastías que se abre en latitudes hispanas y no el de una repartición que se dilucida en las Cortes europeas, el de una lógica dinástica que navegando con el viento a favor por la ausencia de una asamblea de estados que representase la iurisdictio superior y la propia entidad del territorio descarta por principio cualquier comprensión propiamente constitucional del reino como garante de los códigos rectores en la sucesión de la dignitas y así recluye el asunto en los dominios privativos de los derechos dinásticos.

Entre unas anónimas Consideraciones desinteresadas sobre el proyecto y tratado concluido para la división de la Monarquía de España, que descalifican la repartición por «injuriosa a la sagrada independencia de los Reyes y opuesta a la natural libertad de los Reinos", y unas Reflexiones sobre el Tratado, que cargan las tintas contra la "despotiquéz con que los autores de este tratado pretenden disponer de los dominios ajenos y destinarles dueños a su arbitrio" ${ }^{120}$, piezas todas que asumen la sombra de la monarquía universal como motivo y materia y así enlazan argumentalmente con la más reciente literatura interesada en la figuración despótica del orden político francés que tanta difusión alcanza en el universo catalán del ocaso del Seiscientos ${ }^{121}$, en los territorios de la Corona de Aragón habían comparecido ya pronunciamientos tempranos y elocuentes sobre la cuestión que no parecían necesarios retomar a la altura de 1707, aun cuando el repudio de las facultades de disposición que se arrogan los principales cen-

120 Cfr., Consideraciones desinteresadas sobre el proyecto y tratado concluido para la división de la Monarquía de España. Barcelona, Imprenta de Comellas, 1700 - la cita en pág. 3- y Reflexiones sobre el Tratado que han concluido entre si los dos Reyes de Francia e Inglaterra, y los Estados Generales de las Provincias Unidas del País Bajo en el gran propósito de la sucesión del Rey Católico y repartición de su Monarquía. Barcelona, Imprenta de Cormellas, 1700 -la cita en pág. 3-

$121 \mathrm{Cfr}$, como muestra, Informe de verdaderas noticias per lo maior benefici, quiefut y gloria de Catalunya (BC. F.Bon. 4655bis) y Suspiros de la Francia esclava que aspira a ponerse en libertad, Barcelona, Joseph Llopis, s.a (BC.F.Bon.. 9468), cuya insistencia sobre «la potencia despótica y el poder arbitrario, absoluto y sin límites que se arrogan los Reyes de Francia" - (Suspiros. pág. 33) - se conjuga y ejemplifica con referencias al devenir político y constitucional de territorios como el Fosellón - donde según reza el Informe (p. 8) «de Constitucions de Catalunya no sen parla, los usos y usatges no estan en us, les privilegis de la patria abolits, no tenen deputats, cidors, justicias, magistrats, tribunals ni altre cosa humana quels defende de la voluntat del Rey, que alli es la única Hey»-- en una línea que luego precisamente asumen y acentúan textos como las Consideraciones o las Retiexiones subre el Tratado (y cfr., pág. 3: “tampoco se hace la más mínima expresión de que cuando el caso llegue les serán por los nuevos dueños religiosamente observados sus antiguos estilos y costumbres, sus privilegios y exenciones, sus patrias leyes y libertades"). Para el contexto de esta literatura, cfr., AlBAREDA, J., «L'impacte de la guerra dels Nou Anys a Catalunya. L'ocupació francesa de 1697", Afers, 20 (1995), págs. $29 / 46$. 
tros neurálgicos de la cartografía política europea sobre la corona hispana en la encrucijada del cambio de siglo termina por convertirse en un lugar común de la literatura política de la guerra civil en cualquiera de sus variantes dinásticas ${ }^{122}$. Lo que centraba la atención del Conde de Robres en su desarrollo expositivo no era tanto la propia resolución del combate cruzado entre dinastías y naciones sino una cuestión de procedimiento constitucional que se figuraba como determinante en la sustanciación del expediente: el monopolio de la representación que Castilla se arroga en el conjunto del proceso. Primeramente, en los prolegómenos de la redacción del testamento de Carlos II, a través de un "Consejo de Estado todo castellano", cuya incidencia sobre la conciencia del monarca se decia decisiva. Y a continuación, tras su aplicación, por la sesgada condición representativa de la Junta Universal encargada de guiar los designios de la monarquía hasta la llegada de Felipe de Anjou, pues «bien podía decirse que el nombramiento de la Junta universal de gobierno comunicaba al Condestable en la función a que era destinada toda la representación de la monarquía, y como este señor era todo castellano, y los que lo eligieron lo eran también, más que al todo representaba a Castilla», razón por la cual "se achacó en Aragón a que Castilla sola quería absorber en este gran caso toda la autoridad española, haciéndose conocer al nuevo Rey, no solamente por la nación preeminente como la Corte de los Reyes, sino también como la dominante y a las demás como súbditas» ${ }^{123}$.

De nuevo las concepciones de la nación y su representación armaban el discurso. Al igual que la negación de los supuestos de fondo que informan la ratio de la nueva planta, el repudio de la fórmula y procedimiento constitucional con que se ventila la cuestión sucesoria se fundamentaba sobre el trípode intelectual que conforman una comprensión de la naturaleza de la capacidad política de la nación, una percepción de la forma en que materialmente había quedado representada esa nación, y la trascendencia capital que al principio y la arquitectura de dicha representación había de

122 Cfr., las letras borbónicas de Jacinto de Aranaz, con su remisión a Pelayo y la "restauración de España" como momento de gestación de la "ley fundamental que establece la indivisión e integridad de la Monarquía" (Aranaz, Phelipe $V$, págs. 128 y ss), o el enunciado austracista de la Paz Octaviana, Barcelona, Rafael Figueró, 1707, cuyas ácidas referencias a un sector de “conternplativos", intermedio en el episodio de la repartición y en el más genérico de la sucesión entre unos "imperiales" dichos "amantes de la Patria" y otros "abiertamente apasionados por la Francia", enlaza además con el predicado de las Reflexiones sobre el Tratado (págs. 34 y ss).

123 CONDE DE ROBfies, Guerras Civiles, págs. 30 y 35. Tampoco la recapitulación de Francisco de Castellvi omite idénticas precisiones y prevenciones. Sin más, no duda en afirmar que «el poder que se arrogó el Consejo de Estado decidiendo sobre este grande hecho fue una notoria infracción de los fueros de los reinos" (CASTELLVi, Narraciones históricas, 1, pág. 136). 
concederse en la evaluación del episodio. La absorción de toda la representación política que se imputaba a Castilla, teniendo siempre presente la magnitud sucesoria de la operación constitucional para la que ésta se requería, no sólo suponía una anulación de la capacidad de articulación representativa de otras naciones sino que afectaba además de raíz al entendimiento compuesto del propio sujeto representado con el que se venía manejando aquella cultura política aragonesa que informa el discurso de Robres. La Junta en la que éste pensaba, y el senado que según propugnan sus Memorias hubiera debido dilucidar la nominación del nuevo monarca, resultaban ser de composición territorialmente compleja porque lo era también, desde su punto de vista, la España que entendian representar. Una vez más el sello político y constitucional que imprimía entidad y sustancia a la impugnación filtraba sus credenciales, interpretando tanto la formación como el desenvolvimiento histórico de la nación, y las naciones que la componen, de una manera que presuponía el reconocimiento de unas capacidades políticas. La razón histórica, por esta vía, también se implicaba decididamente en el debate. $Y$ con ella la posibilidad de contemplar una vía alternativa frente a la solución arbitrada en clave castellana a la encrucijada de 1700 . Una fórmula y procedimiento de nominación y determinación de la cabeza por parte del cuerpo político, de la representación del regnum, más concordante con lo que se podía tener por histórico: la del Compromiso de Caspe, modelo invocado en las Memorias en cuanto precedente de un interregno durante el cual "había residido el universal gobierno de la Corona de Aragón en los parlamentos de las provincias, y el particular de cada una en el Justicia de Aragón y en los Regentes del oficio de la gobernación general que solos ejercen la jurisdicción ordinaria» ${ }^{124}$.

Las implicaciones de naturaleza constitucional contenidas en la recuperación del modelo de Caspe eran evidentemente de orden mayor. Su pretendida instrumentalización significaba ante todo, tal y como las $\mathrm{Me}$ morias se ocupaban de recordarlo, «negar al difunto Rey la potestad de la

124 Conde de Rogres, Guerras civiles, págs. 32/33, de donde también proceden las citas siguientes. Y cfr., también, CAstellvi, Narraciones históricas, I, pág. 137, donde se recogen las palabras del Conde de Frigiliana, quien tras reconocer en el seno del Consejo de Estado que "ni los derechos de los austriacos ni los de los borbones eran tan claros que no estuviesen embarazados de muchas dudas y litigios" apunta "que no se debia de olvidar el Congreso de Caspe, en que los jueces diputados dieron Rey á Aragón». Y sobre el entendimiento inverso desde el que se convoca la imagen del episodio en el contexto de 1640, menos interesado en la cuestión de procedimiento que en la resolución del proceso, cfr., el Manifiesto de fidelidad catalana, integridad francesa y perversidad enemiga de la justa conservación de Cataluña con Francia de 1646 (BC.F.Bon., 147), en cuyo cuerpo se rememora "la injusta declaración de Caspe que en odio de los catalanes les sujetó a Castilla” (Manifiesto, pág. 40). 
institución del heredero y poner en duda el derecho del sucesor". Asumir el Compromiso como fórmula de sustanciar la encrucijada sucesoria suponía por tanto una radical afirmación y extensión de ciertos principios fundamentales que resultan ser códigos definitorios de una específica cultura política: por un lado, la centralidad del propio entendimiento del territorio en clave de universitas perfecta y soberana que subyacía en el conjunto de la exposición de las Memorias, con la condición de elemento esencial que se supone para la constitución territorial y la posición intermedia entre el rey y el reino que recae sobre una asamblea de estados que se decían parlamentos. Y por otro, la vigencia y defensa de toda una concreta representación del orden interno de la monarquía, de su carácter agregativo tradicional, frente a las pretensiones - que en el momento se detectan - tendentes a reinterpretarlo sobre la base de una diferente relación entre la cabeza y los miembros. En esos precisos términos se había promovido la inmersión en el modelo de Caspe: "como sin duda desde la muerte del señor Carlos II hasta que el señor Felipe $V$ aceptó su testamento hubo interregno...así hubo en Aragón quienes regulándose en todo con los sucesos de la muerte del señor Martín solicitaron el que los Diputados del reino, como cabeza de la Corona, promoviesen con embajadas la Junta general de toda ella para tratar los intereses comunes". La traumática suerte de esa iniciativa, neutralizada por las instancias reales operativas en los territorios forales, bien podía ejemplificar en el relato de Robres la inmediata desventura de toda una cultura y proporcionar así el cierre a toda su construcción argumental.

Desde posiciones de implicación dinástica bien evidentes ya se habia procedido a deslegitimar la resolución del proceso sucesorio por la omisión y marginación de unos órganos representativos y fundamentalmente de unas Cortes. En su Manifiesto publicado en 1703 en favor de los iura del Archiduque, y dirigido a la nación española, Gottfried Wilhelm Leibniz apuntaba directamente en esa dirección: «La voluntad de las naciones no se expresa por los magistrados o regentes, sino por las Asambleas de Estado de los reinos y provincias. Sería preciso, pues, que quienes se habían erigido en regentes convocaran las llamadas Cortes o Estados, tanto en Castilla como en Aragón, antes de tomar el más mínimo acuerdo acerca de la sucesión» ${ }^{125}$. Aun cuando sólo fuera para formalizar el juramento del monarca, desde ciertos ámbitos intelectuales castellanos, como el que pudiera representar el Marqués de Villena, y desde ciertos centros neurálgicos

125 Leibniz, Manifiesto, págs. 291/323, y cfr., Viejo Yharrassarry, J., “Domingo de Aguirre: la defensa de una constitución de libertades», Mundo hispánico, II, 1343/1348. 
de su tejido político, como el que pudiera significar el Consejo de Estado, la convocatoria de las Cortes también se había constituido en motivo y reclamación recurrente durante el conjunto del episodio sucesorio. Los supuestos de fondo de orden político y constitucional que informan la centralidad del hecho asambleario en el discurso de Robres nada tenían que ver $\sin$ embargo con aquellas llamadas de atención sobre la postergación de unas Cortes cursadas en Castilla o apuntadas desde los círculos imperiales. El Manifiesto de Leibniz era pieza genuina de una literatura dinástica de naturaleza política. Promovía una doble identificación dinástica y una línea de demarcación política dentro de la encrucijada sucesoria: la equiparación de la Casa de Borbón con una forma dominio dicho despótico por eversivo para una constitución de libertades, con conversión del reino en mera propiedad dinástica y afirmación del monarca como autócrata patrimonial; y la vinculación consustancial de la Casa de Austria con un modelo de dominio político por sujeto a derecho. Entraban así en su discurso unas libertades. Pero siempre, y a diferencia de las Memorias de Robres, al servicio de la interesada fijación del mapa genético que codifica la dispar naturaleza política de unas Casas. Libertades que son derechos cuyos sujetos resultaban ser la Iglesia, los estados o los territorios pero cuya vigencia así se vinculaba primera y fundamentalmente con la posición y disposición de un monarca, perdiendo la valencia por la que pudieran portar toda una identidad política territorial. Una identidad política que tampoco encontraba un campo abonado para su afirmación en Castilla, donde precisamente en estos momentos venía arrogándose el Consejo de Estado el papel parlamentario que desde Aragón se solicitaba para las Cortes.

Ese es, en cierto modo y manera, el reproche que con mayor acritud encara el Apologético de España contra Francia, publicado en Barcelona en 1704, a un previo Desengaño de ignorantes y remedio de apasionados: promover y promulgar que "los Consejos representan a la Monarquía" como predicado político de legitimidad dinástica. Interpone ya el Apologético una noción y concepción de la naturaleza política de los Consejos categóricamente distinta: "Una cosa es la Monarquía o Reino, y otra los Consejos: estos son los Ministros del Rey; y el Rey y sus Ministros se distinguen en la República o Monarquía, como la Cabeza se distingue del Cuerpo: no tienen más autoridad los Ministros que la que el Rey les da para que le ayuden en el gobierno" ${ }^{126}$. Pero sobre todo, con indudable

126 Apologético de España contra Francia, Barcelona, Rafael Figueró, 1704, pág. 9. Para los diferentes matices nada irrelevantes que entre el Desengaño y el Apologético venian cifrando el 
sutileza y hondura política, lo que su anónimo autor detecta como sustrato de la situación antinatural de la guerra civil es una perversión y desajuste constitucional que recorre el momento crucial de la sucesión: «En el tiempo que se habla, no había Consejos, ni Ministros del Rey, porque desde que espiró Carlos II...espiró toda su autoridad y jurisdicción; y consiguientemente la de todos sus Ministros, por lo cual todo el poder y autoridad que el rey tiene participado de la República para gobernar, por su muerte se devolvió a su fuente y origen, que es la misma República» ${ }^{127}$. Sabida y bien sabida, detallada y categóricamente rememorada desde Cataluña con motivo de la jurisdicción virreinal en el umbral de la coronación de Felipe de Anjou ${ }^{128}$, la letra y espíritu de una clave tan esencial del ordenamiento foral servía al Apologético para desplegar y asentar con mayor firmeza el motivo que domina su argumentación: la noción del Reino en Cortes, en cuya posición constitucional detectaba el fundamento político que convertía el mandato de Felipe de Anjou en un mero gobierno de facto y no de iure. Recitar que la "potestad" en materia sucesoria "reside privativamente en el Reino en Cortes", suponía además trazar una nítida demarcación entre el lenguaje constitucional catalán y el discurso desnudamente dinástico a favor del Archiduque por mucho que ambos navegaran en idéntica dirección. El supuesto del Reino en Cortes también comparece en aquel yacimiento textual que tan bien representa y retrata la Alegación jurídica de Alejandro de Herrera: «Sobre injusto e incivil, fue inútil el reconocimiento de los pueblos a Felipe de Anjou. Fue particular y

entendimiento propiamente castellano de la cuestión, cfr., la forma más elabora de penetración en el asunto que en la época se hace pública particularmente a través de los comentarios de Pedro de Portocarrero en su Teatro Monárquico de España, Madrid, Juan Garcia Infançon, 1700 (que cito por la edición de Carmen Sanz Ayán, Madrid, Centro de Estudios Políticos y Constitucionales, 1998), págs. $141,224 / 32$ y 452. Aislados previamente del entramado corporativo de cuerpos y estados, e incorporando una mención especial paia el Consejo de Estado y el de Castilla, que se predican como "columnas fuertes de la Monarquia" con significativa omisión de unas Cortes y elocuente equiparación con un "político senado veneciano", la presentación de unos Consejos como "instrumentos por donde la suma potestad ejecuta su imperio", instancias así que "usan del poder comunicado y participado del Príncipe", se superpone en las páginas del Teatro con la oportuna referencia sobre la "gran prudencia" que en materia de gobierno supone "seguir el Príncipe el parecer de los Consejos". Así Portocarrero no sólo lograba acomodar los consejos en el cuadro de la política, por comunicación de la suprema potestad civil. También, y ante todo, les reconocía y asignaba una trascendental capacidad para incidir, mediante la conformación de la prudencia, en su determinación más profunda.

127 Apologético de España, pág. 9.

128 Cfr., CAStellví, Narraciones históricas, I, págs. 237/251, Feliu DE LA PENA, Anales, III, págs. 461/477. Para la reconstrucción más detallada del episodio, cfr., ALBAREDA, J., La guerra de successió i Íonze de setembre. Barcelona, Empúries, 2000, págs. 35 y ss.; Torras I RiBE, J.M., La guerra de Succesió i els setges de Barcelona (1697-1714). Barcelona, Rafael Dalmau, 1999, págs. 47 y ss, y Alabrús, Feiip $V$, págs. 90 y ss. 
no común. Fue de algunos y no de todos. $Y$ para ser legal el reconocimiento de los pueblos no debe ser particular, debe ser universal, pues esta forma dio la ley antigua de los Godos en España..Y de aquí nació la costumbre general de toda la España de reconocer y jurar los Reyes en Cortes públicas por los tres estados del reino, porque en ellos se representa todo el Reino». Este género de literatura podía incluso encumbrar el asunto hasta la categoría dogmática: "la razón es porque en este reconocimiento son mutuos los juramentos; de los pueblos jurando fidelidad al príncipe, y del Rey jurando a los Pueblos conservarlos en Paz y justicia, y guardarles las leyes y costumbres del Reino" ${ }^{129}$. Pero la concordancia entre el Apologético y la Alegación, por poner nombres propios a vetas discursivas distintas, el acuerdo básico que los enfrentaba con aquel dictado borbónico que resume y asienta el Phelipe $V$ de Jacinto de Aranaz ${ }^{130}$, no iba más allá. Lo impedía el preciso entendimiento político de la republica del reino con el que opera en todo momento el Apologético y cuyo rastro se pierde en la Alegación.

Si bien conduce la materia hasta su punto de ebullición - «la más corriente y común opinión de los juristas y teólogos es que si el Reino esta vacante el legítimo y competente juez son los estados del reino en Cortes Generales"- Alejandro de Herrera no dudaba después en rematarla con supuestos de implicación dinástica evidentes: "Más esta opinión, con ser verdadera, no se puede aplicar al caso presente. Primero porque sólo pro-

\footnotetext{
129 Alejandro DE HeRRERA, Alegación jurídica, págs. 256/58.

130 «Es desconcierto de la razón echar de menos las Cortes a vista del llamamiento y aclamación común de Reinos y Ciudades, porque siendo principio cierto que en los Reinos y repúblicas unidas políticamente la potestad gubernativa es Derecho divino y natural, y que las cortes las instituyen, y como representaciones y vicegerentes suyos los Reinos y Repúblicas, echar de menos las Cortes a vista del consentimiento universal de los Reinos y Ciudades es apreciar más el subtitulo que el principal, y aun querer que pueda más el principal que el subtitulo", ARANAZ, Phelipe V, pág. 169. Y cfr., como contrapunto, Apologético, pág. 7: "Decir que el Reino ha recibido y jurado al rey es evidentemente falso, porque no se ha convocado ni juntado para ello en la forma que basta para llamarse Reino en Cortes. Y sólo es verdad que la Junta que nombró Carlos Segundo introdujo al de Anjou a la Corona, y después de introducido llamó y apremió a las Ciudades a que fuesen a Madrid a reconocerle $v$ jurarle, $y$ en efecto fueron y en Atocha cada Ciudad de por si le reconoció y juró, y lo mismo hicieron los Nobles y Cabildos de las Catedrales, cada cual en su Iglesia. Este es el hecho de la verdad: pero ¿ esto que tiene que ver con el Reino junto en Cortes? Todas las Ciudades. Nobles y Cabildos son partes materiales del reino, pero lo formal de él consiste en que todas sus partes y miemibros estén convocados y juntos en uno, lo cual no se ha ejecutado, ni aún ruando se ejecutase, después de introducido, sería de valor alguno por defecto de libertad....consiguientemente el dicho juramento y recibimiento es ipso iure nulo, como obrado por quierı no es parte legitima para hacerle, debiéndose entender lo mismo aunque el Reino en forma lo hubiese jurado y reconocido después de introducido en la Corona, por el mismo defecto de libertád".
} 
cede cuando faltan todos los parientes del Rey, y aún en la serenísima Casa de Austria dura la sangre española. Y segundo, porque aún era vivo Carlos II y no podía los estados por sí solos declarar sucesor" ${ }^{131}$. Una Alegación cerradamente dinástica podía así terminar mostrando un mayor parentesco y filiación conceptual con el Phelipe $V$ de Jacinto de Aranaz - también dispuesto a reconocer «que en caso de controversia o duda de a quien pertenece la Corona el reino es el legítimo intérprete", e igualmente presto a negar la concurrencia de esa precisa circunstancia en el episodio sucesorio hispano del momento inaugural del setecientos- que con la cruzada política y constitucional de un Apologético interesado en asentar "que el poder que el Reino o República da y refunde en los Reyes es en orden a gobernar lo político y militar, esto es, para mantener a todos sus naturales en justicia y equidad, pero nunca les ha dado, ni les puede dar autoridad para elegir sucesor, porque si esta autoridad cediera la república fuera tan perjudicial al bien común que dejara de ser república y se hiciera una multitud de hombres esclavos y serviles" ${ }^{132}$. Al menos, entre concebir como concibe el Apologético que «el fundador del mayorazgo de la sucesión a la Corona de España es el Reino", entre proclamar que la potestad privativa en la materia residía en un Reino en Cortes así garante de los códigos rectores de en la sucesión de la dignidad real, y recitar, como recita la Alegación jurídica de Alejandro de Herrera, que «el pueblo no reasume el poder soberano de la majestad sino faltando toda la sangre de la Casa Real", mediaba un buen puñado de grados en las coordenadas culturales de la cartografía política del tiempo ${ }^{133}$. Y es esa tan variada gama de semánticas políticas y constitucionales, esa acusada comparecencia de matices nada irrelevantes que impide remitir y acomodar desnudamente la compleja literatura política de la guerra civil sobre dos únicos moldes procedentes de la fragua dinástica, la que en definitiva enriquece el Conde de Robres con sus Memorias. Con su llamada en causa, en la interiorización de la nueva planta, de las formas de representación del regnum y la posición constitucional de las Cortes procedía a la apertura de todo un espacio de pensamiento formalmente enmarcado por el protagonismo que confiere a las naciones y, dando un paso más, esencialmente definido por la mera escritura desde convicciones y posiciones personales y familiares de filiación borbónica que le condenan a la

\footnotetext{
131 Alejandro de Herfiera, Alegación juridica, pág. 216.

132. Jacinto de Aranaz, Phelipe $V$, págs. 174/77 y Apologético de España, pág. 5.

133 Alejandro de HerRera, Alegación juridica, pág. 251; Jacinto de Aranaz, Phelipe V, pág. 178 y Apologético, págs. 4 y 8 .
} 
confiscación de sus bienes en la Cataluña que proclama en Cortes a Carlos III pero que no le impiden armar un discurso cuya urdimbre conceptual, sin por ello rebajar su acusada personalidad, manifiesta una mayor sintonía con el anónimo Apologético y las Narraciones de Castellví que con el Phelipe $V$ de Jacinto de Aranaz o con aquellos Ensayos de lbáñez de la Renteria que descubren en Felipe $V$ un «nuevo Salomón» y en Almansa una "nuevamente resucitada España» 134.

Nieto de un regente del Consejo de Aragón que en la crisis de 1640 se compromete abiertamente con la posición de Felipe IV, formado y curtido en los códigos cardinales de la cultura constitucional del universo aragonés con una participación política activa simbolizada por su nominación como representante de la Diputación catalana ante Felipe V en $1701^{135}$, el Conde de Robres cimentaba la composición de sus Memorias sobre un genuino sustrato de comprensión política. El mismo sustrato que podía aflorar con notable naturalidad en el lenguaje del Emperador político y política de Emperadores que Francisco Solanes dedica en 1706 a Carlos III. Trenzado sobre supuestos de fondo que se apuntan y despuntan en su recurrente apelación a las "costumbres y leyes de la Patria", en su precavida puntualización sobre las «muchas dificultades que encierra el introducir alguna Constitución contra la Costumbre", o en su asentado convencimiento sobre clos muchos tumultos que suele causar en una República la mutación de sus Leyes Patrias", la semántica del Emperador político era tan familiar a las Memorias como incompatible con las menciones a «l'alcoran de los fueros» o los designios de "aboullir leurs extravagantes privileges" que las figuras más relevantes de la inteligencia borbónica emplean al escrutar el perfil y las implicaciones de la guerra civil ${ }^{136}$. Ahora bien, preocupadas en todo momento por calibrar el alcance y aquilatar el sentido de unas amenazantes prevenciones castellanas frente al ordenamiento foral que en fecha tan significativa como la de 1700 el Teatro Monárquico de Pedro de Portocarrero se ocupa de actualizar ${ }^{137}$, las Memorias

134 IBÁÑEZ DE LA RENTERIA, Ensayos de vaticinios reales, págs. 79, 131/142 y 183.

135 Sobre Bernabé Pons de Mendoza, à quien sustituye Rafael Villosa como regente del Consejo de Aragón, cfr., ARRIETA, J., «Derecho e historia en ambiente postbélico: las "Dissertationes" de Rafael Vilosa (1647)", páç. 184, y para el nombrarnierto del Conde de Robres como representante de la Diputación, cfr., Feliu DE LA PEÑA, Anales de Cataluña, III, pág. 483; Castellví, Narraciones históricas, I, págs. 264 y 279, y Beıando, Historia Civil, I, pág. 84.

136 Cfr., Francisco SolANES, El Emperador político y política de Emperadores, III, Barcelona, Joseph Llopis, 1706, páizs. 16/22, y las cartas de Tobias de Bourck al Marqués de Torcy, de 30 de septiembre de 1705 y 6 de junio de 1707 (AAE. CP(E), vol. 151, fol. 173 y vol. 168, fol. 213)

137 Pedro DE Portocarrero, Tetaro Monárquico, págs. 219/220: «si las provincias o reinos han faltado a la obediencia de sus naturales señores, tomando las armas con pretexto de haber- 
tampoco asumían la semántica patriótica propia del republicanismo clásico con la que Francisco Solanes presenta en sociedad a la altura de 1700 la primera entrega de su Emperador político y que luego retoman y desarrollan el Crisol de la fidelidad o la Lealtad catalana en el tramo final de la contienda civil. Solanes, sobre el mismo panegírico de Trajano compuesto por Plinio que luego sirve a lbáñez de la Renteria para iluminar con fulgor profético la figura de Felipe $V^{138}$, procedía a una declinación patriótica de la política que asume la forma y los contenidos de la ética y así concibe una educación moral como preludio de otra propiamente política. Con la rectitud moral como requisito fundamental y fundacional de la vida política, sus máximas cívicas - «todos los intereses de los particulares están vinculados en la utilidad e interés de la Patria como en su origen, todo lo que tiene resabios de provecho de la Patria, esto mismo es utilidad de los Ciudadanos»- y sus metáforas constitucionales — «arquitectura política es la república: la Patria es la cabeza, los miembros son los Ciudadanos, si al peligro de aquella no acuden éstos, será difunto cadáver toda la vida política»- patrióticamente se conjugan eliminando cualquier frontera y demarcación entre el gobierno de uno mismo y el gobierno de la república:

«Practiquemos ésta política: la República, por sí sola, como cosa inanimada, no puede resguardarse de la poderosa violencia de sus enemigos. Si los Ciudadanos encendidos del ardiente volcán del amor a la $\mathrm{Pa}$ tria no la defienden, quedará expuesta ser miserable despojo de las iras de sus contrarios. Si el gobierno de una plaza o ciudad se reviste de la caridad de la patria, ni dudará en defenderla hasta el último aliento, ni se arrastrará a los cautelosos conciertos de una traición alevosa. Si el Capitán General leva por timón de su gobierno el amor de la Patria, anhelará las ocasiones de derrotar a sus enemigos. Si los Ciudadanos fomentan en sus pechos el afecto que deben a la Patria soportarán alegres los tributos y pechos que su dueño les impone. Si el Ministro, si el Consejero de Estado, tienen por blanco siempre la caridad de la Patria conseguirá en sus consultas lo mejor a su Monarca. Si el Presidente, que con ambicioso anhelo aspira a la dignidad o el puesto, tuviese la mira en el amor a la Patria tal vez no procuraria adelantar sus intereses a trueque de los de aquella. Y finalmente, si el Monarca, si el Príncipe tomase por báculo la caridad de la Patria, asistiría con más deseo y vigilancia a las ocupaciones de su Patria" ${ }^{132}$.

les quebrantado sus libertades, y se viere el Principe obligado a desenvainar su espada para reducirlos a su antigua obediencia, mal hará cuando lo consiga en dejarlos con sus antiguos privilegios, porque por derecho han decaído de ellos y no tiene el Príncipe obligación a reintegrarlos".

138 IBÁNEZ DE LA RENTERIA, págs. $2 / 3$ y 24.

139 Francisco Solanes, Emperador Poiitico, I (Barcelona, Jseph Llopis, 1700), págs. 14/27. 
En un contexto de composición dominado por la salvaguarda del tradicional orden constitucional del territorio frente a las turbulencias dinásticas, en un contexto que le es propio y bien conocido por su participación política activa, Francisco Solanes mantenía viva la llama de una semántica largamente cultivada en latitudes aragonesas que permanece latente durante el conflicto civil y emerge ya decididamente en la literatura política catalana que procesa la encrucijada planteada por la nominación imperial del Archiduque. Entonces, en el entorno de 1713, la convocatoria cursada por Solanes para "hacer una República durable", y que pasaba primera y primordialmente por «anteponer el público interés de su amada libertad a todos los intereses particulares", se convierte en el motivo capital de un aluvión de textos en los que los ecos del lenguaje patriótico del republicanismo clásico resuenan con una intensidad desconocida en el universo hispano. Era aquel un momento y un posicionamiento en el que las alabanzas del vivere libero y la proclama pro patria mori adquieren un sentido y protagonismo del que en cierto modo podían todavía carecer en 1707 y que desde luego no rige la lectura de la guerra civil y su derivación bajo forma de nueva planta que maneja el Conde de Robres ${ }^{140}$. Al fin y al cabo el Conde de Robres madura la opción de la redacción de unas Memorias en el tiempo y en las coordenadas culturales sobre las que se sitúa José Sisón Ferrer cuando escribe desde Zaragoza a José Grimaldo para anotar primero que «un decreto que no deja piedra sobre piedra en Aragón, ni deja clase, estado ni individuo a quien no alcance en lo jurídico, político y económico, y una mutación tan súbita, en unos naturales que se han criado siempre con que sus Leyes precedieron a sus Reyes, no puede dejar de consternarlos y de infundirles muy extrañas sensaciones", y para confesar y anticipar después que esos mismos naturales "atribuyen el decreto más al odio antiguo con que los castellanos siempre han mirado este reino, que no a la voluntad del Rey Nro. Señor» ${ }^{141}$.

Desde luego era un tiempo de frontera en el que se exploran variantes de signo bien diverso. En su intervención política frente a la silueta territorial de la nueva planta José Manuel Miñana pinta por esas fechas un pai-

140 Cfr., por ejemplares, tanto la Lealtad catalana, págs. 46 y ss., como el Despertador de Catalunya. Barcelona, Rafael Figuero, 1713 (que consulto por el tomo 1 de los Escrits politics del segle XVIII editados por J. A.lbareda --Vic, Eumo, 1996, págs. 121-192-), y las consideraciones sobre la materia de VIROLI, M., Por amor a la patria. Madrid, Acento, 1996, págs. 35/121, y Pocock, J.G.A., El momento maquiavélico. El pensamiento político florentino y la tradición republicana atlántica. Madrid, Tecnos, 2002, págs. 133 y ss.

141 Archivo Histórico Nacional (AHN), Estado, Ig. 320, carta de José Sisón a José Grimaldo, 11 de julio de 1707 . 
saje histórico poblado por "buenos ciudadanos abatidos por el terror» y "nobles que no tienen intención de cambiar de fidelidad, sino que más aún están dispuestos a defenderla con las armas". Enfrenta así a la nueva planta un cuadro de fidelidad y no una cultura constitucional: "en toda esta historia nada debe ser entregado a la posteridad tan diligentemente como los nombres de aquellos que, en absoluto corrompidos por este ataque de infidelidad, transmitieron a sus descendientes su lealtad intacta" ${ }^{142}$. Los jurados de Zaragoza, en un memorial de primeros de julio de 1707 , apelan también al lenguaje de la fidelidad pero centran con determinación el matiz y talante político de su discurso en la imposibilidad de proceder con naturalidad a la disolución de un ordenamiento tradicional mediante la implantación de un modelo alternativo diseñado sobre fundamentos territoriales y sensibilidades jurídicas que ciertamente resultaban ajenas: "No se niega que las leyes de Castilla sean buenas, pero también es innegable que en todos los reinos hay un genio predominante con que se distinguen los vecinos; y esta es la causa porque no se gobiernan por una ley todos, porque lo que se adapta para unos no se conforma para otros. Y así serán para los castellanos proporcionadas sus leyes, y para los aragoneses violentas" ${ }^{143}$. Comparten así los jurados semántica y abordaje de la materia con el Memorial José Ortí y no tanto con el De Bello Rustico de Miñana. Pero un terreno, sino de coincidencia, si de confluencia los vincula esencialmente: son todas piezas a las que anima idéntico espíritu y aspiración política de incidencia y modificación de los supuestos que rigen el perfil de la nueva planta. Todas y cada una de ellas se niegan y resisten a interiorizar y procesar sin más el nuevo orden jurídico y político decretado para el Continente de España. No habilitan cauces de comprensión en ese sentido porque todavía manejan claves y esperanzas, como la depositada en la economía de la gracia, en la figura piadosa y paternal del soberano, fundadas y fundamentadas sobre una comprensión tradicional y nada retórica de lo político. Tan solo unos meses después esas esperanzas sin embargo desaparecen. El lenguaje de la soberanía que captura la letra de los decretos de liquidación de la planta tradicional no requiere de más tiempo para mostrar su absoluta falta de porosidad frente a los argumentos de esa naturaleza. Las Memorias del Conde de Robres adquieren entonces su sentido. Arrasada la matriz de la que nacen el De Bello Rustico y los Memoriales, llega el momento de levantar acta y rendir cuenta, de meditar y reflexionar, sobre el conjunto de las implicaciones del episodio.

142 Miñana, De Bello Rustico Valentino, págs. 56,59 y 63.

143 AHN, Consejos, Ig. 18190, Memorial de la Ciudad de Zaragoza, 4 de julio de 1707. 
Perdidos unos derechos lo que se trataba era de evitar que también se perdiera una historia: la compleja historia del naufragio de aquellos derechos propios de unos territorios en las corrientes nacionales de las aguas dinásticas.

La del Conde de Robres se concebia por tanto, y en definitiva, como una lectura de la guerra civil desde el panorámico mirador de la nueva planta. Una lectura en lengua y cultura constitucional aragonesa, y así de difícil ajuste dinástico, que ante todo pretende y procura insinuar en tan específico contexto una singular senda interpretativa de la materia al no recluirse en los estrechos límites del modelo de reintegración que deriva del proceso de secesión que conoce una guerra de sucesión. Más que indagar un presente, un tiempo contemporáneo, y bucear en la genealogía de unos conceptos o la filología de unos textos, los que decretan la liquidación de una planta así ya antigua, las Memorias de Robres sugerían la inmersión y el reconocimiento de un pasado de concurrencia - no siempre pacífica- de identidades regnícolas. Unas Memorias lo que reclamaban e imponían era una memoria, la propiamente histórica, como esfera y laboratorio de procesamiento e interiorización que había necesariamente de visitarse para alcanzar la puntual comprensión, y dejar luego constancia, de la existencia de una base o trasfondo cultural sobre el que ahora se proyectaba la nueva planta. En cierto modo, y mediante la intencionada recuperación de una historia en clave aragonesa, extendiéndose entonces hacia el pasado para entender un presente, las Memorias terminaban convirtiendo así en puerto de arribada, en producto de la historia, lo que política y jurídicamente se predicaba como punto de partida. La lógica que anima su trama argumental, recuperar los nudos, los momentos privilegiados de trasparencia cultural que terminaban posibilitando el desenlace de 1707, apuntaba decididamente en ese sentido y respondía categóricamente a esa aspiración. Ampliando materias y diversificando sujetos, encrucijadas como la sucesoria de 1700 perdían su exclusivo carácter dinástico ante una mirada que con naturalidad no sólo descubría tensiones territoriales de fondo sino que las reconvertía en la problemática principal. Decisivo para la suerte de la constitución de unos reinos, determinante en la comprensión del origen y la naturaleza legal de los mismos, pues cabian distintas posibilidades en la titularidad de una cabeza de cuya unión con los miembros derivaba precisamente la naturaleza y condición de aquellos como cuerpo político, el momento sucesorio terminaba interesando y adquiriendo un renovado sentido, antes que por la colisión de derechos de unas Casas, por el encuentro y proyección de inquietudes e intereses regnicolas que se suscitan y dilucidan en un coritexto radicalmente nuevo de elección de un monarca. El par de decretos del verano de 1707 
perdía consecuentemente su ubicación en una historia dinástica, la de los Austrias y los Borbones, para encontrar acomodo con más propiedad en las interioridades y profundidades históricas de Hispania, en los vericuetos de su concepción y constitución tradicional.

III. Agustín López de Mendoza y Pons Pérez de Pomar y Salbà, III Conde de Robres, nacido en Barcelona y bautizado en su iglesia de Santa Maria del Mar el 25 de noviembre de 1668, muere en Sangarrén (Huesca) el día 26 de septiembre de $1720^{144}$. La gabeta que guarda las Memorias inicia entonces su particular periplo y peregrinación. Entre títulos y propiedades, María Josefa de Pons y Bornonville, hija única del matrimonio del Conde de Robres con María Ignacia de Bornonville y de Eril celebrado en la catedral de Barcelona el 16 de noviembre de 1700, recibe y custodia entonces el manuscrito. Por su enlace en Sangarren en 1715 con Buenaventura Pedro Abarca de Bolea Ximenez de Urrea la gabeta se incorpora luego a la rica biblioteca familiar que hereda en 1742 el $X$ Conde de Aranda, Pedro Pablo Abarca de Bolea Ximenez de Urrea. Desde ese momento y hasta agosto de 1851, cuando Antonio Ferrer del Río regala en Barcelona el manuscrito a Prospero Bofarull, el texto continua su itinerario alejado siempre de la tipografía. El propio Antonio Ferrer del Río minuciosamente lo relata y describe:

«Este libro, que es el original del mismo autor, y del cual no existe ninguna copia, perteneció al Conde de Aranda, nieto por parte de madre del conde de Robres. Muerto el Conde de Aranda quedó en poder de su viuda, que casó después con el Duque de Alagón. A la muerte de éste, se lo regaló dicha Señora a su amigo el Coronel de Guardias, D. Joaquín Morales. $Y$ a éste se lo compré yo en 1845 por una onza de oro" ${ }^{145}$.

Años después, cuando aquelia única copia manuscrita pasa de manos de Prospero Bofarull a las de Manuel de Bofarull, las Memorias encuentran finalmente un cauce editorial. Jefe del Archivo de la Corona de Aragón y promotor de la Biblioteca de autores aragoneses, Manuel de Bofarull encarga la preparación de una edición a Baldomero Mediano y la misma, que es la primera y única, se publica en Zaragoza en 1882. No parece arriesgado afirmar que la sede, el cuerpo de una Biblioteca de autores

144 Para los datos biográficos, cfí., MORENO MEYERHOFF, P., "Linajes catalanes en el Condado de Aranda: la Casa de Rupit (siglos xIV-xVIII)", en Ferrer BenImelLI, J.A. (dir.), Sarasa, E. y SERRANo, E. (coords.), El Conde de Aranda y su tiempo. Zaragoza, Institución Fernando el Católico, 2000, II, págs. 99/134

145 BC. Mss. 151. 
aragoneses, probablemente hubiera satisfecho al Conde de Robres. $Y$ tampoco parece dificil imaginar que la tan dilata espera no le hubiese proporcionado idéntica satisfacción, aunque el 15 de septiembre de 1715, cuando dicta su testamento en Sangarren ante los notarios Raimundo de Latre y Vicente de Santaolaria, ya podía intuir el difícil destino de su obra, pues no había comparecido todavía, significativamente, ninguna historia de las guerras civiles de España. 